(2) norden 



\section{Risk assessment of caffeine among children and adolescents in the Nordic countries}

Helle Margrete Meltzer, Tor Øystein Fotland, Jan Alexander, Elisabeth Elind, Helena Hallström, Henrik Rye Lam, Kirsi-Helena Liukkonen, Marta Axelstad Petersen, and Elisabeth Jona Solbergsdottir 
Risk assessment of caffeine among children and adolescents in the Nordic countries

TemaNord 2008:551

(C) Nordic Council of Ministers, Copenhagen 2008

ISBN 978-92-893-1731-3

Print: Ekspressen Tryk \& Kopicenter

Copies: 185

Printed on environmentally friendly paper

This publication can be ordered on www.norden.org/order. Other Nordic publications are available at www.norden.org/publications

Printed in Denmark

Nordic Council of Ministers

Store Strandstræde 18

DK-1255 Copenhagen K

Phone (+45) 33960200

Fax (+45) 33960202

www.norden.org

\section{Nordic Council}

Store Strandstræde 18

DK-1255 Copenhagen K

Phone (+45) 33960400

Fax (+45) 33111870

\section{Nordic co-operation}

Nordic cooperation is one of the world's most extensive forms of regional collaboration, involving Denmark, Finland, Iceland, Norway, Sweden, and three autonomous areas: the Faroe Islands, Greenland, and Åland.

Nordic cooperation has firm traditions in politics, the economy, and culture. It plays an important rol in European and international collaboration, and aims at creating a strong Nordic community in a strong Europe.

Nordic cooperation seeks to safeguard Nordic and regional interests and principles in the global community. Common Nordic values help the region solidify its position as one of the world's most innovative and competitive. 


\section{Content}

Preface

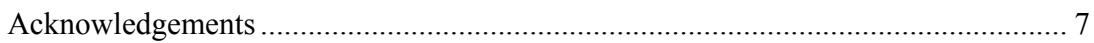

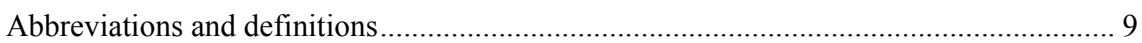

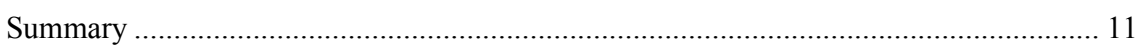

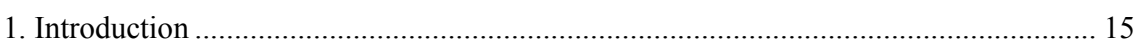

Current legislation on caffeine in foodstuffs in the Nordic countries.............. 15

2. Hazard identification and characterisation of caffeine ................................................ 19

2.1 Chemical structure and sources ...................................................................... 19

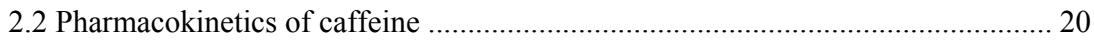

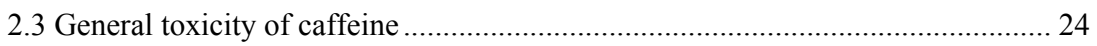

2.3.1 Molecular mechanisms of caffeine action .......................................... 24

2.3.2 General pharmacological effects of caffeine ....................................... 25

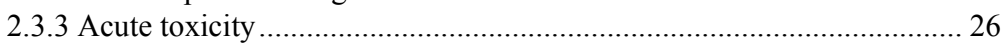

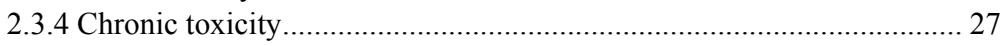

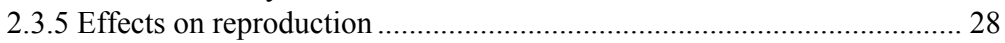

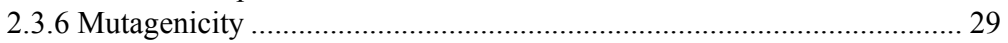

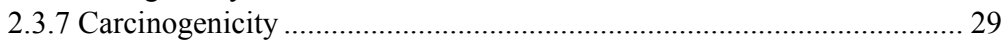

2.4 Effects on the central nervous system (CNS) …............................................ 30

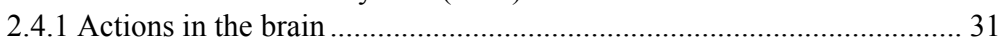

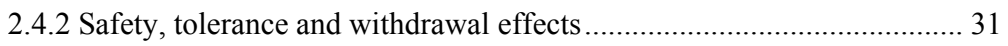

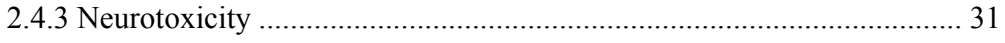

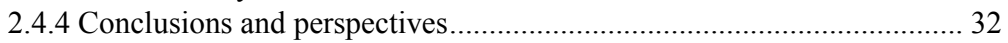

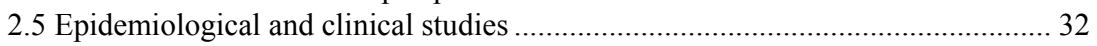

2.5.1 Tolerance, dependence and withdrawal symptoms ............................. 35

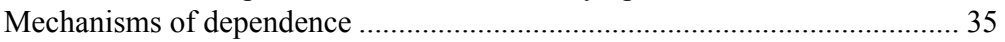

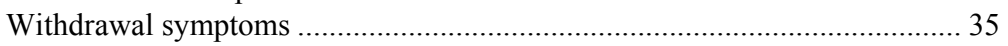

The withdrawal reversal hypothesis ............................................................. 36

Children/adolescents ........................................................................... 36

2.5.2 Cognitive performance and behaviour ............................................... 40

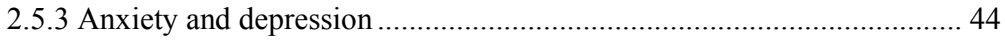

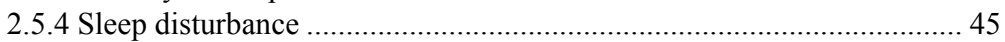

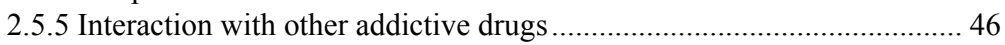

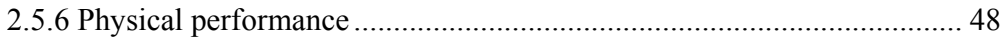

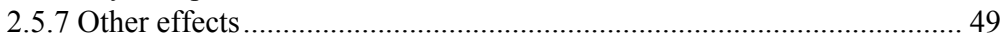

2.5.8 Summary, epidemiological studies...................................................... 49

2.5.9 Dose-response relationships and establishment of safe intakes............. 50

3. Intake of caffeine among children and adolescents in the Nordic countries .................. 57

Sources of information about consumption of caffeine-containing

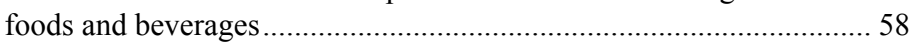

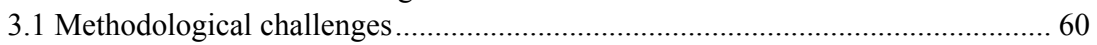

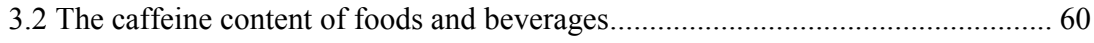

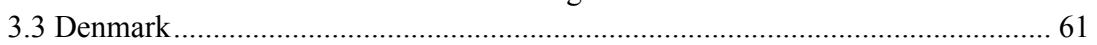

3.3.1 Trends in the consumption of caffeinated beverages................................ 61

3.3.2 Consumption of caffeine-containing foods and beverages

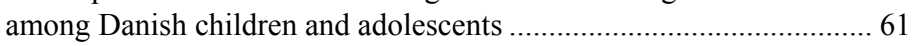

3.3.3 Exposure to caffeine among Danish children and adolescents ................ 65

3.3.4 Caffeine exposure per kg body weight in Danish children and adolescents. 


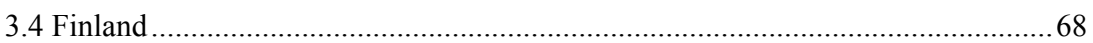

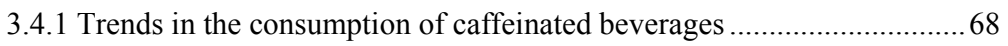

3.4.2 Consumption of caffeine-containing beverages among Finnish

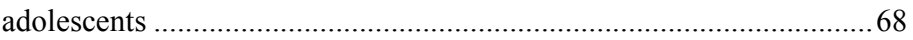

3.4.3 Exposure to caffeine among Finnish adolescents...................................... 70

3.4.4 Caffeine exposure per kg body weight in Finnish adolescents ............... 71

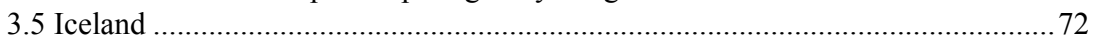

3.5.1 Trends in the consumption of caffeinated beverages ............................ 72

3.5.2 Consumption of caffeine-containing foods and beverages among Icelandic children and adolescents ...................................................... 72

3.5.3 Exposure to caffeine among Icelandic children and adolescents .............74

3.5.4 Caffeine exposure per $\mathrm{kg}$ body weight in Icelandic children and

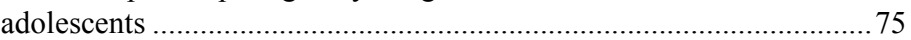

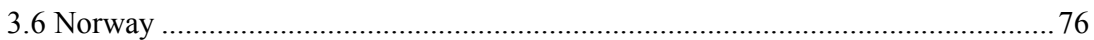

3.6.1 Trends in the consumption of caffeinated beverages ............................. 76

3.6.2 Consumption of caffeine-containing foods and beverages among Norwegian children and adolescents ................................................... 77

3.6.3 Exposure to caffeine among Norwegian children and adolescents ......... 79

3.6.4 Caffeine exposure per $\mathrm{kg}$ body weight in Norwegian children and

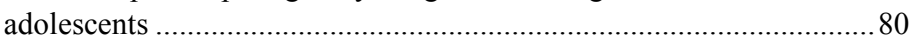

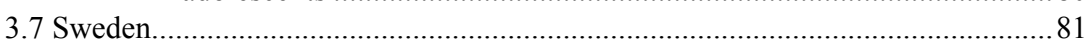

3.7.1 Trends in the consumption of caffeinated beverages .............................. 81

3.7.2 Consumption of caffeine-containing foods and beverages

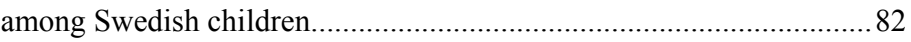

3.7.3 Exposure to caffeine among Swedish children ..................................... 84

3.7.4 Caffeine exposure per kg body weight in Swedish children .....................86

3.8 Summary of consumption data in the Nordic countries ...................................... 87

3.8.1 Overall trends, soft drink sales in the Nordic countries. ..........................87 87

3.8.2 Soft drink consumption among children and adolescents ....................... 88

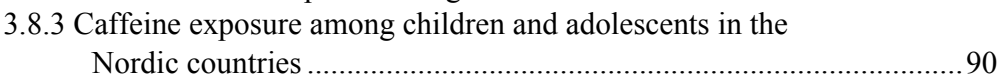

3.8.4 Caffeine exposure from cola drinks per kg body weight among children and adolescents in the Nordic countries...................................91

4. Risk characterisation of caffeine intake among children and adolescents .....................95

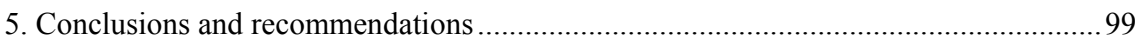

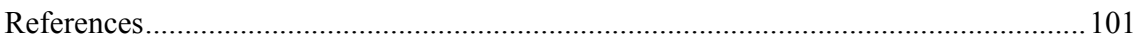

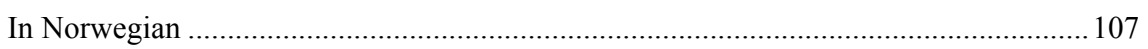

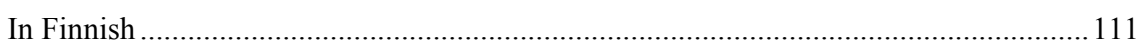

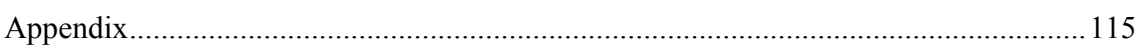

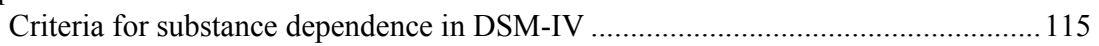




\section{Preface}

The present report was prepared by a Nordic Project Group under the Nordic Working Group on Food Toxicology and Risk Evaluation (NNT) within the Nordic Council of Ministers. The work was carried out in 2006 and 2007, and the report was accepted by NNT in January 2008.

The Nordic Project Group consisted of the following members:

Denmark

Henrik Rye Lam, National Food Institute, Technical University of Denmark Marta Axelstad Petersen, National Food Institute, Technical University of Denmark

Finland

Kirsi-Helena Liukkonen, Finnish Food Safety Authority (EVIRA)

Iceland

Elisabeth Jona Solbergsdottir, Department of Pharmacology and Toxicology, University of Iceland

Norway

Helle Margrete Meltzer (project leader), Norwegian Institute of Public Health Elisabeth Elind (secretary), Norwegian Institute of Public Health

Tor Øystein Fotland (project coordinator), Norwegian Scientific Committee for Food Safety (VKM)

Jan Alexander, Norwegian Institute of Public Health

Sweden

Helena Hallström, National Food Administration

The report was compiled and prepared by Elisabeth Elind, Tor Øystein Fotland and Helle Margrete Meltzer.

\section{Acknowledgements}

Hanne Boskov Hansen at the Danish Veterinary and Food Administration is thanked for her kind assistance concerning the Danish caffeine legislation. Tue Christensen and Sisse Fagt at the Department of Nutrition at the Technical University of Denmark are thanked for providing the caffeine consumption data from the Danish National Food Survey.

Special Turku Coronary Risk Factor Intervention Project for children (STRIP-study) at the University of Turku and Turku University Hospital are gratefully acknowledged for providing Finnish consumption data. The project leader of the STRIP-study is Professor Olli Simell. 
Holmfridur Thorgeirsdottir at the Public Health Institute of Iceland is thanked for her generous help providing consumption data from the dietary survey of The Icelandic Nutrition Council 2002. Zulema S. Porta and Brynhildur Briem at the Environment and Food Agency of Iceland are thanked for providing consumption data. Ragnheidur Osk Erlendsdottir from the Primary Health Care of the Capital Area in Iceland is thanked for providing mean body weight data.

Winnifried Jessie Larsen at the library of the Norwegian Institute of Public Health, Norway has been responsible for the main searches done. She is thanked for her generous help. Inger Therese Lillegaard at the University of Oslo was of great help providing Norwegian consumption data. Karin Melsom at the Norwegian Insitute of Public Helath has been invaluable with her help getting the manuscript moved to the format required by the Nordic Council of Ministers. Anne Finstad at the Norwegian Scientific Committee for Food Safety is thanked for her help with the Norwegian summary.

Harriet Green at the Division of Toxicology at the National Food Administration, Sweden, is thanked for kindly writing the chapter on Pharmacokinetics. Emma Ankarberg at the Division of Toxicology at the National Food Administration, Sweden is thanked for valuable comments about caffeine's effects on the central nervous system. Monika Pearson at the Department of Nutrition, National Food Administration, Sweden is thanked for providing consumption data from the national food survey on children in Sweden 2003. Christer Andersson at the Division of Toxicology at the National Food Administration, Sweden is thanked for kindly allowing us to use data and texts from the report Tema Nord: 2004:565 by Andersson H. C., Hallström H. and Kilhman B.A. 


\title{
Abbreviations and definitions
}

\author{
$A_{1}, A_{2} A, A_{2} B$ and $A_{3}$ receptors: $\quad$ Adenosine receptors \\ ADI: \\ Acceptable Daily Intake \\ Ad libitum: \\ at one's pleasure; to the full extent of one's wishes, as much as one \\ desires. In this text used to describe experiments where an animal \\ is provided free access to feed or water thereby allowing the animal \\ to self-regulate intake according to its biological needs \\ Ah-receptor: \\ Aryl hydrocarbon receptor \\ APA: \\ American Psychiatric Association \\ BBB: \\ blood-brain barrier \\ $\mathrm{BP}$ : \\ blood pressure \\ Bw: \\ body weight \\ CNS: \\ Central Nervous System \\ Codex Alimentarius: \\ The Codex Alimentarius is a collection of internationally recognized \\ standards, codes of practice, guidelines and other recommendations \\ relating to foods, food production and food safety under the aegis of \\ consumer protection. These texts are developed and maintained by \\ the Codex Alimentarius Commission. It lies under the Food and \\ Agriculture Organization of the United Nations (FAO), and the World \\ Health Organization (WHO). \\ Cola drinks/beverages: \\ Drinks containing caffeine from the Coca Cola or Pepsi Cola \\ companies \\ Cyclic AMP: \\ Cyclic adenosine monophosphate \\ CYP1A1: \\ Cytochrome P450 isoenzym \\ CYP1A2: \\ Cytochrome P450 isoenzym \\ CYP2D6: \\ CYP2E1: \\ CYP3A4: \\ DSM-IV/DSM-V: \\ EC: \\ EFSA: \\ Energy drinks: \\ Cytochrome P450 isoenzym \\ Cytochrome P450 isoenzym \\ Cytochrome P450 isoenzym \\ Diagnostic and Statistical Manual of Mental Disorders \\ European Communities \\ European Food Safety Authority \\ Soft drinks with a high caffeine content. May have added nutrients in \\ varying combinations, most often taurine and B-vitamines. Also \\ glukuronolactone might be added as well as substances like inositol. \\ EU: \\ European Union \\ FDA: \\ American Food and Drug Administration \\ FFQ: \\ food frequency questionnaire \\ GABA: \\ Gamma-aminobutyric acid \\ HR: \\ heart rate \\ IARC: \\ International Agency for Research on Cancer, an intergovernmental \\ agency forming part of WHO. \\ ICD: \\ International Classification of Diseases \\ In vitro: \\ Experiments in cell cultures and bacteria \\ JECFA: \\ Joint FAO/WHO Expert Committee on Food Additives \\ $\mathrm{Kg}$ : \\ Kilogram \\ the dissociation constant \\ LO(A)EL: \\ Lowest Observed (Adverse) Effect Level \\ Mean: \\ the average of a number of different amounts
}


Median:

NNT:

NO(A)EL:

$\mathrm{PAH}$ :

Per capita:

Percentile:

PCB:

RER:

SCF:

SD:

STRIP:

TDI:

UF:

WHO: the middle value of an ordered set of values. If the values are normally distributed, the median and mean value will be very close or the same

Nordic Group of Food Toxicology and Risk Assessment

No Observable (Adverse) Effect Level

Polycyclic Aromatic Hydrocarbons

the average per person for any given concern

the value of a variable below which a certain percent of observations fall

Polyclorinated Biphenyls

respiratory exchange ratio

Scientific Committee on Food, EU

Standard Deviation

Special Turku Coronary Risk Factor Intervention Project

Tolerable Daily Intake

Uncertainty factor

World Health Organization (United Nations) 


\title{
Summary
}

\author{
In English
}

In this report a risk assessment of caffeine in children and adolescents in the Nordic countries is presented. The report has special focus on effects on the central nervous system. It follows the standard template for risk assessments, starting with a hazard identification and characterisation of caffeine, followed by exposure and risk characterisation. An overview of consumption data on caffeine-containing foods, especially caffeinecontaining beverages consumed among children and adolescents in the Nordic countries, is presented in the exposure characterisation.

During the last couple of decades, consumption of caffeine-containing soft-drinks, especially cola drinks and so-called "energy-drinks", has increased substantially. Several fatal episodes, due to extreme intakes of stimulant drinks ("energy drinks") in combination with alcohol, have alerted regulatory bodies and the scientific community. International scientific institutions, such as the World Health Organisation (WHO), the Scientific Committee for Food (SCF) and the European Food Safety Authority (EFSA) have not determined an acceptable daily intake (ADI) or upper tolerable intake level for caffeine.

Regular daily consumption of caffeine-containing beverages is widespread in all age groups throughout the world, including children, who mainly are exposed through the consumption of cola drinks and cocoacontaining drinks and foods. Caffeine has multiple effects on the body, including effects on the cardiovascular system, increased renal excretion and gastric secretion. Possible adverse/unwanted effects of caffeine on children are most likely to appear in the central nervous system; accordingly, this topic is discussed rather thoroughly. The main molecular mechanism of action is its inhibitory effect on the adenosine receptors, which are found in many tissues including the brain. Although caffeine is one of the most extensively studied food constituents, most human studies have been performed in adults, and our knowledge about effects in children and adolescents is limited.

High exposure to caffeine in adults may induce health effects like nervousness, anxiety, restlessness, insomnia, tremors, and hyperesthesia. However, the doses of caffeine associated with severe frank neurotoxicity appear to be far above those commonly consumed. Evidence from many sources demonstrates that neural development extends from the embryonic period throughout adolescence, but available data are insufficient and do not allow a conclusion regarding eventual adverse effects of caffeine on this development. 
Studies on the effects of caffeine in children and adolescents have investigated tolerance, dependence and withdrawal symptoms, cognitive performance and behaviour, anxiety and depression. Although very relevant, no studies specially focusing on the effect of caffeine on sleep in children were found.

The following points summarise the epidemiological studies of relevance to children:

1. The epidemiological and clinical studies reveal that the scientific interest on the question of caffeine's effect on children and adolescents has been modest, especially during the last decade. Most studies were conducted long ago and did not always differentiate between the effects of caffeine and other dietary factors, such as sugar, and were in some cases performed with a small numbers of participants.

2. One overall impression is that individuals differ substantially in their susceptibility to caffeine-related adverse effects, and that this may influence their usage patterns of caffeine-containing foods and drinks.

3. A distinction should be made between adverse effects induced by caffeine abstinence in habitual caffeine consumers (withdrawal symptoms), and adverse effects induced in low- or non-consumers that are suddenly exposed to higher dosages.

4. As in adults, moderate intakes of caffeine have a stimulating effect on children and adolescents. Higher doses may produce negative effects like nervousness, jitteriness and anxiety, especially in those who normally are low-consumers.

5. Dependence and tolerance should be studied further.

6. Children/adolescents with any type of anxiety problem, with headaches, or with sleep problems, should be checked out for caffeine consumption.

Although there is a striking lack of quantitative data on the effect of caffeine in children and adolescents, the project group identified, through literature studies, several biological effects of low level caffeine exposure, such as tolerance development, withdrawal symptoms and anxiety and jitteriness. For tolerance development NOEL- and LOEL-values of 0.3 and $1.0-1.3 \mathrm{mg} / \mathrm{kg}$ bw respectively, were identified, whereas a LOAEL for anxiety and jitteriness was identified at an intake of 2.5 $\mathrm{mg} / \mathrm{kg}$ bw. Although it is known that caffeine can induce sleep disturbances in children, no studies in children with this endpoint were identified. It was noted that in non-habitual caffeine consuming adults, sleep disturbance was induced at a very low intake (in the same range as that inducing tolerance development). 
A large inter-individual variation both among children and adults in clearance rate of caffeine should be noted. In addition, the rate of biotransformation of caffeine is different between children and adults. Up to about one year of age the elimination is very slow, whereas up to about 10 to 12 years the clearance rate is increased in comparison with the rate in adults.

\section{Consumption of caffeine-containing foods and drinks among} children/adolescents in the Nordic countries

Caffeine-containing soft drinks are the main source of caffeine in children and adolescents. Based on dietary surveys among children aged 4-6 years in the Nordic countries, in consumers only, the caffeine exposure varies considerably, the $50^{\text {th }}$ percentile being about 0.3 to $0.5 \mathrm{mg} / \mathrm{kg}$ bw per day and the $95^{\text {th }}$ percentile about 1.0 to $1.7 \mathrm{mg} / \mathrm{kg}$ bw per day. Among teenagers, the Icelanders have the highest consumption of soft drinks among the Nordic countries. Their high overall consumption is reflected in the cola consumption among teenagers, being twice as high as in the other Nordic countries at the $50^{\text {th }}$ percentile and four times as high at the $95^{\text {th }}$ percentile. Ten percent of Icelandic 17-year-olds drink more than 1.5 litres of cola per day (equivalent to $200 \mathrm{mg}$ caffeine/day or $>3 \mathrm{mg}$ caffeine per kg bw per day), while the high-consumers among the teenagers in the other Nordic countries rarely exceed 0.5 litres per day (equivalent to $50 \mathrm{mg}$ caffeine or $1 \mathrm{mg}$ per $\mathrm{kg}$ bw per day). Among consumers only, the median intake was around 0.3 to $0.6 \mathrm{mg} / \mathrm{kg}$ bw per day in Denmark, Finland, Norway and Sweden, whereas it was around $1.3 \mathrm{mg} / \mathrm{kg}$ bw per day in Iceland. However, the age groups are not directly comparable. Furthermore, in neither of these intake estimates, caffeine from coffee, tea and chocolate were included. Thus, the true caffeine exposure is probably higher than stated above in all groups above the $50^{\text {th }}$ percentile, particularly among teenagers.

As far as our consumption data allow us to conclude, the exposure to caffeine among Nordic children 4-6 years is below the NOEL for tolerance development for approximately $50 \%$ of the children. Ten percent of the children with the highest consumption exceed the level where tolerance may develop.

Many Nordic teenagers have an intake of caffeine that can be associated with tolerance development and withdrawal symptoms, while approximately $20 \%$ of the teenagers might be exposed to levels of caffeine from caffeine-containing soft drinks inducing anxiety and jitteriness. There are large inter-individual differences in tolerance development and some reports indicate that a substantial fraction of teenagers might have a problem with controlling their caffeine intake.

In adults, there is a general acceptance for caffeine intake levels associated with tolerance development and withdrawal symptoms. This 
might, to a variable degree, also be the case among teenagers. However, such effects of caffeine are unwanted in children below the age of 12 . The Project Group therefore considers the current exposure of children in the Nordic countries to caffeine to be of concern. 


\section{Introduction}

Caffeine is a central nervous system and metabolic stimulant which has been enjoyed by humans for thousands of years through consumption of foods and beverages containing caffeine. Currently, regular daily consumption of caffeine-containing beverages is widespread throughout the world. Caffeine is provided through a number of different sources, most commonly though, through coffee, tea and soft drinks.

The last couple of decades, consumption of caffeine-containing softdrinks, especially cola drinks and so-called "energy-drinks", has increased substantially among children and adolescents and may be the main source of caffeine for those not drinking coffee or tea. Several fatal episodes, due to extreme intakes of stimulant drinks ("energy drinks") in combination with alcohol (Finnegan 2003), have alerted regulatory bodies and the scientific community. International scientific institutions, such as the World Health Organisation (WHO), the Scientific Committee for Food (SCF) and the European Food Safety Authority (EFSA) have not determined an ADI or upper tolerable intake level for caffeine. Although caffeine is one of the most extensively studied food constituents we have, most human studies have been performed in adults, and our knowledge about effects in children and adolescents is limited.

In Canada, a working group under the Food Directorate of Health Canada made a thorough review of the effects of caffeine on human health some years ago which also included children (Nawrot et al. 2003). Based on available evidence, they concluded with recommending children to consume less than $2.5 \mathrm{mg}$ caffeine per $\mathrm{kg}$ body weight per day. This is equivalent to approximately one cup of coffee or $6.6 \mathrm{dl}$ cola drink for a child weighing $35 \mathrm{~kg}$. Also in Denmark, the National Food Institute recommends that children and adolescents should not consume more than $2.5 \mathrm{mg}$ caffeine per kg body weight per day.

\section{Current legislation on caffeine in foodstuffs in the Nordic countries}

The European Communities (EC) legislation on caffeine in foodstuffs is not harmonised. However, in June 2002, a Commission Directive on the labelling of foodstuffs containing caffeine was adopted. According to Commission Directive 2002/67/EC, caffeine used as a flavour in the production or preparation of a foodstuff must be mentioned by name in the list of ingredients, immediately after the term "flavouring". Beverages which contain more than $150 \mathrm{mg} / \mathrm{l}$ caffeine, from whatever source, must be labelled with "high caffeine content". This message should be followed, in brackets, by the caffeine content expressed in $\mathrm{mg} / 100 \mathrm{ml}$. 
However, this requirement does not apply to beverages based on coffee, tea or coffee and tea extract where the name under which the product is sold includes the term "coffee" or "tea".

The national legislation on caffeine varies somewhat between the Nordic countries:

In Denmark it is generally not allowed to add caffeine to food. However, exceptions are made for soft drinks, which may contain up to 150 mg caffeine per litre, and for dietary supplements for which a daily dose of up to $300 \mathrm{mg}$ caffeine is accepted. The provisions in Directive 2002/67/EC about labelling of beverages with high caffeine content are therefore not relevant in Denmark, as it is not allowed to market products containing more than $150 \mathrm{mg} / 1$ except for beverages based on coffee or tea.

The Finnish Food Safety Authority Evira has issued guidelines on the labelling of caffeine containing energy drinks, candies, chewing gum, bars and food supplements. According to Evira, compulsory labelling does not sufficiently protect the most vulnerable groups and thus warnings on the labelling and instructions for use are considered necessary. All the above mentioned caffeine containing products have to bear the following warning statement: "Not for children, pregnant women or persons sensitive to caffeine". In addition, the highest daily dose must be given in exact amounts, with the exception of food supplements. For food supplements the content of caffeine in the whole package of the food supplement should not exceed $1200 \mathrm{mg}$. In Finland, there are no upper limits for addition of caffeine except that for food supplements packages.

From March 2005, Iceland has classified caffeine as a flavouring, and it is allowed to add to all beverages, which can contain caffeine in amounts up to $150 \mathrm{mg} / \mathrm{l}$.

Norway classifies caffeine as a pharmaceutical, and it is not allowed to add in foods, with an exception for beverages, which can contain caffeine or guarana in amounts up to $150 \mathrm{mg} / \mathrm{l}$.

In Sweden there are no upper limits for caffeine, neither in food supplements (see guidelines above) nor in other foods, but beverages must be labelled according to Directive 2002/67/EC if they contain more than 150 $\mathrm{mg} / \mathrm{l}$. In addition it may be noticed that, according to Regulation (EC) No 178/2002 of the European Parliament and of the Council, food shall not be placed on the market if it is injurious to health or unfit for human consumption.

In recent years the food industry has started to add caffeine to new products, such as beer, bread, candies, "energy bars", chewing gum and food supplements. The so-called "energy drinks" have been on the market for more than 10 years. Due to this an increasing amount of new caffeinecontaining food products, especially beverages, have been introduced to the market. 
Terms of reference

The aim of this report is to

1. give an overview of available toxicological information on the health effects of caffeine on children and adolescents

2. give an overview of consumption data on caffeine-containing foods, especially caffeine-containing beverages, among children and adolescents in the Nordic countries

3. perform a risk assessment of caffeine, based on possible negative health effects on children and adolescents

4. derive at a common Nordic recommendation for a safe intake level of caffeine in this population group, if possible

In this report, children and adolescents are defined as everyone between the ages of 4 and 18 years. The lower age limit is set because we have not found sufficient data on children below the age of 4, and the upper age level is set tentatively because most youngsters are fully developed physically by this age and are considered adult both legislatively and socially.

The report is organised as follows

In the chapter on hazard identification and characterization of caffeine (chapter 2.1 - 2.4), an outline is given of present-day knowledge of the pharmacology, kinetics and toxicity of caffeine. Special emphasis is put on the adverse effects of caffeine on the central nervous system, because much of the concern regarding caffeine exposure to children and adolescents is related to this field. As it is not an aim of the report to be comprehensive and detailed on mechanisms and molecular aspects, this information is rather brief, but based on in-depth reports (Andersson et al. 2005) and thorough scientific reviews (Fredholm et al. 1999) to provide a biological basis for understanding the effects of caffeine in children and adolescents.

In the chapter on evaluation of epidemiological and clinical studies (chapter 2.5), an extensive search for relevant publications was performed. The method used was electronic web searching using a series of search words. The databases, as well as the search words, are listed at the beginning of the chapter. Only studies published prior to August 2007 directly covering the topic of this report are included. A very limited number of studies on various health outcomes associated with caffeine intake among children/adolescents was found.

An important part of this report contains data concerning children and adolescent's consumption of caffeine-containing foods and beverages in the Nordic countries (chapter 3). These data were contributed by each country and are based on national dietary studies. The methods used vary between the different countries and give rise to some methodological 
concerns. However, overall we believe the data are good enough to be used in a risk assessment.

In the risk characterization chapter (chapter 4) we discuss what the probability is that children and adolescents will consume caffeine in amounts that have negative health effects, and eventually, what consequences this could lead to.

Subjects not discussed in the report

Studies done on caffeine and sports performance will be briefly mentioned (chapter 2.5.6) but not referred in depth here. Likewise, studies concerning caffeine metabolites as medicine for apnoea used on premature children and studies done on caffeine to medicate hyperactive children are not presented, for a review, see (Castellanos \& Rapoport 2002). Studies focusing on maternal intake of caffeine during pregnancy and the possible effects on foetal development, has recently been thoroughly discussed in the Nordic report TemaNord 2004:565 (Andersson et al. 2005), and the topic is therefore not included in this report. 


\section{Hazard identification and characterisation of caffeine}

\subsection{Chemical structure and sources}

Caffeine is a methyl-xanthine alkaloid with the systematic name 1,3,7-trimethyl-1H-purine-2,6(3H,7H)-dione and chemical name 1,3,7-trimethylxanthine (Figure 1). The highest concentrations are found in the leaves and beans of the coffee plant, in tea, yerba mate, guarana berries, the kola nut and cocoa. All together, caffeine is found in the beans, leaves, and fruit of more than 100 plants, where it is thought that it acts as a natural pesticide that paralyzes and kills certain insects feeding on the plants. Theophylline and theobromine are related compounds, characterized by only having two methyl groups each. When metabolized, methylxantines are de-methylated and excreted, the end product mainly being xanthine. The molecular weight of caffeine is 194.19 , the CAS number is $58-08-2$.<smiles>O=c1[nH]c(=O)c2[nH]cnc2[nH]1</smiles>

XANTHINE<smiles>Cn1c(=O)c2[nH]cnc2n(C)c1=O</smiles>

THEOPHYLLINE<smiles>Cn1c(=O)c2c(ncn2C)n(C)c1=O</smiles>

CAFFEINE<smiles>Cn1cnc2c1c(=O)[nH]c(=O)n2C</smiles>

THEOBROMINE

Figure 1. The structure of the most important xanthine molecules. 


\subsection{Pharmacokinetics of caffeine}

This chapter will summarize some general aspects of the pharmacokinetics of caffeine in man. Data from studies in experimental animals will only be reported to a limited degree. It should be noted that the majority of the studies on caffeine have been performed with pure compounds (e.g. caffeine in pill format), not in the natural form through foods containing methyl-xanthine.

In adult humans, caffeine is rapidly and essentially completely absorbed from the gastrointestinal tract and distributed into body tissues in approximate proportion to their water content with a volume distribution of about 0.6 litre $/ \mathrm{kg}$ bw (Gilman et al. 1996). Caffeine crosses the placenta, enters gonadal tissue and is secreted into milk. Caffeine also diffuses though the blood-brain barrier (A.C.S.H 1981; Gilbert 1976; Graham 1978; Kihlman 1977; Somani et al. 1980; Von Borstel 1983; Yesair et al. 1984).

The peak plasma level of caffeine is reached within 30 minutes after consumption of the pure compound. While plasma levels commonly found in consumers of caffeine-containing beverages are $0.2-2 \mu \mathrm{g} / \mathrm{ml}(1-10 \mu \mathrm{M})$ (Von Borstel 1983), the consumption of three cups of coffee results in a plasma level of around $10 \mu \mathrm{g} / \mathrm{ml}(52 \mu \mathrm{M})$ shortly after (Gilbert 1976). Weinstein and co-workers (1972) observed a peak plasma concentration of $30 \mu \mathrm{g} / \mathrm{ml}(155 \mu \mathrm{M})$ after four weeks following the administration of 800 $\mathrm{mg}$ caffeine per day in the form of tablets to 8 human volunteers (Weinstein et al. 1972). Although individuals vary greatly in their sensitivity to heavy doses of caffeine, toxic symptoms, such as severe restlessness and muscular tension and twitching, do not appear until concentrations rise higher than $30 \mu \mathrm{g} / \mathrm{ml}(155 \mu \mathrm{M})$ (Rall 1980).

Since most data on caffeine absorption, distribution, and metabolism have been produced after ingestion of pure compounds, Mumford et al (1996) compared caffeine absorption after oral administration of identical doses $(72 \mathrm{mg}$ ) of caffeine in capsules, cola beverages and chocolate candy. In comparison to capsules, caffeine absorption from cola and chocolate was delayed, and produced lower maximum caffeine plasma concentrations (around 75\%), which peaked at 1.5-2.0 hours after administration. The maximum caffeine plasma concentration was around 2 $\mu \mathrm{g} / \mathrm{ml}(10 \mu \mathrm{M})$ after consumption of capsules, $1.57 \mu \mathrm{g} / \mathrm{ml}(8 \mu \mathrm{M})$ after consumption of cola, and $1.50 \mu \mathrm{g} / \mathrm{ml}(7.7 \mu \mathrm{M})$ after consumption of chocolate candy (Mumford et al. 1996).

Although peak plasma levels of $10 \mu \mathrm{g} / \mathrm{ml}(50 \mu \mathrm{M})$ and above are not unusual following coffee consumption, the concentration of caffeine in plasma does not stay that high for very long. The half-life of caffeine in plasma for adult humans is normally about 3-6 hours (Figure 2), with females often having a shorter half-life than males. Plasma clearance rates are approximately 1 to $3 \mathrm{mg} / \mathrm{kg} /$ minute. One of the reasons for the 
rather wide variation in half-life of caffeine in humans is that different doses of caffeine have been studied and that the metabolism of caffeine is dose-dependent (Denaro et al. 1990; Kaplan et al. 1997; Trang et al. 1982).

Because of a dose-dependent metabolism of caffeine, regular caffeine consumption results in a steady state concentration of caffeine and metabolites in the body above that obtained with single doses. This may partly explain the inter- and intra-individual individual responses to caffeine-containing beverages and foodstuffs. Since it is known that caffeine affects gastric emptying and intestinal motility, it is possible that the peak level in plasma may shift over time when increasing the dose of caffeine. The half-life of caffeine in human plasma is, however, also dependent on a number of other factors, such as age, hormonal status, smoking habits, alcohol intake and the presence of other drugs.

In the foetus and newborn, which do not fully express the liver enzymes that metabolise caffeine, it has a much longer half-life. In the newborn it is close to 4 days (Aldridge et al. 1979; Aranda et al. 1979). By the age of 3-4 $1 / 2$ months, caffeine's half-life in plasma is down to about 14 hours, and is further reduced to $2-3$ hours by the age of 5-6 months (Aranda et al. 1979). Caffeine's half-life appears to remain between 2 and 3 hours at least through the ages of 6-13 years (Von Borstel, 1983). Thereafter it increases to 3 to 6 hours in adolescents and adults (Figure 2). These and other studies indicate that clearance of caffeine is 20 to $5 \%$ per kg body weight more rapid in children than in adults, which would have implications on the doses that would cause adverse effects in children in comparison with adults (Goodman \& Gilman's, 2006). The large inter-individual variation in clearance should be noted.

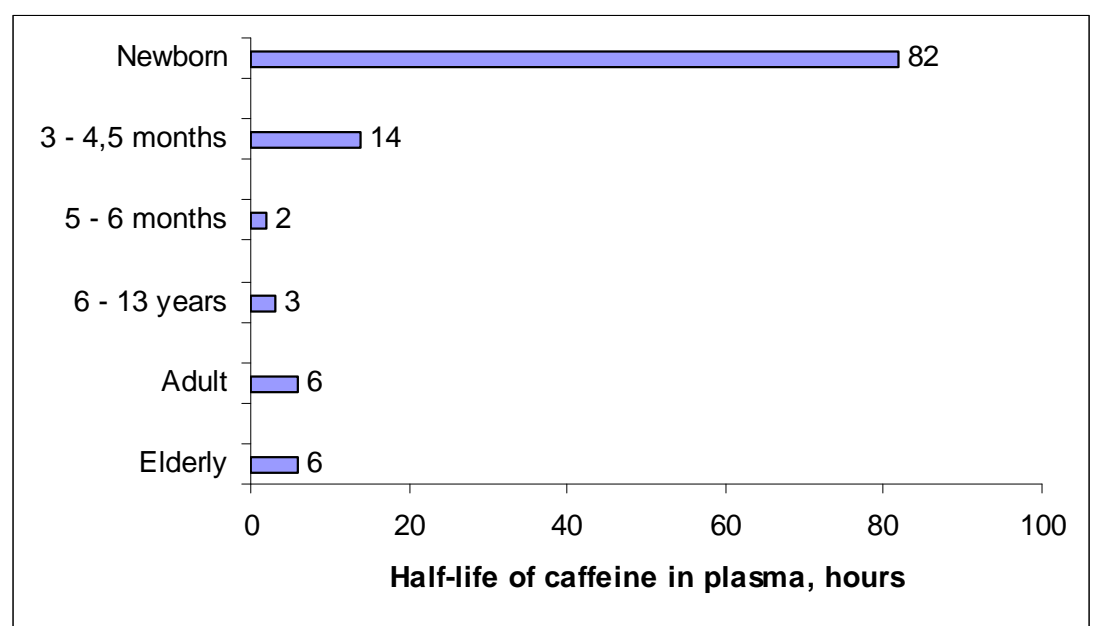

Figure 2. Average caffeine elimination (half-life) from plasma in humans as a function of age. Adapted from Von Borstel (Von Borstel 1983).

The metabolism of caffeine primarily occurs in the liver. In adults, less than $2 \%$ of the ingested caffeine is excreted unchanged in the urine. At 
least $98 \%$ of an oral dose is found metabolised in the urine and only 1$3 \%$ is excreted in the faeces. Infants up to the age of $8-9$ months have a greatly reduced ability to metabolize caffeine, excreting about $85 \%$ of the administered caffeine in the urine unchanged (Aldridge et al. 1979).

The four primary biotransformation products of caffeine in humans are paraxanthine (1,7-dimethylxanthine), theobromine (3,7-dimethylxanthine), theophylline (1,3-dimethylxanthine) and 1,3,7-dimethyluric acid (Figure 3). These metabolites are further degraded by demethylation, oxidation and ring opening (Arnaud 1984; Arnaud 1985; Kalow 1985). The most important first step in the biotransformation of caffeine in man is the removal of the 3-methyl group to yield 1,7-dimethylxanthine or paraxanthine. De-methylation of caffeine to paraxanthine usually represents almost $80 \%$ of the primary caffeine metabolism (Callahan et al. 1982; Callahan et al. 1983b), but different factors affecting this reaction may change the kinetics. In human urine, paraxanthine represents about $11 \%$ of the total metabolites of caffeine, 1,7-dimethylxanthine $14 \%$, 1methylxanthine 24\%, 5-acetyl-6-formylamino-3-methyluracil 10\%, and 1-methyluric acid 28\% (Branfman et al. 1983; Callahan et al. 1982; Callahan et al. 1983b; Cornish \& Christman 1957; Tang et al. 1983). The peak plasma concentrations of the caffeine metabolites occur hours after the peak level of caffeine is reached. For example, the highest level of theophylline is reached between 7.5 to 24 hours after ingestion of caffeine (Sved et al. 1976). 


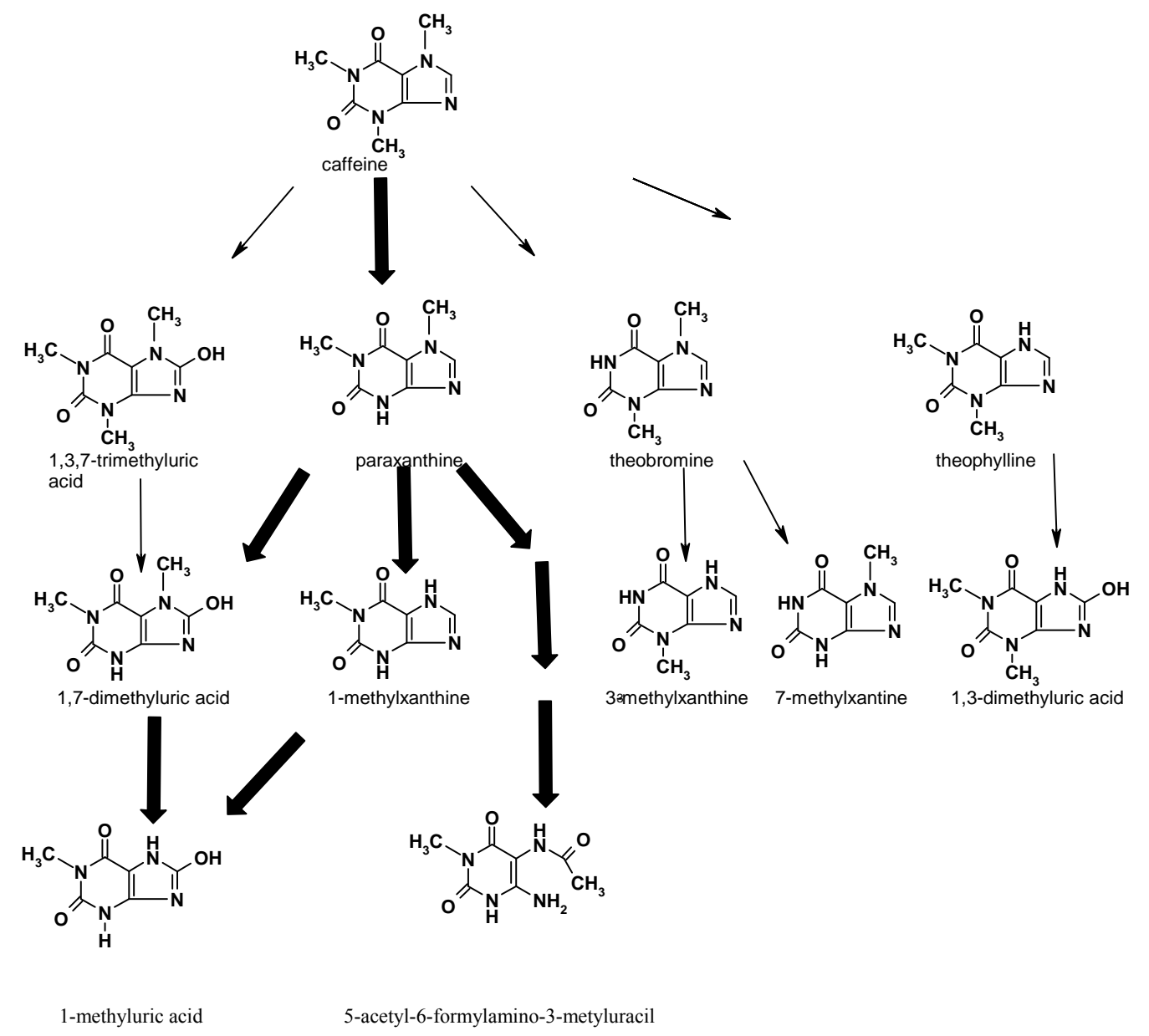

Figure 3. Caffeine metabolic pathways in the human body (Andersson et al. 2005).

Our knowledge about the enzymology of caffeine metabolism in man has increased during recent years (Berthou et al. 1988; Butler et al. 1989; Chung \& Cha 1997; Fuhr et al. 1992; Kalow 1985; Tassaneeyakul et al. 1994). CYP1A2 is the most essential enzyme in the metabolism (Ndemethylation and oxidation) of caffeine, although other CYP enzymes, flavin monooxygenase, and $\mathrm{N}$-acetyltransferase are also involved in its metabolism. CYP2E1, CYP3A4 and mutant CYP2D6 are three other CYP enzymes able to metabolise caffeine, but with lower affinity for the compound, and, therefore, may not have roles at physiologically relevant caffeine concentrations in humans. However, compared to CYP1A2, these enzymes are quantitatively less important (Berthou et al. 1991; Tassaneeyakul et al. 1994). The fifth enzyme in humans that can oxidise caffeine is CYP1A1. However, this enzyme is usually nearly absent in the liver, but may be induced by compounds acting via the Ah-receptor, for example compounds occurring in tobacco (Parkinson 1996).

Human beings are divided into poor and extensive acetylators of paraxanthine because of polymorphisms in $\mathrm{N}$-acetyl transferases. Caffeine is used as a probe to phenotype individuals with respect to acetylation ca- 
pacity and also CYP1A2 activity. Thus, it can be concluded that several enzymes are involved in the metabolism of caffeine, but quantitatively CYP1A2 is the key and most important enzyme in its metabolism and kinetics.

Both environmental and host factors may alter caffeine metabolism, e.g cigarette smoking, exposure to drugs such as oral contraceptives and diseases, in addition to pregnancy (Grant et al. 1983; Kalow 1985; Kinzig-Schippers et al. 1999; Nousbaum et al. 1994; Zevin \& Benowitz 1999). Partly due to the genetic traits in humans, also inter-individual variation of caffeine metabolism exists (Hardy et al. 1988; Kalow 1985).

\subsection{General toxicity of caffeine}

As a detailed discussion regarding the toxicological actions of caffeine is beyond the aim of this report, this chapter will only briefly review some general aspects of the pharmacological and toxicological actions of caffeine in man. Data from studies in experimental animals will only be discussed to a limited extent.

\subsubsection{Molecular mechanisms of caffeine action}

Adenosine receptors

Competitive antagonism for the adenosine receptors is currently believed to account for most of the pharmacological effects of caffeine, see chapter 2.4 (Chou \& Benowitz 1994; Fredholm 1995).

Adenosine is a naturally occurring molecule in cells and tissue fluids appearing in the nanomolar range under physiological conditions, but concentrations rise substantially during different forms of distress (Fredholm 2005). Adenosine interacts with four different adenosine receptors, called the $A_{1}, A_{2} A, A_{2} B$ and $A_{3}$ receptors. These receptors, which are Gprotein coupled trans-cell-membrane receptors, are widely distributed throughout the body tissues, and account for the multiplicity of the actions of adenosine. The different receptor subtypes are located to various organs (i.a. brain, GABAergic neurons, skeletal muscle, liver, kidney, adipose tissue, salvary glands, esophagus, colon, testis, lung, bronchi, pancreas, heart, blood vessels, immune system, bladder, adrenal gland and immune system) at different concentrations (Fredholm 2005, Magkos $\&$ Kavouras 2005). The physiological effects of adenosine activation of adenosine receptors are numerous. $\mathrm{A}_{1}$ and $\mathrm{A}_{2} \mathrm{~A}$ receptors are found in the brain, where adenosine functions also as a transmitter, and $\mathrm{A}_{2} \mathrm{~A}$ seems to be important for the regulation of heart activity and vascular system. While $A_{1}$ and $A_{2} A$ receptors are activated by basal physiological levels of adenosine, the $\mathrm{A}_{2} \mathrm{~B}$ receptor requires much higher (50-100 times) concentrations of adenosine to be activated, levels believed only to be pre- 
sent under extreme and pathological conditions (Fredholm 2005, Magkos \& Kavouras 2005). Upon activation, these receptors affect the cellular concentration of cyclic AMP via adenyl cyclase in the cell membrane.

Caffeine, being a xanthine, is a non-selective competitive antagonist of adenosine interaction with the $\mathrm{A}_{1}, \mathrm{~A}_{2} \mathrm{~A}$ and $\mathrm{A}_{2} \mathrm{~B}$ receptors, whereas it has no effect on $A_{3}$ receptors. The inhibitory potencies of caffeine for the different receptors given as $\mathrm{K}_{\mathrm{b}}$ (the dissociation constant) are 33.8, 12.3 and $15.5 \mu \mathrm{M}$ for the $\mathrm{A}_{1}, \mathrm{~A}_{2} \mathrm{~A}$ and $\mathrm{A}_{2} \mathrm{~B}$ receptors, respectively (Magkos \& Kavouras 2005). For paraxanthine, a major metabolite of caffeine, lower inhibitory concentrations have been reported.

It is noteworthy that caffeine is able to significantly block adenosine effects on $\mathrm{A}_{2} \mathrm{~A}$ (most potently) and $\mathrm{A}_{1}$ receptors already at the low concentrations (about $4 \mu \mathrm{M}$ ) achieved after a single cup of coffee see Figure 4 (Fredholm 1995), as a plasma concentration of $4-100 \mu \mathrm{M}$ caffeine is required to cause antagonism to the adenosine receptors. This plasma concentration corresponds to an intake of 50-1500 mg caffeine of adults, about $0.7-20 \mathrm{mg} / \mathrm{kg}$ bw This intake is equivalent to a consumption of approximately 1.2-12 litres of cola drinks or 1-10 cups of strong coffee (Andersson et al. 2005; Garrett \& Griffiths 1997; Sawynok \& Yaksh 1993). We have not found data on this topic involving children.

Other molecular targets

This mechanism of adenosine receptor antagonism is actually the only known that is relevant at the serum levels achieved by intake of caffeine via foods and beverages (Garrett \& Griffiths 1997). Other biological functions appear only to be affected at much higher concentrations of caffeine: to inhibit cyclic nucleotide breakdown via inhibition of phosphodiesterase, 20 times higher concentrations of caffeine are required; to block $\mathrm{GABA}_{\mathrm{A}}$ receptors, 40 times higher concentrations; and to mobilize intracellular calcium depots, concentrations of 100 times higher are needed. These latter levels are unlikely to be reached in humans by any form of normal use of caffeine-containing beverages (Fredholm et al. 1999).

\subsubsection{General pharmacological effects of caffeine}

The primary pharmacological effect of caffeine is stimulation of the central nervous system (Abbott 1986). Stimulation has commonly been described as increased arousal and vigilance, relief from fatigue and increase in sleep latency, improved performance (decreasing of psychomotor reaction time) and improved mood (Abbott 1986). There is an ongoing debate about the so called "withdrawal reversal hypothesis" which claims that the only benefits of caffeine on mood, alertness and mental performance are the reversal of withdrawal symptoms in habitual users (Rogers et al. 2005). However, the hypothesis is strongly refuted by oth- 
ers (Haskell et al. 2005). Further details on the effects of caffeine on the central nervous system are given in chapter 2.4.

Caffeine has prominent effects on the cardiovascular system, but as these effects are complex and sometimes even antagonistic, it may be difficult to predict the resulting effects (Hardman et al in (Gilman et al. 1996)). Generally, the following acute effects of caffeine on the cardiovascular system have been reported in individuals who have not developed tolerance: a modest increase in blood pressure (both systolic and diastolic), effects on heart rate (bradycardia or tachycardia depending on dose), and neuroendocrine effects like release of adrenalin, noradrenalin and renin (Gilman et al. 1996). On the respiratory system, the primary effect of caffeine is to increase the respiratory rate, probably by sensitising the medullary centre to carbon dioxide (Benowitz 1990).

Caffeine increases renal excretion of sodium and water. Increased diuresis is brought about by increased glomerular filtration rate and inhibited reabsorbtion of sodium and water. Caffeine increases sodium excretion by enhancing renin release from the kidney (Fredholm 1984). The effect is transient.

Caffeine has been shown to stimulate gastric secretion of hydrochloric acid and pepsin (Abbott 1986; Chou \& Benowitz 1994). These effects have, however, also been reported after intake of decaffeinated coffee, which indicates that also components in coffee other than caffeine may be of importance for the enhancement of gastric secretion (Abbott 1986).

Caffeine is known to influence free fatty acids, cortisol, metabolic rate and glucose (Benowitz 1990). In addition, an increased urinary excretion of calcium has been reported after caffeine exposure (Massey \& Opryszek 1990).

It is known that tolerance develops to some, but not to all pharmacological effects of caffeine. Tolerance develops at least to the cardiovascular effects of caffeine, while development of tolerance to the effects of caffeine in the central nervous system is equivocal although adaptive changes take place in the brain (Fredholm et al. 1999). There is evidence for a caffeine withdrawal syndrome including well known major abstinence symptoms like headache, increased fatigue but also many other symptoms (Juliano \& Griffiths 2004).

\subsubsection{Acute toxicity}

Adults

At higher doses caffeine may cause a number of different effects, including anxiety, tension, headache, insomnia, nervousness, loss of appetite, diarrhoea, dizziness, irritability, decrease in hand steadiness and analgesia. These symptoms can occur after either a long or short-term ingestion. This condition is generally known as "caffeinism" and can be observed at dose levels greater then $7-8 \mathrm{mg} / \mathrm{kg}$ bw/day or $500-600 \mathrm{mg} /$ day in adults 
(corresponding to approximately five cups of coffee) (Abbott 1986). Generally, the plasma concentration in connection with adverse effects has been reported to be $>30 \mu \mathrm{g} / \mathrm{ml}(150 \mu \mathrm{mol} / \mathrm{l})$ (Sawynok 1995).

In addition to the symptoms mentioned above, a variety of toxic effects of caffeine related to the cardiovascular system and gastrointestinal system may appear. Among the effects are hypotension, palpitations, tachycardia, arrythmias, flushing and marked circulatory failure, nausea, diarrhoea, epigastric pain and occasionally peptic ulcer and haematomesis (Abbott 1986). The effects can be reached at the same doses and plasma levels as described above.

The estimated lethal dose of caffeine in man is approximately 140 $170 \mathrm{mg} / \mathrm{kg}$ bw, equivalent to $8-10$ grams/day (corresponding to approximately $60-100$ cups of coffee (Abbott 1986; Sawynok 1995). In occasional case reports it has, however, been reported that fatalities in adults may have occurred at even lower dosage e.g. 5 grams/day, although there is also evidence of survival after a dosage of 30 grams (Moffat et al. 2004). Generally, toxic and fatal reactions have been associated with blood concentrations in excess of 15 and $80 \mathrm{mg} / 1$ respectively (Moffat et al. 2004). Fortunately, fatal poisoning associated with caffeine exposure is rare (Eteng et al. 1997; Sawynok 1995), although some cases of fatal poisoning after excessive doses of caffeine have recently been reported by (Holmgren et al. 2004; Kerrigan \& Lindsey 2005).

Children

Caffeine toxicity in children is manifested by severe emesis, tachycardia, central nervous system agitation and diuresis (Stavric 1988). In addition it has been reported in studies of children that high doses of caffeine (3-10 $\mathrm{mg} / \mathrm{kg} \mathrm{bw}$ ) produced increased ratings of headache, stomach-ache and also as previously mentioned nausea (Hughes \& Hale 1998). As in adults, fatal poisonings in children due to excessive caffeine intake seem to be rare, but a few case reports of severe acute intoxications in children with and without fatal outcome have been published (Moffat et al. 2004; Stavric 1988; Jorens et al. 1991). The lethal dose in children varies from case to case. As an example, it may be mentioned that for a 5-year-old girl a dosage of 3 grams caffeine was fatal (Dimaio \& Garriott 1974). Intoxications and even fatalities in a couple of adults and adolescents with a possible connection with consumption of alcohol and energy drinks containing caffeine (among other ingredients) have been reported, although there is no evidence of causality in these cases (Lehtihet et al. 2006).

\subsubsection{Chronic toxicity}

Since the primary aim of this report is to discuss pharmacological and adverse effects of caffeine in children and adolescents, the general 
chronic toxicity of caffeine is only briefly discussed. Further information on chronic toxicity can be obtained in the Nordic report on intake and adverse effects of methylxanthines in pregnancy (Andersson et al. 2005) and other reviews (Nawrot et al. 2003).

Adults

Some diseases, such as coronary heart disease, osteoporosis and different forms of cancer have been discussed in relation to caffeine exposure via foods and beverages. However, it is generally difficult to assess whether it is caffeine or other concomitant exposures that are responsible for development of reported adverse effects and/or eventually diseases. Common confounding factors in studies of this kind are smoking and/or alcohol consumption. Thus these factors also have to be carefully considered in the assessment of factors giving rise to chronic toxicity (Andersson et al. 2005).

In most prospective cohort studies, a significantly increased risk of cardiovascular disease in relation to coffee consumption has not been observed (Higdon \& Frei 2006). Regarding the risk of osteoporosis the impact of coffee or caffeine consumption is not clear in the light of the multifactorial etiology of the disease (Higdon \& Frei 2006).

\section{Children}

In comparison with the number of studies in adults, studies of the effects of long term caffeine exposure in children are scarce (Nawrot et al. 2003). Almost all studies of chronic effects of caffeine in children have focused on behavioural effects, please see chapter 2.5, in which this topic will be elaborated in detail.

\subsubsection{Effects on reproduction}

Based on results from studies on experimental animals showing teratogenic effects of caffeine in high doses, The American Food and Drug Administration (FDA) in 1980 issued recommendations to women to limit their intake of caffeine-containing beverages during pregnancy. Current available data from epidemiological studies, however, give no evidence that there is a relationship between high caffeine exposures and congenital malformations in humans. Two areas of concern have until now been identified regarding caffeine intake and pregnancy. In the first place it seems probable that at least relatively high intakes of caffeine may adversely affect the risk of having a spontaneous abortion, especially early in pregnancy. Secondly it is possible that a relationship between high intake of caffeine and reduced mean birth weight could exist. If such a reduction in birth weight exists it would probably be small and, thus, in most cases of minor importance clinically (Andersson et al. 2005). 
Recommendations about caffeine intake to pregnant women are thoroughly discussed in the TemaNord report of Andersson and co-workers (Andersson et al. 2005).

\subsubsection{Mutagenicity}

Mechanistic studies indicate that caffeine interacts in different ways with the DNA structure and DNA metabolism. The results from the few animal models that have been used indicate that caffeine only at doses 10fold higher than would be consumed by humans, and only in animals with dietary folate deficiency causes significant increases in spontaneous chromosomal alterations. However, these special experimental conditions make it difficult to extrapolate the animal data to humans (D'Ambrosio 1994). Using in vitro model systems, caffeine even at millimolar concentrations, does not appear to be genotoxic in many experimental systems. The dietary exposure of humans to caffeine results in much lower doses than those required to induce responses in short-term tests. The peak serum levels in humans are often in the micromolar range, which is 10- to 1000-fold lower than the levels used in animal and cell culture models. Thus, it seems unlikely that caffeine is genotoxic in humans at the doses generally reached by dietary intake of caffeine-containing beverages and foods (Andersson et al. 2005).

\subsubsection{Carcinogenicity}

In an evaluation of carcinogenic risks to humans, IARC (1991) noted that caffeine and coffee consumption is highly correlated in most of the published population studies. As this makes it very difficult to separate the two exposures in epidemiological studies it is in fact not possible to evaluate adequately the effect of caffeine per se. The conclusion of IARC (1991) is that there is inadequate evidence for carcinogenicity in humans and experimental animals of caffeine.

Most epidemiological studies in this field have actually studied the relationship between caffeine exposure measured as coffee/tea consumption and cancer development at different organ sites (Higdon \& Frei 2006). When assessing such studies it has to be borne in mind that caffeine containing beverages like coffee and tea are complex mixtures of many substances other than caffeine.

Regarding a relationship with coffee consumption there are some types of cancer that to a higher degree than other types have been suspected. These are breast cancer, cancer of the urinary bladder and prostate cancer. At present there seems to be little evidence for an association between consumption of coffee and breast cancer, while results of studies of bladder and prostate cancer are inconsistent (Nawrot et al. 2003). An inverse relation between consumption of coffee and incidence of colorec- 
tal cancer has been suggested, but as there is a discrepancy between results obtained in case control studies and cohort studies the overall conclusion remains open for discussion (Tavani \& La Vecchia 2004). No epidemiological studies regarding a relationship between consumption of foods containing caffeine in children and cancer development have been found.

\subsection{Effects on the central nervous system (CNS)}

Caffeine easily crosses the blood-brain barrier and is a potent CNS stimulant (Abbott 1986). The effects include an increase in spontaneous electrical activity, induction of convulsant activity, stimulation of locomotor activity, and increase of operant response rates, as seen in animal studies. Specifically, caffeine increases the release of the catecholamines norepinephrine and dopamine (Keijzers et al. 2002) and also interacts with the serotonergic system (Bach-Rojecky 2003). A short review of the psychopharmacological profile of caffeine is available (Andersson et al. 2005).

Several hypotheses have been presented as to mechanisms of action of caffeine on CNS. Here we will only give a brief outline of the most plausible hypothesis, which is related to caffeine's ability to reduce adenosine transmission in the brain (Fisone et al. 2004). For details, it is referred to Fredholm and co-worker's extensive review (Fredholm et al. 1999).

Adenosine $A_{1}$ and $A_{2 A}$ receptors, which are targets of caffeine action, are expressed in the basal ganglia (Fisone et al. 2004). Specifically, $A_{2 A}$ expression is highest in corpus striatum, nucleus accumbens and olfactory tubercles, although $\mathrm{A}_{2 \mathrm{~A}}$ receptors also occur in neurons and microglia in most other brain regions (Moreau \& Huber 1999). Adenosine receptor antagonism has also been implicated in the indirect action of caffeine on dopamine receptors (Garrett \& Griffiths 1997) due to the fact that adenosine and dopamine receptors exert opposing effects in the same postsynaptic nerve cells in the brain (Fredholm et al. 1999) i.e. caffeine induced adenosine receptor antagonism parallels or even induces the same action as does action of dopamine receptor activation. Affection of $\mathrm{A}_{2 \mathrm{~A}}$ receptors interferes with effects mediated by most of the principal neurotransmitters (glutamate and GABA) in corpus striatum including dopamine (Svenningsson et al. 1999). 


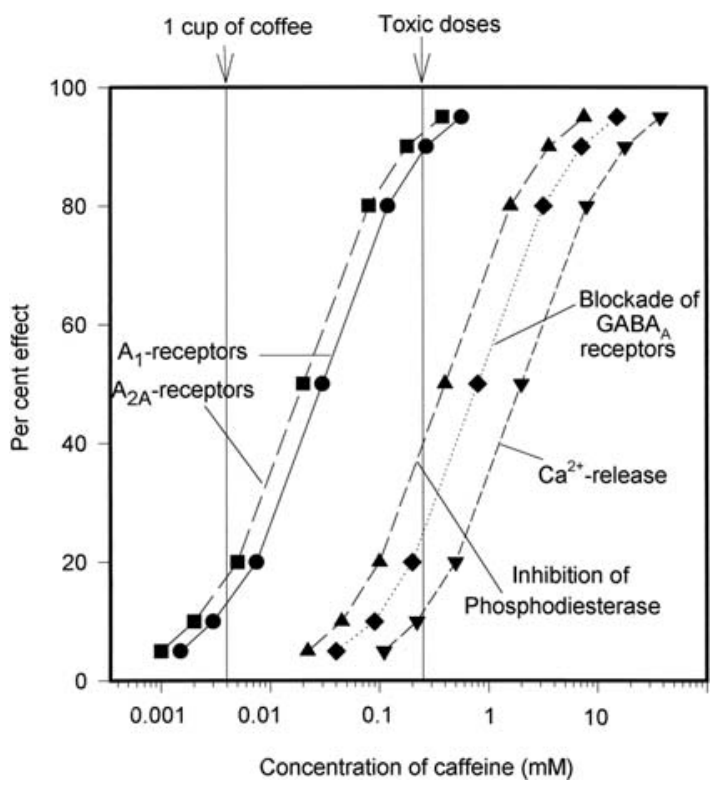

Figure 4. Effect of caffeine on different biochemical targets in relation to its levels in human adults, adapted from the TemaNord report of Andersson (Andersson et al. 2005) and (Fredholm 1995). The scale is given in $\mathrm{mM}$. To translate the levels to $\mu \mathrm{g} / \mathrm{ml}$, the numbers should be multiplied with the molecular weight of caffeine which is 194.19.

\subsubsection{Actions in the brain}

Relatively little is known about the signal transduction pathways that mediate the diverse biological functions attributed to the adenosine receptor subtypes. However, a number of membranal, cytosolic, and nuclear phosphoproteins regulated by phosphokinase activity were evaluated as potential mediators of adenosine $\mathrm{A}_{2 \mathrm{~A}}$ receptor signalling in the corpus striatum. Evidence indicates that these receptors modulate striatal dopaminergic neurotransmission and regulate motor control, vigilance, alertness, and arousal (Sahin et al. 2007).

\subsubsection{Safety, tolerance and withdrawal effects}

The human CNS does not seem to develop tolerance towards these stimulant effects of caffeine, although dependence and withdrawal symptoms have been reported (Andersson et al. 2005; Nehlig et al. 1992) including irritability, mood shifts, headache, drowsiness, or fatigue (Paluska 2003).

\subsubsection{Neurotoxicity}

Caffeine can cause seizures when administered to humans or animals in excessive doses (intravenous caffeine infusion at a rate of about 5, 12.5, and $25 \mathrm{mg} / \mathrm{kg}$ bw per minute). Studies on rats have shown development of functional tolerance to caffeine-induced seizures (Zhi \& Levy 1990). 
Acute exposure to caffeine can increase the risk of theophyllineinduced neurotoxicity (seizures) in rats (Yasuhara \& Levy 1988). Caffeine has been reported to increase neuronal oxygen consumption that may lead to neurotoxicity and cell death (Gepdiremen, et al. 1998) owing to oxidative stress induced apoptosis (Kang et al. 2002).

Intraperitoneal administration of caffeine at very high doses (50 $\mathrm{mg} / \mathrm{kg}$ bw, 3 times a day) produced neuronal death in various brain areas of neonatal rats. The pro-apoptotic protease caspase- 3 was activated to mediate apoptotic neuronal cell death (Kang et al. 2002).

The human nervous system is not fully developed in children and adolescents and, therefore, inherently during postnatal development is suspected to be more susceptible to toxic insult (Ladefoged et al. 1995). However, this aspect has received little attention and no adequate study has documented such effects of caffeine (Williams \& Ross 2007).

\subsubsection{Conclusions and perspectives}

High exposure to caffeine in adults may induce adverse health effects like nervousness, anxiety, restlessness, insomnia, tremors, and hyperesthesia. However, the doses of caffeine associated with severe neurotoxicity appear to be far above those commonly consumed. It is striking that there are very few data on the toxicity of caffeine in children. Accumulating evidence indicates that children are more vulnerable than adults when it comes to chemicals in general. Furthermore, environmental factors, including substances from the diet, can affect children differently from adults (WHO 2006). Of special relevance to this report are the potential hazards connected to the development of the nervous system. Evidence from numerous sources demonstrates that neural development extends from the embryonic period throughout adolescence (Slikker Jr \& Chang 1998; Williams \& Ross 2007), but available data are too insufficient to allow a conclusion regarding such adverse effects of caffeine. Consequently, focus should be placed on studies of the potential postnatal neurotoxicity of caffeine in the not fully developed human brain. Caffeine has been used for treatment of apnea in premature infants. In a recent study investigating neurodevelopmental effects of caffeine in prematurity, found that caffeine improved the rate of survival without neurodevelopmental disability at 18 to 21 months (Schmidt et al. 2007), indicating good tolerance. The latter study may illustrate how difficult it is to arrive at conclusions when it comes to the effects of caffeine on children.

\subsection{Epidemiological and clinical studies}

As mentioned in the introduction, there are only a limited number of epidemiological studies that have investigated caffeine intake in children and 
adolescents in relation to health outcomes. Their focus has mainly been on addiction and withdrawal symptoms, anxiety, depression and sleep disturbance. Accordingly, we have chosen to give each of these conditions their own sub-chapter. Very high intakes of caffeine and fatal intoxication are of special concern (Finnegan 2003; Lehtihet et al. 2006).

Each sub-chapter will start with a brief description of effects in adults, to put the descriptions of concern for children and adolescents into perspective.

Databases used: Pub Med/ Ovid MEDLINE ${ }^{\circledR}$, PsycINFO, AMED, CINAHL and EMBASE

Limits: English, Danish, Finnish, Icelandic, Norwegian and Swedish languages.

Search words: Caffeine, child*, health were the main search words. These were then combined with the following: methylxanthin*, caffeineintake/ingestion/consumption, health effects*, adverse effects*, negative effects*, anxiety /anxious, abstinence, cognitive performance, psychomotor performance, mood, dependence, addiction, hyperactivity, insomnia, depression, eating disorder* and blood pressure elevation.

Some of the published papers present results that are relevant to more than one topic (sub-chapter) and accordingly, they are described and referred to several times.

As a background to the description and discussion of tolerance, dependence and withdrawal symptoms, the diagnosis criteria for "dependence" set by the World Health Organization are presented. Furthermore, the USA definitions, called Diagnostic and Statistical Manual of Mental Disorders -IV or V (DSM-IV or DSM-V), are included as an appendix because they are often referred to in international publications (see appendix 1).

Definition of dependence

Criteria for substance dependence in ICD-10: three or more of the following must have been experienced or exhibited together at some time during the previous year:

1. a strong desire or sense of compulsion to take the substance:

2. difficulties in controlling substance-taking behaviour in terms of its onset, termination, or levels of use:

3. a physiological withdrawal state when substance use has ceased or been reduced, as evidenced by: the characteristic withdrawal syndrome for the substance; or use of the same (or a closely related) substance with the intention of relieving or avoiding withdrawal symptoms;

4. evidence of tolerance, such that increased doses of the psychoactive substance are required in order to achieve effects originally produced by lower doses; 
5. progressive neglect of alternative pleasures or interests because of psychoactive substance use, increased amount of time necessary to obtain or take the substance or to recover from its effects;

6. persisting with substance use despite clear evidence of overtly harmful consequences, such as harm to the liver through excessive drinking, depressive mood states consequent to heavy substance use, or drug-related impairment of cognitive functioning. Efforts should be made to determine that the user was actually, or could be expected to be, aware of the nature and extent of the harm.

Source: WHO, 1992 in Neuroscience of psychoactive substance use and dependence, World Health Organization, 2004

The WHO's criteria system and the American Psychiatric Association's system from 1987 and 1994 are very similar (Fredholm et al. 1999). In WHO's criteria list three or more of the above six criteria must be fulfilled for the diagnosis "dependence" to be set. In the US system, three or more of the seven criteria's listed must be fulfilled in order to use the diagnosis "dependence" (see appendix 1).

To be able to relate more easily to the dosages in the following text, we include here a small overview of the content of caffeine in the most common caffeine-containing beverages and some tentative values for the body burden per kg body weight in an adult and a child (Table 1). For details, please go to chapter 3 .

Table 1. The content of caffeine in commonly consumed caffeine-containing drinks

\begin{tabular}{|c|c|c|c|c|c|}
\hline & One unit (dl) & $\begin{array}{r}m g \text { caf- } \\
\text { feine/unit }\end{array}$ & mg caffeine/l & $\begin{array}{r}\text { mg caffeine } / \mathrm{kg} \text { bw } \\
\text { in } 70 \mathrm{~kg} \text { adult } \\
\text { consuming one } \\
\text { unit }\end{array}$ & $\begin{array}{r}\text { mg caffeine/kg bw } \\
\text { in a } 35 \mathrm{~kg} \text { child } \\
\text { consuming one } \\
\text { unit }\end{array}$ \\
\hline $\begin{array}{l}\text { Boilt and filter } \\
\text { coffee }\end{array}$ & 1.5 & $80-90$ & $500-600$ & 1.2 & 2.4 \\
\hline $\begin{array}{l}\text { Powder-coffee } \\
\text { (instant) }\end{array}$ & 1.5 & 60 & 400 & 0.86 & 1.7 \\
\hline Espresso & 0.35 & 40 & 1200 & 0.6 & 1.14 \\
\hline $\begin{array}{l}\text { Decaffeinated } \\
\text { coffee }\end{array}$ & 1.5 & 3 & 20 & 0.04 & 0.08 \\
\hline Tea & 2.0 & 50 & 260 & 0.7 & 1.4 \\
\hline Cola drinks & 5 & 66 & 130 & 0.94 & 1.9 \\
\hline $\begin{array}{l}\text { Energy drinks } \\
\text { (Battery, Magic) }\end{array}$ & 2.5 & $30-40$ & $120-175$ & 0,5 & 1 \\
\hline $\begin{array}{l}\text { Energy-drinks } \\
\text { (Red Bull) }\end{array}$ & 2.5 & 80 & 320 & 1,15 & 2,3 \\
\hline
\end{tabular}




\subsubsection{Tolerance, dependence and withdrawal symptoms}

Adults

Tolerance and dependence

A number of studies have investigated caffeine in relation to tolerance and dependence in adults, for recent reviews, see (Dews et al. 2002) or (Satel 2006). Here, a very brief summary is given.

Tolerance to some of the pharmacological effects of methylxanthines develops rapidly when caffeine is consumed on a regular basis (Hardman et al in (Gilman et al. 1996)). The blood-pressure increasing effects of caffeine shows virtually complete tolerance, the stimulant effects show partial tolerance, while the effects on sleep show little tolerance (Fredholm et al. 1999). The inter-individual variation in response is large. When three out of the six dependence criteria defined by WHO are fulfilled (see beginning of this chapter), a person consuming caffeine regularly can be characterized as dependent (Strain et al. 1994).

Caffeine has been shown to exhibit the features of a typical psychoactive substance of dependence according to the DSM-IV, see appendix (Strain et al. 1994). Strain concludes that it may be valuable to recognize caffeine dependence as a clinical syndrome, since some people feel compelled to continue caffeine use despite desires and recommendations to the contrary.

\section{Mechanisms of dependence}

The mechanisms by which caffeine may cause dependence are not fully understood. The theories given are mainly based on research done on animals (Fredholm et al. 1999). The theory discussed most often is connected to the finding that caffeine interacts with receptors that co-exist with dopamine receptors (see chapter 2.2). Dopamin is involved in the motivational symptoms of drug addiction (Self \& Nestler 1995 in (Fredholm et al. 1999)). Certain areas in the brain serve as centres for rewarding stimulus. Recent research suggests that the areas of nicotine addiction in the brain might have been found (Naqvi et al. 2007). Further research in this area might explore new and important information of areas in the brain involved in dependence of caffeine and other psychoactive drugs.

\section{Withdrawal symptoms}

A variety of withdrawal symptoms are described in adults. The most frequently reported is headache, which is characterised as being gradual in development, diffuse, throbbing, and sometimes severe. Other symptoms include drowsiness, depression, anxiety, fatigue, irritability and impaired ability to concentrate (Nehlig 1999; Strain et al. 1994). Withdrawal 
symptoms in adults generally begin about 12 to 20 hours after sudden cessation of caffeine consumption and reach a peak after 20 to 48 hours. However, in some individuals, the symptoms can appear after only 3 to 6 hours and can last for a week. Thus, even a short abstinence, equivalent to missing the morning cup of coffee, can lead to significant unpleasant effects (Fredholm et al. 1999).

\section{The withdrawal reversal hypothesis}

According to the withdrawal reversal hypothesis, the "beneficial" psychostimulant effects of caffeine are found only in the context of caffeine deprivation; that is, caffeine improves psychomotor and cognitive performance in habitual caffeine consumers following caffeine withdrawal. Furthermore, no net benefit is gained because performance is merely restored to "baseline" levels (Heatherley et al. 2005). The theory is widely debated, also by some of the dominant researches on health effects of caffeine on children, and is relevant to this report (Haskell et al. 2005; Heatherley et al. 2005).

\section{Children/adolescents}

Six studies have been found that are relevant to this chapter:

1. Caffeine Self-Administration and subjective effects in adolescents (Hale et al. 1995).

2. Caffeine dependence in schoolchildren? (Goldstein \& Wallace 1997).

3. Caffeine withdrawal in normal school-age children (Bernstein et al. 1998).

4. Caffeine dependence in teenagers (Bernstein et al. 2002).

5. Caffeine use and dependence in adolescents: one year follow up (Oberstar et al. 2002).

6. Psycho-stimulant and other effects of caffeine in 9- to 11-year-old children (Heatherley et al. 2006).

In the study by Hale and co-workers (Hale et al. 1995), 18 habitual highconsumers of cola drinks were included, i.e. participants had to consume a regular minimum amount of $360 \mathrm{ml}$ cola pr. day. On testing days, they consumed ad libitum amounts of cola or placebo, undergoing a diversity of tests every afternoon. Average intake of caffeine on testing days was $86( \pm 78) \mathrm{mg} /$ day, equivalent to $1.56 \mathrm{mg} / \mathrm{kg} \mathrm{bw} /$ day. Across-subject ratings of depression, drowsiness and fatigue were increased on noncaffeinated compared with caffeinated soft drink sampling days. The purpose of the study was mainly to investigate the reinforcement hypothesis. 
Goldstein \& Wallace studied 175 children 10-11 years old in an openlabel study. The children logged their usual caffeine consumption on one day and had no caffeine the next day (Goldstein \& Wallace 1997). The participants were considered low caffeine consumers if their caffeine intake was $10 \mathrm{mg} /$ day or less and high consumers if it was $50 \mathrm{mg} /$ day, equivalent to $1.3 \mathrm{mg} / \mathrm{kg}$ bw/day, or more. The high consumption group reported more stimulation on the day they ingested caffeine containing products as usual. They reported feeling wide-awake and fewer reported feeling sleepy. On the non-caffeine day significantly more high caffeine consumers than non consumers checked negative effects, such as having muscles aches, having trouble thinking clearly and feeling sleepy. Although the study had a pilot character, it clearly showed that children have the same stimulant effect of caffeine-containing beverages as adults, as well as similar withdrawal symptoms. Interestingly, muscle aches were more dominant than head aches on the withdrawal day.

Bernstein and co-workers studied 30 children, 8-12 years old, in a blinded repeated-measures intervention study (Bernstein et al. 1998). In this study only participants with a daily caffeine intake of at least $20 \mathrm{mg}$ per day fulfilled the criteria to participate. They were given 120-145 mg caffeine/day through soft drinks (Mountain Dew or Coca Cola) for two weeks (corresponding to 1.12 litre cola/day). Without knowing, they were then given caffeine-free drinks for 24 hours, before they again continued to drink their regular caffeine-containing drinks. The procedure was repeated several times. During caffeine-withdrawal, there was a significant deterioration in response time to a visual continuous performance test of attention. The finding was consistent with caffeine-withdrawal. The deterioration in response time appeared to persist for 1 week. The finding suggests that withdrawal from caffeine, after having been consumed in rather large amounts, may have detrimental effects on attention and performance in children of this age group.

In 2002, Bernstein and co-workers published a study where they had interviewed 35 adolescents (mean age 15 years) who consumed caffeine daily and had some features of caffeine dependence (Bernstein et al. 2002). Their mean caffeine consumption was $244 \mathrm{mg} /$ day $\pm 173 \mathrm{mg} /$ day based on beverage reporting from a three-day recording of dietary history, equivalent to $3.2 \pm 2.0 \mathrm{mg} / \mathrm{kg} /$ day. Of the 35 subjects, $42 \%$ reported tolerance to caffeine, $78 \%$ described withdrawal symptoms after cessation or reduction of caffeine intake and 39\% reported desire or unsuccessful attempts to control use, based on DSM-IV substance dependence criteria, see appendix 1 . There was no significant difference in the amount of caffeine consumed daily by caffeine dependent versus non-dependent teenagers. Six of the participants were marijuana-dependent, see chapter 2.5.5.

Twenty-one of the teenagers described in the above study were subject to a one-year follow-up (Oberstar et al. 2002). The mean caffeine con- 
sumption was $2.2 \mathrm{mg} / \mathrm{kg} / \mathrm{day}$. Five (24\%) met the criteria for caffeine dependence. The most commonly reported withdrawal symptoms in the dependent teenagers were feeling drowsy/tired, fatigued, or sluggish/slowed and headache. While $25 \%$ of the caffeine-dependent teenagers felt sad or depressed when caffeine was withdrawn, none of the nondependent participants did. Similarly, $42 \%$ of the dependent versus $9 \%$ of the nondependent participants felt bad when deprived of coffee. Caffeine dependence was not significantly related to mean daily caffeine intake. The study showed that caffeine dependence occurs in some adolescents who drink caffeine daily and is marked by similar symptoms to those found in adults.

In the study by Heatherley and co-workers, 26 children aged 9-11 years completed a double-blind, placebo-controlled study (Heatherley et al. 2006). Habitual caffeine consumers (mean daily caffeine intake $=109$ $\mathrm{mg}$ ) and non/low-consumers (mean daily caffeine intake $=12 \mathrm{mg}$ ) were tested on two separate days following overnight caffeine abstinence. On each day measures of cognitive performance (a number of search tasks), and self-rated mood and physical symptoms, including alertness and headache, were taken before and after administration of $50 \mathrm{mg}$ of caffeine, equivalent to $1.2 \mathrm{mg} / \mathrm{kg}$ body weight, or placebo. At baseline (before treatment), the habitual consumers showed poorer performance on the cognitive test than did the non/low-consumers, although no significant differences in mood or physical symptoms were found between the two groups. There were significant habit by treatment (caffeine vs. placebo) interactions for accuracy of performance and headache, and a significant main effect of treatment for alertness. Post hoc comparisons showed that caffeine administration improved the consumers' accuracy on the cognitive test (to near the level displayed by the non/low-consumers at baseline), but that it had no significant effect on the non/lowconsumers' performance. In the consumers, caffeine prevented an increase in headache that occurred after placebo, and it increased alertness relative to placebo. Again, however, caffeine did not significantly affect levels of headache or alertness in the non/low-consumers.

These results suggest that, like adults, children probably derive little or no benefit from habitual caffeine intake, although negative symptoms associated with overnight caffeine withdrawal are avoided or rapidly reversed by subsequent caffeine consumption. The authors suggest this to be regarded as a preliminary study due to the rather small number of participants, but still makes a point of how the results supports the "withdrawal reversal hypothesis".

\section{Discussion}

Caffeine has been shown to improve children's performance, however, this may be due to withdrawal reversal and not to a net improvement of performance (Heatherley et al. 2006). The hypothesis has not been tested 
in larger groups of children or adolescents and is widely debated (Haskell et al. 2005).

The more optimistic understanding of the effects of caffeine consumption following overnight caffeine abstinence is that although the first cup of coffee or tea only removes the negative effects of withdrawal, subsequent intake during the morning or later in the day may produce further improvement in mood and/or performance that represent a real benefit. This seems not to be the case because the dose-response relationship for caffeine and cognitive performance effects is very "flat" in the range above $30 \mathrm{mg}$ per day (Heatherley et al. 2006). At least 6 to 8 hours have been shown to be the interval before another dose of caffeine helps improve performance (James, 1997 in (Heatherley et al. 2006)). Children with moderate levels of habitual caffeine intake may not always be obtaining the caffeine that is necessary for them to function at the same level as those who rarely (or never) consume caffeine. The low consumers pattern of caffeine consumption seemed more varied compared with the high consumers. Low or non-consumers had a higher intake during the weekend, which may mean that they experience caffeine withdrawal on Mondays (Heatherley et al. 2006).

Short summary of tolerance, dependence and withdrawal symptoms

Studies on caffeine dependency and withdrawal symptoms in children and adolescents, although few, draw the same picture of the physical and psychological findings as in adults. Children and adolescents are stimulated by caffeine intake, and experience a number of withdrawal symptoms, including tiredness, when deprived of caffeine. Withdrawal symptoms vary between habitual high- and low-consumers, high-consumers feeling significantly more angry and unfocused when deprived of their intake. The effect can be induced at intake levels of $50 \mathrm{mg}$ caffeine, equivalent to half a cup of coffee or $1.2 \mathrm{mg} / \mathrm{kg}$ body weight. In $10-12$ year olds, muscle ache seems to be a more predominant withdrawal symptom than headache, while in teenagers, headache seems to be as common as in adults. Caffeine dependence does not seem to be significantly related to mean daily caffeine intake (Nehlig et al. 1992; Oberstar et al. 2002), but it is an open question if it is more related to frequency of consumption and/or duration of usage. It is also an open question if the apparent withdrawal syndrome represents a return to the individual's drug-free state (the withdrawal reversal hypothesis). A person who is intrinsically lacking in energy and is chronically sleepy may turn to a stimulant drug in the first place for its beneficial actions and become addicted to that drug (Goldstein \& Wallace 1997). 


\subsubsection{Cognitive performance and behaviour}

Adults

Caffeine affects psychomotor and cognitive performance, self-rated alertness and mood in adults (reviewed by e.g. (James 1998) Rogers \& Dernoncourt 1998). In a vast majority of these studies, caffeine was administered after a period of prior caffeine abstinence of between 10 and 24 hours, including overnight caffeine abstinence. They are thus of relevance to the discussion of the "withdrawal reversal hypothesis".

Taken together, the evidence in adults suggests that raising systemic caffeine concentration to a relatively low level in acutely caffeineabstinent participants has significant effects on performance, and possibly also mood, but that there is not an immediate further benefit at higher concentrations. Indeed, some results show adverse effects of high doses of caffeine, including increased anxiety, "jitteriness" and reduced hand steadiness (James 1998).

\section{Children/adolescents}

The following studies are relevant to this chapter:

1. Acute effects of caffeine in normal pre-pubertal boys (Elkins et al. 1981).

2. Behavioural and autonomic effects of caffeine in normal boys (Rapoport et al. 1981b).

3. Behavioural and cognitive effects of caffeine in boys and adult males (Rapoport et al. 1981a).

4. Behavioural effects of caffeine in children. Relationship between dietary choice and effects of caffeine challenge (Rapoport et al. 1984).

5. Caffeine effects on learning, performance, and anxiety in normal school-age children (Bernstein et al. 1994).

6. Psycho-stimulant and other effects of caffeine in 9- to 11-year-old children (Heatherley et al. 2006).

7. Two review articles: Behavioural effects of caffeine and other methylxanthines on children (Hughes \& Hale 1998). Effects of caffeine on development and behaviour in infancy and childhood: a review of the published literature (Castellanos \& Rapoport 2002).

A number of small studies of the behavioural effects of caffeine with paediatric populations were conducted in the 1970s (reviewed in (Elkins et al. 1981), but all were focused on hyperactive children and will therefore not be commented here.

The earliest study of caffeine and its effect on normal children was designed to compare the acute effect of a single dose of caffeine with the 
effect of amphetamine (Elkins et al. 1981). Nineteen boys 10.6 years ( \pm 2.5 ) were given $3 \mathrm{mg}$ caffeine $/ \mathrm{kg}$ bw, $10 \mathrm{mg}$ caffeine $/ \mathrm{kg}$ bw or placebo in a double-blind, crossover study design. Caffeine was shown to have somewhat the same effect as amphetamine as it also produced increased vigilance (watchfulness) and decreased reaction time. The highest doses were shown to increase motor activity, while total memory test (free recall) scores worsened on high doses of caffeine compared to placebo. It should be noted that the caffeine doses were rather high, equivalent to approximately 2 or 7 cups of coffee in an adult of $70 \mathrm{~kg}$.

Another group of nineteen boys $(9.8 \pm 1.8$ years $)$ were subject to a double-blind cross-over study on the behavioural, autonomic and side effects of caffeine (Rapoport et al. 1981b). The participants ingested either caffeine $(5 \mathrm{mg} / \mathrm{kg})$ or placebo twice a day for a 2-week period. Results were differentiated to be able to take into account those who initially were high- versus low-consumers of caffeine. Compliance was tested through saliva caffeine content. Caffeine increased autonomic reactivity in low consumers only. Behavioural and autonomic results were ambiguous for high users, indicating possible withdrawal symptoms.

In a third publication from 1981 (Rapoport et al. 1981a), the investigators used two different age group; nineteen pre-pubertal boys aged 10.6 years ( \pm 2.5 years) and 20 boys in the late adolescents / young adult men aged 21.7 years ( \pm 3.4 years). They were given a single dose of caffeine 3 $\mathrm{mg} / \mathrm{kg}$ bw, $10 \mathrm{mg} / \mathrm{kg}$ bw or placebo in a double-blind cross-over design, with 48 hours between each treatment period. They were all asked to follow a caffeine-free diet for 24 hours prior to study start and during the study.

The oldest study-group was divided into low-caffeine users and highcaffeine consumers, based on their daily caffeine intake. Low users were those consuming less than $300 \mathrm{mg}$ caffeine/day, and high users were those consuming more than $300 \mathrm{mg} / \mathrm{day}$. The mean intake of the twelve "low" consumers was $26 \mathrm{mg}( \pm 33 \mathrm{mg})$ a day. The "high" consumers had a daily intake of $565 \mathrm{mg}( \pm 160) \mathrm{mg}$. The low caffeine consumers did not show an increase in motor activity when given caffeine. The high caffeine consumers had a trend for more speech dysfluencies on placebo $(\mathrm{p}$ $<0.1$ ), while low caffeine consumers did not (Rapoport et al. 1981a). The high caffeine consumers experienced withdrawal symptoms when given placebo. They had a decreased pulse rate and decreased motor activity on placebo. They also showed a tendency to a lower reaction time, more omission (oversight/mistakes) errors and they had longer reaction (response) time (inter stimulus interval) on the continuous performance test while not given caffeine. The low consumers did not have any of these "placebo" or caffeine withdrawal symptoms.

The children tended to show more objective effects of caffeine than did the adult group, with increased motor activity, increased speech rate and decreased reaction time. Adults generally reported side effects fol- 
lowing caffeine intake while children did not, and side effects were more prominent for adults with a low habitual caffeine intake. Autonomic measures of arousal (stimulation) were similarly affected in both age groups.

In Rapoport (1984) nineteen high caffeine consumers (mean age 10.3 ) and nineteen matched low caffeine consumers were included from a total of 798 children interviewed with a 24-hour dietary recall (Rapoport et al. 1984). The total study period lasted for 7 weeks, including a 2 week baseline period eating their normal diet. This was followed by a two week caffeine free period. Then during week 4-7 of the study, the participants received either $5 \mathrm{mg} / \mathrm{kg}$ bw of caffeine twice a day or placebo for two weeks each, using a crossover design. It should be noted that these doses are substantial, equivalent to 3-4 cups of coffee daily in a $70 \mathrm{~kg}$ adult.

At baseline, consuming their regular diet, high consumers reported significantly greater anxiety symptoms and were significantly more likely to be described as "disobedient" by parents. The high consumers also had higher scores on the anxiety questionnaire, when not receiving caffeine but placebo $(p=0.02)$. The high consumers had by their teacher been perceived as more restless in the classroom than the low consumer group $(\mathrm{p}<0.01)$.

The low consumers reported in general greater negative side effects during caffeine consumption than did the high consumers. But some individual symptoms like the child being nervous and jittery" as rated by parents and presence of "stomach-ache" and "nausea" as rated by the child, increased equally for both high and low consumer groups on caffeine.

On caffeine, low consumers had significantly greater ratings of restless and fidgety behaviour and greater adverse effects (headache, stomach-ache, nausea, feeling faint, flushed, difficulty sleeping, and decreased appetite). High consumers' differed significantly from low consumers only in showing less restless and fidgety behaviour on caffeine. High consumers had no significant caffeine effects, except for "normalisation" of skin conductance response. There were no effects on vital signs and only a minor significant improvement on vigilance in the combined group. While not receiving caffeine, high consumers had higher scores on an anxiety questionnaire and tended to have lower autonomic arousal (less frequent spontaneous skin conductance response and lower skin conductance level). While receiving caffeine, low consumers were perceived by their parents as more emotional, inattentive, and restless, while high consumers were not rated as changed. These differences cannot be attributed to tolerance, withdrawal, or subject selection, and suggest a possible physiological basis in children for dietary caffeine preference.

In a study published in 1995 (Hale et al. 1995), eighteen adolescents (aged 11-15 years) underwent 6 independent, randomized, double-blind, placebo-controlled trials. In each trial, participants sampled a non- 
caffeinated and a caffeinated soft drink ( $33 \mathrm{mg}$ per $8 \mathrm{oz}$ ) in a 2 day crossover, followed by concurrent access to the same two soft drinks the following 2 days. Four of the eighteen (22\%) participants met a repeatability criterion, and one also met a statistical criterion for reliable caffeine selfadministration. Across-subjects ratings of depression, drowsiness, and fatigue were increased on non-caffeinated compared with caffeinated soft drink sampling days. These results are similar to, but less robust than, previous research in adults showing that $31-36 \%$ of coffee drinkers reliably self-administer caffeine and experience adverse effects from caffeine abstinence (Hale et al. 1995).

In the study by Bernstein and co-workers from 1994, 20 children completed a double-blind cross-over study of placebo and two doses of caffeine after an initial baseline test session (Bernstein et al. 1994). Caffeine produced dose-dependent improvements on a vigilance test (Test of Variables of Attention) and on a test of manual dexterity (Grooved Pegboard Test), but no change in two other cognitive tests. The side effects described in this study are presented in chapter 2.5.3.

A recently published study from UK included 26 children aged between 9 and 11 years who underwent a double-blinded, placebo controlled study (Heatherley et al. 2006). Habitual caffeine consumers (mean daily intake $=109 \mathrm{mg}$ ) and non/low-consumers (mean daily intake $=12$ $\mathrm{mg}$ ) were tested in two separate days following overnight caffeine abstinence. On each day, measures of cognitive performance and self-rated mood physical symptoms, including alertness and headache, were taken before and after administration of $50 \mathrm{mg}$ caffeine, equivalent to 1.2 $\mathrm{mg} / \mathrm{kg}$ body weight, or placebo. At baseline (before treatment) the habitual consumers showed poorer performance on the cognitive test than did the non/low-consumers, but there were no significant differences in mood and physical symptoms in the two groups. Caffeine administration improved the consumer's accuracy on the cognitive tests (to near the level displayed by the non/low-consumers at baseline), but it had no significant effect on the non/low-consumers performance. Among the habitual consumers, caffeine prevented an increase in headache that occurred after placebo, and it increased alertness relative to placebo.

\section{Short summary}

Studies on cognitive performance in children and adolescents have shown different results depending on the test persons being habitual versus nonhabitual users of caffeine. In most of the studies, caffeine improved cognitive performance in habitual users only. The doses used in almost all of these experiments were rather large: 3,5 or $10 \mathrm{mg}$ caffeine $/ \mathrm{kg}$ bw/day. In the only study published more recently, the habitual users did poorer on cognitive tests when withdrawn from caffeine (Heatherley et al. 2006). Caffeine re-introduction got them back up to their previous level before caffeine withdrawal. The non/low-consumers had little or no effect of caf- 
feine on performance. The authors noted that the results should be considered as preliminary because of relatively few participants, $n=26$. However, the study is consistent with the "withdrawal reversal hypothesis".

\subsubsection{Anxiety and depression}

Adults

Long-term overuse of caffeine can elicit a number of psychiatric disturbances in adults. Two such disorders recognized by the American Psychiatric Association (APA) are caffeine-induced sleep disorder and caffeineinduced anxiety disorder. In some individuals, large (ingestion of $500 \mathrm{mg}$ caffeine or more) amounts of caffeine can induce anxiety severe enough to necessitate clinical attention. This caffeine-induced anxiety disorder can take many forms, from generalised anxiety, to panic attacks, obsessive-compulsive symptoms, or even phobic symptoms. Because this condition can mimic organic mental disorders, such as panic disorder, generalised anxiety disorder, bipolar disorder, or even schizophrenia, a number of medical professionals believe caffeine-intoxicated people are routinely misdiagnosed and unnecessarily medicated when the treatment for caffeine-induced psychosis would simply be to withhold further caffeine. A study in the British Journal of Addiction concluded that caffeinism, although infrequently diagnosed, may afflict as many as one person in ten of the general population (Nehlig et al. 1992).

\section{Children}

The only studies covering the topic in children are:

1. Behavioural effects of caffeine in children (Rapoport et al. 1984).

2. Caffeine effects on learning, performance, and anxiety in normal school-age children (Bernstein et al. 1994).

The Rapoport study (Rapoport 1984) was presented in detail in the previous chapter (2.5.2). While not receiving caffeine, the high consumers had higher scores on an anxiety questionnaire and tended to have lower autonomic arousal. While receiving caffeine $(5 \mathrm{mg} / \mathrm{kg})$, low consumers were perceived as more emotional, inattentive and restless by their parents, while high consumers were not rated as changed.

In a double-blind, placebo-controlled crossover study from 1994 (Bernstein et al. 1994), twelve boys and nine girls (mean age $10.6 \pm 1.3$ ) were given either a low dose $(2.5 \mathrm{mg} / \mathrm{kg}$ body weight $)$ or a high dose of caffeine ( $5 \mathrm{mg} / \mathrm{kg}$ body weight). The purpose was to study the acute effects of caffeine on learning, performance, and anxiety in normal prepubertal children. The tests consisted of four testing periods with a whole week in between periods. The anxiety scale "Visual Analogue Scale for state anxiety", included expressions like: "how do I feel right now". Be- 
fore the testing period there was a baseline period during which dietary records, a child behaviour checklist was filled out. The subject average daily caffeine intake from beverages was calculated, but no differentiation of low and high habitual caffeine users were done. A modest and non-significant relationship was found between caffeine and self-reported anxiety, while there was a significant linear association between caffeine saliva level and the severity of state of anxiety. The result indicated that caffeine enhanced performance on a test of attention and on a motor task. Children also reported feeling less "sluggish" but somewhat more anxious. The caffeine dependent subjects in the study were significantly more anxious than non-dependent teenagers. This study forms the basis for the Canadian recommendations for children not to consume more than $2.5 \mathrm{mg}$ caffeine/kg bw/day (Nawrot et al. 2003).

Discussion and summary of anxiety and depression

Caffeine may induce altered behaviour in children and adolescents, including anxiety, although sensitivity to the effects varies widely. Unfortunately, the doses used in both studies described above were rather high, 2.5 or $5 \mathrm{mg}$ caffeine per kg body weight. Thus it is not possible to identify a lowest observed adverse effect level (LOAEL) close to the NOAEL based on these publications.

Caffeinism, including effects from carbonated caffeine-containing beverages, is listed among the physical conditions that may result in anxiety-like symptoms (Connolly \& Bernstein 2007). Caffeinism may therefore be diagnosed as anxiety. Anxiety disorders are said to represent one of the most common forms of psychopatology among children and adolescents, but they often go undetected and therefore untreated (Connolly \& Bernstein 2007).

\subsubsection{Sleep disturbance}

Adults

It is well known from studies in adults that caffeine may impair sleep onset. Bonnet and Arand found that doses of $400 \mathrm{mg}$ of caffeine taken three times a day (about $16 \mathrm{mg} / \mathrm{kg} /$ day) reduced the subjects' sleep efficiency to levels associated with insomnia (Bonnet \& Arand 1992). Doses of 300 to $400 \mathrm{mg}$ of caffeine prior to sleep onset resulted in 30 to $80 \mathrm{~min}$ utes reductions in total sleep time (Karacan et al. 1976; Nicholson \& Stone 1980). Smaller doses also have disruptive effects on sleep. A dose of $100 \mathrm{mg}$ (equivalent to one cup of strong coffee) resulted in a delay in sleep onset that was followed by poorer sleep quality for the next 3-4 hours (Nehlig et al. 1992). One study reported that the alerting effect of coffee lasted between 5.5 and 7.5 hours in two different experimental groups (Walsh et al. 1990), which is consistent with the 3 to 6 hours half- 
life of caffeine among adults. Habitual coffee drinkers seem to be relatively immune to the effects of caffeine on sleep (Nehlig et al. 1992).

\section{Children}

Only one relevant study on the subject of children and sleep disturbance has been found:

- Caffeine consumption and weekly sleep patterns in US seventh-, eighth-, and ninth-graders (Pollak \& Bright 2003).

The study by Pollack and Bright aimed at surveying caffeine consumption among adolescents and relate it to sleep characteristics. All the 191 participants from age 12-15 years kept a daily, 2-week diary of their sleep times and use of caffeine containing drinks and foods. The average caffeine intake was $62.7 \mathrm{mg} /$ day, range 0 to $800 \mathrm{mg} /$ day. Caffeine use peaked on Saturdays where the mean intake was $77.1 \mathrm{mg} / \mathrm{day}$. It fell to a minimum on weekdays with a mean of $54.0 \mathrm{mg}$ on Wednesday. In general, higher caffeine intake was associated with shorter nocturnal sleep duration $(\mathrm{p}=0.001)$, increased wake time after sleep onset $(\mathrm{p}=0.044)$, and increased daytime sleep $(p=0.006)$ (Pollak \& Bright 2003). The results of this study do not verify whether caffeine disturbed sleep or whether these adolescents may have consumed caffeine to counteract the residual effect of interrupted sleep on the following day. However, the latter is suggested by increased use of caffeine by those reporting more daytime naps.

\section{Short summary of sleep disturbance}

The one publication on effect of caffeine in children, described above, is insufficient to draw conclusions. On the other hand there are no published data indicating that caffeine would not have the same sleep-depriving effect in children and adolescents as in adults. In adults, doses less than $100 \mathrm{mg}$, equivalent to $1.4 \mathrm{mg} / \mathrm{kg} \mathrm{bw}$, do not seem to have effect (Dorfman \& Jarvik 1970).

\subsubsection{Interaction with other addictive drugs}

Adults

Simultaneous use of caffeine and substances such as tobacco and alcohol can produce an interactive effect. Cigarette smoking accelerates the metabolism of caffeine in smokers (Brown et al. 1988) and may explain why smokers tend to consume more coffee than non-smokers. Therefore, given the same initial sensitivity, the effects of caffeine are less pronounced in smokers than in non-smokers. 
Caffeine also interacts with alcohol, and coffee consumption is much higher in psychiatric patients who are alcoholics than in those who abstain from alcohol (Ayers et al. 1976).

Caffeine elimination is slower in women taking oral contraceptives (Callahan et al. 1983a).

Children

Relevant articles:

1. Relationship of alcohol, cigarette, and drug abuse in adulthood with alcohol, cigarette and coffee consumption in childhood (Tennant, Jr. \& Detels 1976).

2. Heavy caffeine use and the beginning of the substance use onset process (Collins et al. 1997).

3. Caffeine dependence in teenagers (Bernstein et al. 2002).

In 1976, Tennant published a retrospective study on 1354 US army soldiers, comparing their present use of nicotine, alcohol and drugs (like hashish and opiates) with early consumption of coffee, alcohol and cigarettes (Tennant, Jr. \& Detels 1976). Among the drug abusers, significantly more reported regular use of coffee, cigarettes and alcohol before the age of 12 than the non-abusers. We have not found similar studies to compare these results with.

One study with more than 5000 seventh graders completed a drug use survey. Eighty percent participated in a one-year follow-up survey (Collins et al. 1997). Those drinking less than, or equal to, 6 cups of coffee in the previous month were defined in the low risk category, while those that had been drinking more than 6 cups of coffee the last month were categorised in the high risk group. The caffeine users belonging to the low risk group were 1.5-2.5 times as likely to be free of tobacco and alcohol use in the seventh grade. In contrast, those seventh graders being in the high risk caffeine category were more likely to use tobacco or alcohol by the end of the one-year follow-up.

In Bernstein's interview study in high-caffeine-consuming adolescents, (see chapter 2.5.1), six out of the thirty-six participants were abusers of marijuana (Bernstein et al. 2002). They all reported significantly higher daily caffeine consumption than those without marijuana dependence $(372 \pm 203 \mathrm{mg}$ versus $217 \pm 164 \mathrm{mg} / \mathrm{day}(\mathrm{p}=0,044)$. The data also showed that subjects with nicotine dependence $(n=6)$ consumed more caffeine than those without nicotine dependence. Similar differences were not found when looking at relationships between alcohol intake and caffeine use. The mean intake of caffeine among these teenagers was much higher than reported in other studies in USA; they were especially selected based on their daily caffeine use. Bernstein raises the important question whether caffeine has the potential to be a gateway drug, and the 
extent to which early and regular use of caffeine may not only establish dependence, but may facilitate the acquisition of other drug-taking behaviour including use of nicotine, marijuana and alcohol.

Animal studies

Animal studies support the theory that caffeine may enhance the subjective effects of other drugs. Caffeine has in animal studies been shown to have a facilitating effect on the self-administration of cocaine and nicotine (Comer \& Carroll 1996; Horger et al. 1991; Schenk et al. 1994).

\subsubsection{Physical performance}

Adults

In adults, caffeine ingestion has been shown to extend time to fatigue, i.e. improve aerobic endurance, in situations where fatigue generally ensues within 30 to 60 minutes. To a lesser degree it also enhances short-term, high-intensity athletic performance (Magkos \& Kavouras 2005).

\section{Children}

Only one study has been found where caffeine's effect on physical performance in children has been studied:

- Effects of caffeine on physiological responses to exercise in young boys and girls (Turley \& Gerst 2006).

The purpose of the study was to describe the influence of caffeine on physiological responses to exercise in young children and determine whether sex differences in these responses exist. Twenty-six healthy 7- to 9-year-old boys and 26 healthy 7 - to 9-year-old girls volunteered to participate in a double-blind, randomized, double crossover study design. Each child randomly received both the placebo and caffeinated $(5 \mathrm{mg} / \mathrm{kg})$ drink twice, each on four separate days. Following a 1-hour wash-in period and resting measures, each child rode a cycle ergometer at 25 and then $50 \mathrm{~W}$ for $8 \mathrm{~min}$ each, while heart rate, blood pressure and oxygen consumption (VO2) were measured. Heart-rate was significantly $(p<$ 0.05 ) lower at rest and at 25 and $50 \mathrm{~W}$ in caffeine versus placebo in both boys and girls. Diastolic blood-pressure $(\mathrm{mm} \mathrm{Hg})$ was significantly (P $</=0.05$ ) higher at rest, at $25 \mathrm{~W}$ in both boys and girls, and at $50 \mathrm{~W}$ in boys, in caffeine versus placebo. Systolic blood-pressure ( $\mathrm{mm} \mathrm{Hg}$ ) was significantly $(\mathrm{P}</=0.05)$ higher at rest in both boys and girls, at $25 \mathrm{~W}$ in boys, and at $50 \mathrm{~W}$ in girls. During exercise, oxygen consumption was not different in caffeine versus placebo in either boys or girls. The authors concluded that a moderate dose of caffeine $(5 \mathrm{mg} / \mathrm{kg})$ does not affect metabolism in young children at low-moderate intensities of exercise. 
However, caffeine causes a significantly lower heart rate and higher blood pressure in both young boys and girls (Turley \& Gerst 2006).

\subsubsection{Other effects}

Headache

Only one study has been found investigating correlations between headache and caffeine consumption (Hering-Hanit \& Gadoth 2003). Thirty-six children and adolescents (mean age 9.2 years) with daily or near-daily headache (mean duration 1.8 years) combined with excessive intake in the form of cola drinks (minimum 1.5 1/day) were encouraged to reduce their cola consumption gradually over a 14-day period. There was a complete cessation of all headaches in 33 of the children. The intake of 1.5 $1 /$ day is equivalent to $20 \mathrm{mg}$ cafeine/day. If the children weighed $35 \mathrm{~kg}$, the amount is equivalent to $6.3 \mathrm{mg} / \mathrm{kg}$ bw/day.

The study indicates that children and adolescents with a high daily consumption of caffeine, in the form of cola drinks, may develop caffeine-induced headache. The authors encourage paediatricians and other health providers to take a detailed history of caffeine intake in youngsters with chronic, daily headache. If this is found excessive, the diagnosis of caffeine-induced headache should be considered.

\subsubsection{Summary, epidemiological studies}

The following points summarise the epidemiological studies of relevance to children:

1. This review of epidemiological and clinical studies reveals that the scientific interest on the question of caffeine's effect on children and adolescents has been modest, especially during the last decade. Most studies were conducted long ago and did not always differenttiate between the effects of caffeine and other dietary factors, such as sugar, and were in some cases performed with a small numbers of participants.

2. One overall impression is that individuals differ substantially in their susceptibility to caffeine-related adverse effects, and that this may influence their usage patterns of caffeine-containing foods and drinks.

3. A distinction should be made between adverse effects induced by caffeine abstinence in habitual caffeine consumers (withdrawal symptoms), and adverse effects induced in low- or non-consumers that are suddenly exposed to higher dosages.

4. As in adults, moderate intakes of caffeine has a stimulating effect on children and adolescents. Higher doses may produce negative effects like nervousness, jitteriness and anxiety, especially in those who normally are low-consumers. 
5. Dependence and tolerance should be studied further.

6. Children/adolescents with any type of anxiety problem, with headaches, or with sleep problems, should be checked out for caffeine consumption.

\subsubsection{Dose-response relationships and establishment of safe intakes.}

From the epidemiological and clinical studies described above we identified the following effects of caffeine in children and adolescents ${ }^{1}$ : development of tolerance, dependence and withdrawal symptoms, effects on cognitive performance and behaviour, induction of anxiety and depression, induction of sleep disturbance and induction of headache. Only few studies containing quantitative information on caffeine intakes and effects were identified. It should be noted that they have limitations in design as none were designed specifically to approach the question of establishing thresholds for different effects of caffeine in children. Ideally the studies should cover all age groups; however, only participants from 8 years up to 17 were included.

It is a matter of debate whether all the above described effects in children can be considered to be adverse effects. In most adults consuming coffee and other foods and drinks, tolerance development with withdrawal symptoms (headache, drowsiness, fatigue, irritability and impaired ability to concentrate) will occur, and is usually not considered to be an adverse effect. This might, to a variable degree, also be the case among teenagers. However, such effects of caffeine are unwanted in children below the age of 12. The Project Group therefore considers the current exposure of children in the Nordic countries to caffeine to be of concern.

On the other hand effects such as anxiety, sleep disturbances and headache should be viewed as adverse effects. In the following we have tried to extract relevant figures from the various published studies in order to estimate threshold values. Threshold parameters used in toxicological hazard characterisation for various effects are the "no observed adverse effect level" (NOAEL) and the "lowest observed adverse effect level" (LOAEL). For tolerance development, however, the Project Group decided to use the term NOEL and LOEL because the Project Group did not conclude whether or not this effect should be considered adverse.

In Tables 2-5 we have summarised the information from the relevant studies. In most of the studies, and in particular the early ones, the children have been exposed to rather high doses, in an experimental setting. However, in the more recent studies, information on habitual consumption of included participants and also lower challenge doses of caffeine were used, e.g. the most recent study, by Heatherley et al (Heatherley et

\footnotetext{
${ }^{1}$ In this context we consider the age groups up to 12 years as children and those between 13 and 18 years as adolescents.
} 
al. 2006) exposed children to a dose as low as $50 \mathrm{mg} /$ day to examine whether this low intake alleviated withdrawal symptoms. It should, however, be noted that due to the limited number of participants, the authors suggest that the results of this study should be regarded as preliminary. The studies in Tables 2-5 cover the age group from 8 up to 17 years of age with most of them covering ages from 8 to 13 years.

\section{NOEL, tolerance development with withdrawal symptoms}

The only study suited to establish a NOEL when studying the effects of caffeine on tolerance, dependence and withdrawal symptoms in children is the one by Goldstein \& Wallace (1997), where the low-consumer group ingested $10 \mathrm{mg}$ caffeine per day or less (Goldstein \& Wallace 1997). Participants were 175 children aged 11-12 years. The low- or non-consuming group (consuming less than $10 \mathrm{mg}$ caffeine/day), did not score for differences in various subjective reactions and symptoms (see chapter 2.5.1) between caffeine consumption and abstinence days compared to the group consuming higher levels of caffeine regularly. With an average weight of $38 \mathrm{~kg}$, this implies a NOEL of $0.3 \mathrm{mg} / \mathrm{kg}$ body weight/day. Results from this study must, however, be interpreted with caution as the design of the study was open labelled.

It is not possible to extract a NOEL from other studies with other outcomes.

\section{LOEL, tolerance development with withdrawal symptoms}

The study by Bernstein et al (Bernstein et al. 2002) on caffeine dependency in 36 teenagers 13 to 17 years of age, and its follow-up a year later by Oberstar et al (Oberstar et al. 2002), although only including high-consumers (consumption of minimum $50 \mathrm{mg} /$ day at inclusion), did identify caffeine dependence with withdrawal symptoms among the consumers. However, there was no significant difference in the daily amount of caffeine consumed by dependent versus nondependent adolescents. From this study it can be inferred that caffeine dependence can occur down to a consumption of $50 \mathrm{mg}$ per day. Assuming an average weight of $50 \mathrm{~kg}$, this indicates a LOEL of $1 \mathrm{mg} / \mathrm{kg}$ body weight/day for tolerance development.

The study on withdrawal symptoms by Heatherley and co-workers (Heatherley et al. 2006) included both low- and habitual high-consumers of caffeine-containing drinks, $\mathrm{n}=26$, age 9-11 years). Here, $50 \mathrm{mg}$ caffeine per day prevented the headache experienced on placebo in high-consumers. The average consumption among high consumers was $109 \mathrm{mg}$. Hence, a LOEL of $1.25 \mathrm{mg} / \mathrm{kg}$ body weight/day can be derived.

\section{LOAEL, anxiety}

In the study by Bernstein et al (1994) on 21 children with an average age of 10.6 years, the intervention doses were 2.5 and $5 \mathrm{mg} / \mathrm{kg} / \mathrm{bw}$ in addition to placebo. A dose-dependent relationship between caffeine concentrations in saliva and scores in one anxiety test was observed. Also the lowest intervention dose was associated with increase in anxiety scores. This study showed a LOAEL of $2.5 \mathrm{mg} / \mathrm{kg}$ bw. 
Headache

It was noted that headache was part of the withdrawal symptoms, however it was not possible to extract any quantitative information on dose and effect among caffeine consumers suffering from headache.

LOAEL, sleep disturbances

Sleep disturbance following caffeine intake is a commonly observed effect also in children. However, we have not identified studies related to sleep disturbance following caffeine intake in children. In non-habitual caffeine consuming adults, 1.4 $\mathrm{mg}$ caffeine/kg bw ingested shortly before bedtime delays sleep onset. As children show behavioural effects following caffeine intake at low doses, it is possible that they also might react in this way, but this remains to be studied. Because clearance of caffeine is more rapid in children than in adults, it is possible that this effect might occur at a higher intake (about $20-50 \%$ higher per $\mathrm{kg}$ bw) in children (Goodman \& Gilman's 2006).

Relationship between identified NOEL, LOELs and LOAELs, and plasma concentrations and adenosine receptors

The identified NOEL for tolerance development of $0.3 \mathrm{mg} / \mathrm{kg}$ bw would correspond to a plasma concentration of $2.5 \mu \mathrm{M}$ using a volume of distribution of 0.6 litre $/ \mathrm{kg}$ bw. The plasma concentration would probably be lower if the dose is divided up into several doses during the day. Plasma concentrations of $2.5 \mu \mathrm{M}$ or lower are according to $\mathrm{Kb}$ values given in chapters 2.3.1 and 2.4, Figure 4, too low for causing significant antagonism of the adenosine receptors. On the other hand the identified LOEL of tolerance development of $1-1.3 \mathrm{mg} / \mathrm{kg}$ body weight and a LOAEL for sleep disturbance derived from adults of $1.4 \mathrm{mg} / \mathrm{kg}$ bw (possibly 20 to $50 \%$ higher in children) would correspond to a plasma concentration of 8.4 to $11 \mu \mathrm{M}$ and $12 \mu \mathrm{M}$, respectively, which is sufficient to significantly block adenosine receptors $\mathrm{A} 1$ and $\mathrm{A} 22_{\mathrm{A}}$. An intake of $2.5 \mathrm{mg} / \mathrm{kg}$ bw/day, which induced anxiety, would in this model correspond to a plasma concentration of $21 \mu \mathrm{M}$ causing a more pronounced adenosine receptor inhibition.

Is it possible to derive a TDI for caffeine?

A tolerable intake is set to cover the whole life cycle. Caffeine is used as an accepted drug or stimulant in adults, but not necessarily in children and youngsters. In pregnant women restrictions on caffeine intake is recommended to avoid adverse effects on the foetus. Hence, setting a TDI, which should cover all life stages, does not seem appropriate, as recommendations for some life stages are in conflict with accepted use among male and non-pregnant female adults.

Extrapolation between age groups

Since the structure of receptor proteins is similar in children and adults, it is expected that the affinities of caffeine for adenosine receptors are inde- 
pendent of age. Hence it is likely that differences in clearance of caffeine from the body are a major determinant for differences in caffeine susceptibility between children and adults. The main enzyme responsible for caffeine clearance, CYP1A2, shows different activity with age (Lambert et al. 1986). The caffeine clearance is very low from birth up to approximately one year of age. Then it stays stable and high until puberty, when clearance decreases somewhat. In addition, there are large interindividual variations. The studies used in the derivation of threshold levels cover age group 8 to 12 , where caffeine clearance is expected to be at the highest level. Hence, the threshold levels derived should also cover all age groups between 1 and 12 years.

In summary, we have identified the following NOEL/LO(A)ELs:

Tolerance development: $\quad$ NOEL, $0.3 \mathrm{mg} / \mathrm{kg}$ bw

LOEL, $1.0-1.25 \mathrm{mg} / \mathrm{kg}$ bw

Anxiety:

LOAEL, $2.5 \mathrm{mg} / \mathrm{kg}$ bw

Sleep disturbance:

LOAEL $1.4 \mathrm{mg} / \mathrm{kg}$ bw (only values from adults, no value from children) 
Table 2. Relevant studies on tolerance development with withdrawal symptoms

\begin{tabular}{|c|c|c|c|c|c|c|c|}
\hline Study & Subjects & Design & Dose & Dose/kg bw/d & Suggested NOAEL/LOAEL & Outcome measure & Effect/comment \\
\hline $\begin{array}{l}\text { Hale et al. } \\
1995\end{array}$ & $\begin{array}{l}18 \text { adolescents } \\
\text { Age } 11-15 \text { years. }\end{array}$ & $\begin{array}{l}\text { Randomized, blinded } \\
\text { study. Only high- } \\
\text { consumers included. }\end{array}$ & $\begin{array}{l}\text { Caffeinated and non-caff. cola, } 33 \\
\mathrm{mg} \mathrm{pr} 240 \mathrm{ml} \text {. Ad lib consumption. } \\
\text { Average intake: } 86( \pm 78) \mathrm{mg} / \text { day. } \\
\text { Average weight: } 54.7 \mathrm{~kg} \text {. }\end{array}$ & $\begin{array}{l}\text { Average exposure on testing } \\
\text { days: } 1.56 \mathrm{mg} / \mathrm{kg} \text { bw/day }\end{array}$ & & $\begin{array}{l}\text { Behaviour, behaviour } \\
\text { tasks, Hand tremor test, } \\
\text { Conners Parent Rating } \\
\text { Scale. }\end{array}$ & $\begin{array}{l}\text { Increased ratings of drowsiness, } \\
\text { fatigue and depresssion on placebo } \\
\text { days, but findings were not consis- } \\
\text { tent. Only habitual high-consumers } \\
\text { included. }\end{array}$ \\
\hline $\begin{array}{l}\text { Goldstein \& } \\
\text { Wallace } \\
1997\end{array}$ & $\begin{array}{l}N=175 \\
\text { Age: } 11-12 \text { years. }\end{array}$ & $\begin{array}{l}\text { Kept log on caffeine } \\
\text { intake.Compared the } \\
\text { "low" consumer group } \\
\text { with "high" consumer } \\
\text { group in the log day } \\
\text { and the following } \\
\text { withdrawal day. }\end{array}$ & $\begin{array}{l}\text { Ad lib habitual consumption. Low- } \\
\text { consumers: } 10 \mathrm{mg} \text { or less daily. } \\
\text { High-consumer: } 50 \mathrm{mg} \text { or more } \\
\text { daily. Range: } 0-313 \mathrm{mg} \text {. } \\
\text { Average weight: } 38 \mathrm{~kg} \text {. }\end{array}$ & $\begin{array}{l}\text { Minimum exposure, high- } \\
\text { consumers: } 1.3 \mathrm{mg} / \mathrm{kg} \\
\text { bw/day }\end{array}$ & $\begin{array}{l}\text { NOEL: } 10 \mathrm{mg} / \mathrm{day}=0.3 \\
\mathrm{mg} / \mathrm{kg} \mathrm{bw} \quad \text { LOEL: } 1.3 \\
\mathrm{mg} / \mathrm{kg} \text { bw }\end{array}$ & $\begin{array}{l}\text { Profile of Moods Scale, } \\
\text { including positive (energy, } \\
\text { cheerfulness, friendliness } \\
\text { etc) and negative (tired, } \\
\text { angry etc) effects. }\end{array}$ & $\begin{array}{l}\text { High-consumers reported more } \\
\text { stimulation than did the low- } \\
\text { counsumers on test day and more } \\
\text { muscle aches on the withdrawal } \\
\text { day. }\end{array}$ \\
\hline $\begin{array}{l}\text { Bernstein et } \\
\text { al. } 1998\end{array}$ & $\begin{array}{l}30 \text { youngsters } \\
\text { Age: } 8-12 \text { years. } \\
\text { Average habitual } \\
\text { consumption of at } \\
\text { least } 20 \mathrm{mg} / \text { day. }\end{array}$ & $\begin{array}{l}\text { Single blind, within } \\
\text { subject, repeated } \\
\text { measures study. }\end{array}$ & $\begin{array}{l}120 \text { or } 146 \mathrm{mg} \text { caffiene/day for } 2 \\
\text { weeks (via Mountain Dew or Coca- } \\
\text { Cola). Then } 24 \text { hours with placebo } \\
\text { drink. Average weight } 37.9 \mathrm{~kg} \text {. }\end{array}$ & $\begin{array}{l}\text { Exposure dose: } 3 \text { - } 3.65 \\
\mathrm{mg} / \mathrm{kg} \text { bw/day }\end{array}$ & & $\begin{array}{l}\text { Test of Variables of } \\
\text { Attention. Caffeine Rating } \\
\text { Scale, several anxiety } \\
\text { scales. }\end{array}$ & $\begin{array}{l}\text { During caffeine withdrawal, there } \\
\text { was a significant deterioration in } \\
\text { response time to a visual continuous } \\
\text { performance test of attention. The } \\
\text { finding was consistent with caffeine- } \\
\text { withdrawal. The deterioration in } \\
\text { response time appeared to persist } \\
\text { for } 1 \text { week. }\end{array}$ \\
\hline $\begin{array}{l}\text { Bernstein et } \\
\text { al. } 2002\end{array}$ & $\begin{array}{l}N=36 \\
\text { Age: 13-17years. }\end{array}$ & $\begin{array}{l}\text { Outpatient evaluation of } \\
\text { highconsumers. }\end{array}$ & $\begin{array}{l}\text { Mean daily intake: } 244.4 \pm 173 \mathrm{mg} \\
\text { caffeine, range: } 50-767 \mathrm{mg} / \mathrm{day} \text {. }\end{array}$ & $\begin{array}{l}3.2 \pm 2.0 \mathrm{mg} \text { caffein } / \mathrm{kg} \\
\text { bw/day. }\end{array}$ & $\begin{array}{l}\text { LOEL: } 1 \mathrm{mg} / \mathrm{kg} \text { bw/day } \\
\text { (assuming bw = } 50 \mathrm{~kg} \text { ) }\end{array}$ & $\begin{array}{l}\text { Withdrawal symptoms. } \\
\text { Scoring on self report } \\
\text { measure of anxiety } \\
\text { (RCMAS) and depression } \\
\text { (BDI). }\end{array}$ & $\begin{array}{l}78 \% \text { described withdrawal symp- } \\
\text { toms and } 39 \% \text { reported problems } \\
\text { with controlling the use of caffeine. } \\
\text { Those that were caffeine dependent } \\
\text { were more anxious and depressed } \\
\text { than non dependent teenagers. }\end{array}$ \\
\hline $\begin{array}{l}\text { Oberstar et } \\
\text { al. } 2002\end{array}$ & $\begin{array}{l}N=21 \\
\text { Age: } 16.4 \pm 1.4 \\
\text { years. }\end{array}$ & $\begin{array}{l}\text { Follow-up study of } \\
\text { Bernstein et al. } 2002 .\end{array}$ & $180 \pm 152 \mathrm{mg} /$ day & $2.4 \pm 2.2 \mathrm{mg} / \mathrm{kg} \mathrm{bw}$ & $\begin{array}{l}\text { LOEL: } 1 \mathrm{mg} / \mathrm{kg} \text { bw/day } \\
\text { (assuming bw = } 50 \mathrm{~kg} \text { ) }\end{array}$ & $\begin{array}{l}\text { Diagnostic Interview } \\
\text { Schedule, Diet history, } \\
\text { alcohol and drug meas- } \\
\text { urement, depression } \\
\text { rating (BDI) and anxiety } \\
\text { rating (RCMAS). }\end{array}$ & $\begin{array}{l}\text { Withdrawal symptoms included } \\
\text { feeling drowsy/tired, fatigued, } \\
\text { sluggish, slowed down and } \\
\text { hadache. } 24 \% \text { were rated as } \\
\text { caffeine dependent. Dependency } \\
\text { could not be predicted by the } \\
\text { amount of caffeine intake. }\end{array}$ \\
\hline $\begin{array}{l}\text { Heatherley } \\
\text { et al. } 2006\end{array}$ & $\begin{array}{l}N=26 \\
\text { Age } 9-11 \text { years. }\end{array}$ & $\begin{array}{l}\text { Double blind placebo } \\
\text { controlled study. }\end{array}$ & $\begin{array}{l}\text { Highconsumers habitual intake: } \\
\text { mean: } 109 \text { mg/day. Low- } \\
\text { consumers: } 12 \mathrm{mg} / \text { day. Interven- } \\
\text { tion dose: } 50 \mathrm{mg} \text { caffeine or pla- } \\
\text { cebo. Average weight: } 39 \mathrm{~kg} \text {. }\end{array}$ & $\begin{array}{l}\text { Estimated exposure on } \\
\text { testing day: } 1.25 \mathrm{mg} / \mathrm{kg} \text { bw }\end{array}$ & LOEL: $1.25 \mathrm{mg} / \mathrm{kg}$ bw/day & $\begin{array}{l}\text { Cognitive tests, mood and } \\
\text { physical symptoms ques- } \\
\text { tionnaire. }\end{array}$ & $\begin{array}{l}\text { Caffeine improved accuracy in high-, } \\
\text { but not in low-consumers. Caffeine } \\
\text { prevented the headache that oc- } \\
\text { cured after placebo in high-, but not } \\
\text { low-consumers. }\end{array}$ \\
\hline
\end{tabular}


Table 3. Relevant studies on cognitive performance and behaviour

\begin{tabular}{|c|c|c|c|c|c|c|c|}
\hline Study & Subjects & Design & Dose & Dose/kg bw/d & $\begin{array}{l}\text { Suggested } \\
\text { NOAEL/LOAEL }\end{array}$ & Outcome measure & Effect/comment \\
\hline $\begin{array}{l}\text { Elkins et al. } \\
1981\end{array}$ & $\begin{array}{l}N=19 \text { boys } \\
\text { Age } 10.6 \pm 2.5 \\
\text { years. }\end{array}$ & $\begin{array}{l}\text { Double blind, placebo- } \\
\text { controlled study. }\end{array}$ & $\begin{array}{l}\text { Low dose: } 110 \pm 107 \mathrm{mg} \\
\text { High dose: } 369 \pm 107 \mathrm{mg}\end{array}$ & $\begin{array}{l}\text { Intervention: } 3 \mathrm{mg} \text { or } 10 \\
\mathrm{mg} / \mathrm{kg} \text { bw given in a } \\
\text { singel dose of Sprite } \\
\text { soda. }\end{array}$ & & $\begin{array}{l}\text { Mood, Children's Psychiatric Rating } \\
\text { Scale, motor activity, sensitivity to } \\
\text { light, reaction time, memory. }\end{array}$ & $\begin{array}{l}\text { Caffeine increased vigilance and } \\
\text { decreased reaction time }\end{array}$ \\
\hline $\begin{array}{l}\text { Rapoport et } \\
\text { al. 1981a }\end{array}$ & $\begin{array}{l}N=19 \text { boys } \\
\text { (Age } 10.6 \pm 2.5 \\
\text { years) and } \\
N=20 \text { college } \\
\text { men (Age } 21.7 \pm \\
3.4 \text { years). }\end{array}$ & $\begin{array}{l}\text { Double-blind placebo } \\
\text { controlled cross-over } \\
\text { design. Adults being } \\
\text { habitual high- and low- } \\
\text { consumers distin- } \\
\text { guished. }\end{array}$ & & $\begin{array}{l}\text { Intervention: } 3 \mathrm{mg} \text { or } 10 \\
\mathrm{mg} / \mathrm{kg} \text { bw given in a } \\
\text { singel dose of Sprite } \\
\text { soda. }\end{array}$ & & $\begin{array}{l}\text { Side effects \& behaviour ratings, } \\
\text { Activity, Speech, Memory, Reaction } \\
\text { time, Sustained attention measure, } \\
\text { Skin Conductanse. Salivary caffeine, } \\
\text { pulse and blood pressure was } \\
\text { checked } 1 \text { hour after ingestion. }\end{array}$ & $\begin{array}{l}\text { The children increased motor activity } \\
\text { and speech rate, and decreased } \\
\text { reaction time. They also had an } \\
\text { increase in feeling nervous and jittery. }\end{array}$ \\
\hline $\begin{array}{l}\text { Rapoport et } \\
\text { al. 1981b }\end{array}$ & $\begin{array}{l}N=19 \\
\text { Age } 9.8 \pm 1.8\end{array}$ & $\begin{array}{l}\text { Double blind placebo } \\
\text { controlled study over } 2 \\
\text { weeks. Habitual high- } \\
\text { and low-consumers } \\
\text { distinguished. }\end{array}$ & $\begin{array}{l}5 \mathrm{mg} / \mathrm{kg} \text { bw or placebo twice } \\
\text { pr day for } 2 \text { weeks }\end{array}$ & $10 \mathrm{mg} / \mathrm{kg}$ bw/day & & $\begin{array}{l}\text { Side effects (pain, heart poundering, } \\
\text { nervous/jittery etc), teachers rating } \\
\text { scale, performance tests, skin con- } \\
\text { ductance etc. }\end{array}$ & $\begin{array}{l}\text { Subjective side effects much more } \\
\text { pronounced in low-consumers than } \\
\text { high-counsumers. No difference } \\
\text { between groups found for blood } \\
\text { pressure, pulse or parents and teach- } \\
\text { ers ratings. }\end{array}$ \\
\hline $\begin{array}{l}\text { Rapoport et } \\
\text { al. } 1984\end{array}$ & $\begin{array}{l}\mathrm{N}=38 \\
\text { Age } 10 \pm 1.6 \\
\text { years. }\end{array}$ & $\begin{array}{l}\text { Double-blind, placebo } \\
\text { controlled study over } 7 \\
\text { weeks. Habitual high- } \\
\text { and low-consumers } \\
\text { distinguished. }\end{array}$ & $\begin{array}{l}5 \mathrm{mg} / \mathrm{kg} \text { bw or placebo twice } \\
\text { pr day for } 2 \text { weeks, crossover } \\
\text { design }\end{array}$ & $10 \mathrm{mg} / \mathrm{kg}$ bw/day & & $\begin{array}{l}\text { Behavioural tests, side effects, } \\
\text { continous performance tests, skin } \\
\text { conductance, salivary caffeine }\end{array}$ & $\begin{array}{l}\text { Higher scores on anxiety in high- } \\
\text { consumers when not receiving caf- } \\
\text { feine. When on caffeine, low- } \\
\text { cosumers were perceived by their } \\
\text { parents as more emotional, inattentive } \\
\text { and restless. No such ratings in high- } \\
\text { consumers. }\end{array}$ \\
\hline $\begin{array}{l}\text { Bernstein et } \\
\text { al. } 1994\end{array}$ & $\begin{array}{l}N=21 \\
(12 \text { boys \& } 9 \\
\text { girls) } \\
\text { Age: } 10.6 \pm 1.3 \\
\text { years. }\end{array}$ & $\begin{array}{l}\text { Double blind study } \\
\text { placebo-controlled } \\
\text { crossover study. } \\
\text { Caffeine administered } \\
\text { in cola bever- } \\
\text { ages. Testing } 30 \text { min- } \\
\text { utes after. }\end{array}$ & Placebo/ $2.5 \mathrm{mg} / 5 \mathrm{mg} / \mathrm{kg}$ bw & & & $\begin{array}{l}\text { Tests of attention, manual dexterity, } \\
\text { short-term menory, processing speed. } \\
\text { Anxiety: "how do I feel right now" just } \\
\text { after caff administration. }\end{array}$ & $\begin{array}{l}\text { Enhanced performance in two out of } \\
\text { four measures. Non significant trend } \\
\text { towards a higher level of anxiety } \\
(p=0.098) \text { and a significant linear } \\
\text { association between caffeine saliva } \\
\text { level and severity on this anxiety } \\
(p=0.034) \text {. }\end{array}$ \\
\hline $\begin{array}{l}\text { Heatherley } \\
\text { et al. } 2006\end{array}$ & $\begin{array}{l}N=26 \\
\text { Age } 9-11 \text { years. }\end{array}$ & $\begin{array}{l}\text { Double-blind, placebo } \\
\text { controlled cross-over } \\
\text { study. Habitual high- } \\
\text { and low-consumers } \\
\text { distinguished. }\end{array}$ & $\begin{array}{l}\text { Habitual hig-consumers: } 109 \\
\text { mg/day, habitual low- } \\
\text { consumers: } 12 \mathrm{mg} / \text { day. } \\
\text { Challenged with } 50 \mathrm{mg} \\
\text { caffeine or placebo in a soft } \\
\text { drink. }\end{array}$ & $\begin{array}{l}\text { Approx. } 1.25 \mathrm{mg} / \mathrm{kg} \mathrm{bw} \\
\text { per challenge }\end{array}$ & & $\begin{array}{l}\text { Cognitive performance, self-rated } \\
\text { mood and physical symptoms, } \\
\text { inlucing alertness and headache. }\end{array}$ & $\begin{array}{l}\text { Improved performance in high- } \\
\text { consumers, but not in low-consumers. } \\
\text { Caffeine prevented the headache on } \\
\text { placebo for high-consumers, but no } \\
\text { effect for low-consumers. }\end{array}$ \\
\hline
\end{tabular}


Table 4. Relevant studies on anxiety and depression

\begin{tabular}{|c|c|c|c|c|c|c|c|}
\hline Study & Subjects & Design & Dose & Dose/kg bw/d & Suggested NOAEL/LOAEL & Outcome measure & Effect/comment \\
\hline \multirow{2}{*}{$\begin{array}{l}\text { Rapoport } \\
\text { et al. } \\
1984\end{array}$} & $N=38$ & \multirow{2}{*}{$\begin{array}{l}\text { Double-blind, placebo controlled } \\
\text { study over } 7 \text { weeks. Habitual } \\
\text { high- and low-consumers } \\
\text { distinguished. }\end{array}$} & \multirow{2}{*}{$\begin{array}{l}5 \mathrm{mg} / \mathrm{kg} \text { bw or } \\
\text { placebo twice pr } \\
\text { day for } 2 \text { weeks, } \\
\text { crossover design }\end{array}$} & \multirow[t]{2}{*}{$10 \mathrm{mg} / \mathrm{kg}$ bw/day } & & \multirow{2}{*}{$\begin{array}{l}\text { Behavioural tests, side effects, } \\
\text { continous performance tests, } \\
\text { skin conductance, salivary } \\
\text { caffeine. }\end{array}$} & \multirow{2}{*}{$\begin{array}{l}\text { Higher scores on anxiety in high- } \\
\text { consumers when not receiving caffeine. } \\
\text { When on caffeine, low-cosumers were } \\
\text { perceived by their parents as more } \\
\text { emotional, inattentive and restless. No } \\
\text { such ratings in high-consumers. }\end{array}$} \\
\hline & $\begin{array}{l}\text { Age } 10 \pm 1.6 \\
\text { years. }\end{array}$ & & & & & & \\
\hline $\begin{array}{l}\text { Bernstein } \\
\text { et al. } \\
1994\end{array}$ & $\begin{array}{l}N=21 \\
(12 \text { boys \& } 9 \\
\text { girls) } \\
\text { Age: } 10.6 \pm 1.3 \\
\text { years. }\end{array}$ & $\begin{array}{l}\text { Double blind placebo-controlled } \\
\text { crossover study. Caffeine } \\
\text { administered in cola beverages. } \\
\text { Testing } 30 \text { minutes after. }\end{array}$ & $\begin{array}{l}\text { Placebo/ } 2,5 \mathrm{mg} / \\
5 \mathrm{mg} / \mathrm{kg} \mathrm{bw}\end{array}$ & $\begin{array}{l}\text { Placebo/ } 2,5 \mathrm{mg} / \\
5 \mathrm{mg} / \mathrm{kg} \mathrm{bw}\end{array}$ & $\begin{array}{l}\text { Based on studies in adults, } \\
\text { sensitive persons can develop } \\
\text { anxiety at very low doses. } \\
\text { Suggested LOAEL: } 2.5 \mathrm{mg} / \mathrm{kg} \\
\text { bw/day }\end{array}$ & $\begin{array}{l}\text { Tests of attention, manual } \\
\text { dexterity, short-term menory, } \\
\text { processing speed. Anxiety: "how } \\
\text { do I feel right now" after caffeine } \\
\text { administration. }\end{array}$ & $\begin{array}{l}\text { Enhanced performance in two out of four } \\
\text { measures. Non significant trend towards } \\
\text { a higher level of anxiety ( } p=0.098) \text { and a } \\
\text { significant linear association between } \\
\text { caffeine saliva level and severity on this } \\
\text { anxiety ( }(=0.034) \text {. }\end{array}$ \\
\hline
\end{tabular}

Table 5. Relevant studies on sleep disturbances

\begin{tabular}{|c|c|c|c|c|c|c|c|}
\hline Study & Subjects & Design & Dose & Dose/kg bw/d & Suggested NOAEL/LOAEL & Outcome measure & Effect/comment \\
\hline $\begin{array}{l}\text { Pollack et } \\
\text { al. } 2003\end{array}$ & $\begin{array}{l}\mathrm{N}=191 \\
\text { Age: } 12-15 \\
\text { years. }\end{array}$ & $\begin{array}{l}\text { Mean intake: } 62.7 \mathrm{mg} / \mathrm{day} \\
\text { ranged up to } 379.4 \mathrm{mg} / \text { day. } \\
\text { Range } 0 \text { - } 800 \mathrm{mg} / \mathrm{day} \text { (boys } \\
\text { consumed more - daily re- } \\
\text { cording for } 2 \text { weeks) }\end{array}$ & & $\begin{array}{l}\text { Estimated aver- } \\
\text { age exposure: } \\
1.5 \mathrm{mg} / \mathrm{kg} \text { bw/day }\end{array}$ & $\begin{array}{l}\text { In adults, } 1.4 \mathrm{mg} / \mathrm{kg} \text { bw ingested } \\
\text { shortly before bedtime delays } \\
\text { sleep onset. Suggested LOAEL: } \\
1.4 \mathrm{mg} / \mathrm{kg} \text { bw/day }\end{array}$ & $\begin{array}{l}\text { Consumption and sleep patterns } \\
\text { recorded each morning. }\end{array}$ & $\begin{array}{l}\text { Higher intake assosiated with shorter } \\
\text { nocturnal sleep duration and increased } \\
\text { wake time after sleep onset and in- } \\
\text { creased DAYTIME sleep. }\end{array}$ \\
\hline
\end{tabular}




\section{Intake of caffeine among children and adolescents in the Nordic countries}

This chapter presents an overview of the consumption of caffeinecontaining foods and beverages among children and adolescents in the Nordic countries. In order to estimate the dietary intake of caffeine, the caffeine concentration of the relevant foods and beverages must be known. The caffeine exposure is then estimated through multiplication of consumption with the concentrations of caffeine in the various foods and beverages. In toxicology and risk assessments, the usual way to estimate risk includes providing exposures of a substance per $\mathrm{kg}$ body weight. Accordingly, we have made tables where the total caffeine exposure in the various age-groups and exposure levels has been transformed to exposure per $\mathrm{kg}$. This enables us to compare Nordic exposure levels more directly with exposures provided in international literature. The final recommendations in this report will also be based on what seems to be a safe exposure level per kg body weight. When comparing exposure levels in the different Nordic countries, focus has been on soft drinks, since this is where we had the best data and futhermore, this is the main source of caffeine for youngsters.

In the past decade, large-scale, national dietary studies have generated relatively good knowledge about the dietary habits of the adult population in the Nordic countries. However, none of the Nordic countries has representative intake data on caffeine-containing foods and beverages that fully covers all the ambitions of this chapter, i.e. to describe caffeine intake accurately in all age groups of interest.

Denmark conducted a national food survey between 2000 and 2002, covering the ages 4 to 18 years, but did not differentiate between colaand non-cola beverages. Thus we have had to make assumptions as to caffeine exposure.

Finland does not have a national food survey being representative for children and adolescents. We have kindly been allowed to use data from the prospective STRIP study, comprising a rather selected group of participants, to be described later. Data on the 14- and 15-year-olds are from years 2004 to 2006 .

Iceland has three different sets of data; one survey on 6-year-old children, a second survey on 9- and 15-year-olds and a third survey on 17year-olds (15-19-year-olds). The consumption of cola beverages was 
specified in the surveys on 6- and 17-year-olds. The study on 17-yearolds was the only containing a detailed description of caffeine intake.

Norway has conducted a national food survey (Ungkost), covering 4-, 9- and 13-year-olds in 2000. However, also here there has been no differentiation between cola- and non-cola beverages, so some intake assumptions have had to be made.

$\underline{\text { Sweden }}$ has conducted several nationwide and representative surveys, including one on $4-$, 8- and 11-year-olds in 2003. In this survey, cola beverages were separated from other beverages, which made it possible to estimate caffeine intake very accurately in these age groups. However, there are no Swedish data on consumption among adolescents.

The focus of all the surveys has been on nutrient intake and certain ingredients, such as sugar. This might explain why questions making it possible to discern between caffeine-containing and non-caffeinecontaining beverages have not always been included. The methodological challenges this imposes on our intake estimations will be discussed alongside the presentation of the various data.

\section{Sources of information about consumption of caffeine-containing foods and beverages}

There are currently three levels of information about food consumption in the Nordic countries, i.e. from statistics on the national food supply, from national consumer surveys, and from dietary studies at an individual level.

Level 1 - Statistics on the food supply level

Statistics on the food supply provide information about the production, export, import and sale of food and show the amount of food available to the entire population.

The amount of food (per person) recorded in the statistics on the food supply will always be higher than comparable figures from other studies, such as consumer studies (level 2) or dietary studies, partly because the figures are expressed in total weight and because waste occurs in the food supply chain. As no such data are differentiated on age groups, we have chosen to include them only briefly at the beginning of each country's sub-chapter.

\section{Level 2 - Consumer studies}

Consumer studies are conducted by national statistical bureaus or commercial actors. These studies have different strengths and weaknesses. Consumer studies conducted by statistical bureaus show how much food is obtained (through purchase, self-catch, as gifts) in a nationally representative sample of private households during a 14-day period. Food eaten outside the home and the amount of food eaten by individual family 
members are not recorded. As also these data are unspecific, not being able to see the intake at an age-group level, they have been omitted in this report.

Level 3 - Dietary studies

During the last 100 years individual dietary studies have been used to survey the consumption of foodstuffs and estimate the intake of energy and nutrients. The methods used in these dietary studies are of two basic types: either retrospective or prospective. The retrospective studies are based on interviews about consumption during the past day (24-hour recall) or a longer period, usually the past year (dietary history) (Andersson et al. 2005). This may be followed by a more comprehensive self-administered dietary questionnaire (food frequency questionnaire (FFQ), which is also often used as the only method. The prospective methods often used, require the subjects to register all that has been consumed for a certain number of days; often 4 or 7 days. The registration can either be done by household measures (4- or 7-day food record) or by a weight scale (4- or 7-day weighed food record). Alternatively a duplicate of every portion of food and beverage consumed can be placed in a container stored properly for later chemical analysis (double portion technique).

In this chapter, most of the presented intake information comes from dietary studies at this level of information. Some studies are retrospective and some prospective, and will be described in more detail together with the presentation of the data.

Table 6 gives an overview over the different dietary methods used to estimate the caffeine intake in Nordic children and adolescents in this report.

Table 6 Overview of dietary methods used to estimate caffeine intake in children and adolescents in the Nordic countries

\begin{tabular}{|c|c|c|c|c|c|}
\hline & Denmark & Finland & Iceland & Norway & Sweden \\
\hline $\begin{array}{l}\text { Age } \\
\text { groups }\end{array}$ & $\begin{array}{l}\text { 4-18-year- } \\
\text { olds }\end{array}$ & $\begin{array}{l}\text { 14- and } \\
15 \text { - year-olds }\end{array}$ & $\begin{array}{l}6-, 9-, 15-\text { and } \\
17-\text { year-olds }\end{array}$ & $\begin{array}{l}\text { 4-, 9- and } \\
\text { 13-year-olds }\end{array}$ & $\begin{array}{l}\text { 4-, 8- and } \\
\text { 11-year-olds }\end{array}$ \\
\hline \multirow[t]{2}{*}{$\begin{array}{l}\text { Dietary } \\
\text { method }\end{array}$} & $\begin{array}{l}\text { 7-day food } \\
\text { diary }\end{array}$ & $\begin{array}{l}\text { 4-day food } \\
\text { diary }\end{array}$ & $\begin{array}{l}\text { 6-year-olds: } 3 \text { - } \\
\text { day food diary } \\
\text { All other age } \\
\text { groups: } 24 \text { hour } \\
\text { recall }\end{array}$ & $\begin{array}{l}\text { 4-day food } \\
\text { diary }\end{array}$ & $\begin{array}{l}\text { 4-day food } \\
\text { diary }\end{array}$ \\
\hline & & $\begin{array}{l}\text { Information on } \\
\text { cola drinks } \\
\text { specified }\end{array}$ & $\begin{array}{l}\text { Information on } \\
\text { cola drinks } \\
\text { specified for } \\
\text { the 6- and 17- } \\
\text { year-olds }\end{array}$ & & $\begin{array}{l}\text { Information on } \\
\text { cola drinks } \\
\text { specified }\end{array}$ \\
\hline
\end{tabular}




\subsection{Methodological challenges}

Presently, there is no dietary method available without error to measure food exposure. Therefore, evaluation of the dietary assessment tools should be performed, and results from these evaluation studies should be kept in mind in interpretation of results from the surveys.

Under-reporting of energy intake has been identified as a problem in numerous studies, both among adults and children. Moreover, studies among children have observed increasing under-reporting with age. Furthermore, under-reporting in dietary studies may not be food- or nutrientneutral. Several studies among adults have observed that fat intake, sweets and snacks are more likely than other foods to be under-reported (Goris et al. 2000; Krebs-Smith et al. 2000; Pryer et al. 1997). One of the few studies addressing this issue among children was conducted among the Norwegian 9-year-olds we present data from in this report (Lillegaard et al. 2007). Fifty-seven percent of the participants were classified as acceptable reporters, $39 \%$ as under-reporters and $4 \%$ as over-reporters when using the pre-coded food diary. Girls did not underestimate energy intake to the same extent as boys, with $14 \%$ and $23 \%$ underestimation respectively. However, under-reporting and acceptable reporting did not show systematic misreporting related to macronutrients, unhealthy foods or body mass index.

Intake assumptions

For soft drinks, when the food recording did not specify the type of beverage, assumptions have been made. If the study did not specify whether the intake of carbonated beverage was containing caffeine or not, we have partly made the assumption "if all drinks were cola drinks". In addition, exposure estimations have been made based on the assumption that $60 \%$ of the total intake of soft drinks is cola drinks. This percentage is derived from data from the Danish Brewers Association.

\subsection{The caffeine content of foods and beverages}

The brewery industry has provided information on the content of caffeine in cola soft drinks and "energy drinks" used in this report. Iceland has performed an analysis of the caffeine content of cola drinks which confirms the reported values given. The caffeine content from chocolate is based on calculations of the content of cocoa in the product. For tea and coffee, published analysed values were used. An overview of the caffeine content in different foods and beverages used in this report is shown in Table 7. 
Table 7. Caffeine content in different foods and beverages used in this report ( $\mathrm{mg} / \mathbf{1 0 0 \mathrm { g }}$ )

\begin{tabular}{|c|c|c|c|c|c|}
\hline & Denmark & Finland & Iceland & Norway & Sweden \\
\hline Food Item & $\mathrm{mg} / 100 \mathrm{~g}$ & $\mathrm{mg} / 100 \mathrm{~g}$ & $\mathrm{mg} / 100 \mathrm{~g}$ & $\mathrm{mg} / 100 \mathrm{~g}$ & $\mathrm{mg} / 100 \mathrm{~g}$ \\
\hline Cola & 13 & 13 & 13 & 13 & 13 \\
\hline Energy drink & 15 & 32 & 15 & 15 & 32 \\
\hline Coffee & 50 & 50 & 55 & 50 & 69 \\
\hline Tea & 16 & 15 & 17 & 16 & 24 \\
\hline Chocolate (light/dark) & & & & 38 & \\
\hline "Milk chocolate" & & & & & 15 \\
\hline Cocoa & & & & & 2.3 \\
\hline Chocolate drink & 2 & & 2 & & 1.5 \\
\hline Chocolate cakes & & & & & 20 \\
\hline Chocolate desserts & & & & & 14.6 \\
\hline Dark chocolate & & & & & 65 \\
\hline
\end{tabular}

The somewhat different values used by each country are due to different use of literature data. The differences in the content of caffeine in energy drinks are due to different legislation in the Nordic countries. The only country that has analysed caffeine in cola drinks is Iceland. Their value confirms the literature and supplier data (Umhverfisstofnun 2006).

\subsection{Denmark}

\subsubsection{Trends in the consumption of caffeinated beverages}

Danish consumers have approximately doubled their consumption of soft drinks during the last 20 years. Table D1 illustrates the increase in sales figures from 51 litres per capita in 1985 to 102 litres per capita in 2005 .

Table D1. Sales figures for soft drinks (litres per capita) in Denmark

\begin{tabular}{lrrrrrrrrr}
\hline Soft drink sales & 1985 & 1990 & 1995 & 2000 & 2001 & 2002 & 2003 & 2004 & 2005 \\
\hline Litres/capita/year & 51 & 58 & 89 & 95 & 96 & 96 & 100 & 100 & 102 \\
\hline
\end{tabular}

Source: Danish Brewers Association: http://www.bryggeriforeningen.dk/

\subsubsection{Consumption of caffeine-containing foods and beverages among}

Danish children and adolescents

Consumption data

A national food survey was carried out from June 2000-December 2002, with 4120 participants, 4-75 years old (Danmarks Fødevareforskning 2005). The participants filled in questionnaires containing background information, and the method of the survey was optically readable food diaries, filled in over 7 consecutive days. Interviews and the handing out of questionnaires were done by the Danish National Institute of Social Research. The filled diaries were returned to and analysed at the National Food Institute. Participants were chosen by random samples from the national register of civil registration numbers. Non-Danish citizens and people living in institutions were excluded from the survey. The partici- 
pants were considered to represent the Danish population in the best way regarding sex and age-group distribution, level of education and geographical distribution.

For this report, data on consumption of caffeine-containing beverages have been analysed and the results from the 545 participating children and adolescents, 4-18 years of age are reported. The number of children in each age group varies between 22 and 60 (see Table D3).

The relevant caffeine-containing beverages are coffee, tea, soft drinks and chocolate milk, and the mean daily consumption is shown in Figure D1. There is no available information on the consumption of energy drinks in Danish adolescents. The soft drink consumption in the food diaries was not divided into cola/-non-cola drinks. Sales figures from the Danish brewers association show that in $2005,64 \%$ of sold soft drinks were cola. We don't know if this preference is also the case for children. Therefore caffeine intake per kg body weight per day, has been calculated both under the assumption that all soft drinks are cola, and a calculation where $60 \%$ of the consumed soft drinks are cola.

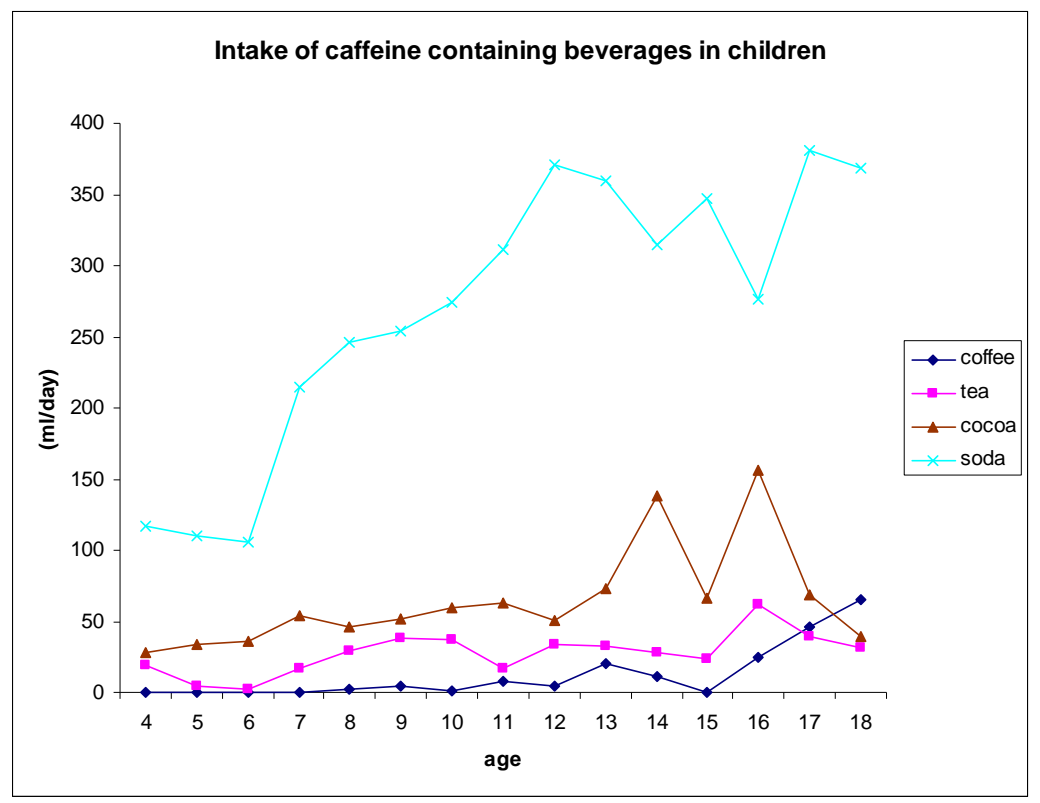

Figure D1. Consumption of caffeine-containing beverages (average consumption for all participants in all age groups).

Figure D1 confirms that the beverage consumed in the highest amount is soft drinks. In all age groups, this is by far the most commonly consumed caffeine-containing drink. Table D3 shows that there are less than $10 \%$ of Danish children who never consume cola drinks.

Table D2 gives more detailed insight into the consumption patterns of chocolate, tea and coffee. Half the children drink chocolate milk regularly, while only $25 \%$ drink tea and very few consume coffee before they are 13 years old. After this age, the percentage of coffee consumers gradually increases. 
Table D2. The table shows the mean and percentiles of the consumption of soft drinks, coffee, tea and chocolate milk among Danish children and adolescents aged from 4 to 18 years.

\begin{tabular}{|c|c|c|c|c|c|c|c|c|c|}
\hline \multicolumn{10}{|c|}{ All participants } \\
\hline \multirow[t]{2}{*}{ Age } & \multirow[t]{2}{*}{ Type of drink } & \multirow{2}{*}{$\begin{array}{l}\text { Mean } \\
\text { ml/day }\end{array}$} & \multirow[t]{2}{*}{ SD } & \multicolumn{6}{|c|}{ Percentiles } \\
\hline & & & & 10 & 25 & 50 & 75 & 90 & 95 \\
\hline 4 & & 117 & 95 & 21 & 46 & 91 & 166 & 257 & 298 \\
\hline 5 & & 110 & 97 & 0 & 38 & 68 & 193 & 257 & 301 \\
\hline 6 & & 106 & 75 & 21 & 43 & 88 & 171 & 204 & 239 \\
\hline 7 & & 214 & 194 & 51 & 86 & 136 & 293 & 469 & 539 \\
\hline 8 & & 246 & 212 & 49 & 107 & 179 & 336 & 449 & 715 \\
\hline 9 & & 254 & 201 & 21 & 114 & 221 & 343 & 457 & 550 \\
\hline 10 & Soft drinks, & 274 & 162 & 126 & 157 & 229 & 364 & 444 & 563 \\
\hline 11 & all types & 311 & 224 & 67 & 114 & 275 & 463 & 481 & 747 \\
\hline \multirow[t]{2}{*}{12} & & 371 & 266 & 106 & 157 & 307 & 479 & 817 & 871 \\
\hline & & 359 & 29 & 92 & 146 & 279 & 423 & 661 & 1069 \\
\hline 13 & & & 4 & & & & & & \\
\hline 14 & & 315 & 247 & 0 & 176 & 275 & 413 & 677 & 781 \\
\hline 15 & & 348 & 347 & 6 & 116 & 218 & 564 & 880 & 989 \\
\hline 16 & & 277 & 246 & 0 & 54 & 257 & 407 & 640 & 746 \\
\hline 17 & & 381 & 475 & 31 & 100 & 257 & 443 & 810 & 1067 \\
\hline 18 & & 369 & 326 & 62 & 170 & 311 & 436 & 771 & 885 \\
\hline 4 & & 28 & 42 & 0 & 0 & 7 & 36 & 73 & 115 \\
\hline 5 & & 33 & 56 & 0 & 0 & 11 & 46 & 86 & 109 \\
\hline 6 & & 36 & 43 & 0 & 0 & 18 & 63 & 79 & 114 \\
\hline 7 & & 54 & 76 & 0 & 0 & 0 & 82 & 180 & 209 \\
\hline 8 & & 47 & 59 & 0 & 0 & 29 & 71 & 154 & 171 \\
\hline 9 & & 51 & 68 & 0 & 0 & 29 & 86 & 143 & 143 \\
\hline 10 & Chocolate milk & 59 & 82 & 0 & 0 & 29 & 86 & 149 & 190 \\
\hline 11 & & 62 & 72 & 0 & 0 & 57 & 107 & 143 & 171 \\
\hline 12 & & 50 & 93 & 0 & 0 & 0 & 86 & 143 & 194 \\
\hline 13 & & 73 & 88 & 0 & 0 & 43 & 114 & 174 & 200 \\
\hline 14 & & 138 & 271 & 0 & 0 & 43 & 196 & 249 & 503 \\
\hline 15 & & 66 & 83 & 0 & 7 & 29 & 100 & 169 & 226 \\
\hline 16 & & 156 & 268 & 0 & 0 & 71 & 200 & 283 & 493 \\
\hline 17 & & 69 & 103 & 0 & 0 & 29 & 86 & 246 & 265 \\
\hline 18 & & 39 & 77 & 0 & 0 & 0 & 29 & 140 & 184 \\
\hline 4 & & 19 & 41 & 0 & 0 & 0 & 25 & 71 & 71 \\
\hline 5 & & 4 & 18 & 0 & 0 & 0 & 0 & 1 & 15 \\
\hline 6 & & 2 & 7 & 0 & 0 & 0 & 0 & 0 & 16 \\
\hline 7 & & 17 & 68 & 0 & 0 & 0 & 0 & 29 & 66 \\
\hline 8 & & 29 & 76 & 0 & 0 & 0 & 29 & 69 & 159 \\
\hline 9 & & 38 & 66 & 0 & 0 & 0 & 57 & 114 & 171 \\
\hline 10 & Tea & 37 & 101 & 0 & 0 & 0 & 29 & 80 & 206 \\
\hline 11 & & 17 & 32 & 0 & 0 & 0 & 21 & 57 & 86 \\
\hline 12 & & 33 & 62 & 0 & 0 & 0 & 29 & 126 & 171 \\
\hline 13 & & 32 & 81 & 0 & 0 & 0 & 29 & 60 & 149 \\
\hline 14 & & 28 & 54 & 0 & 0 & 0 & 29 & 77 & 163 \\
\hline 15 & & 23 & 40 & 0 & 0 & 0 & 29 & 86 & 113 \\
\hline 16 & & 62 & 152 & 0 & 0 & 0 & 57 & 160 & 340 \\
\hline 17 & & 39 & 72 & 0 & 0 & 0 & 29 & 149 & 171 \\
\hline 18 & & 31 & 53 & 0 & 0 & 0 & 57 & 109 & 140 \\
\hline 4 & & 0 & 1 & 0 & 0 & 0 & 0 & 0 & 0 \\
\hline 5 & & 0 & 0 & 0 & 0 & 0 & 0 & 0 & 0 \\
\hline 6 & & 0 & 0 & 0 & 0 & 0 & 0 & 0 & 0 \\
\hline 7 & & 0 & 0 & 0 & 0 & 0 & 0 & 0 & 0 \\
\hline 8 & & 2 & 7 & 0 & 0 & 0 & 0 & 0 & 20 \\
\hline 9 & & 4 & 23 & 0 & 0 & 0 & 0 & 0 & 0 \\
\hline 10 & Coffee & 1 & 5 & 0 & 0 & 0 & 0 & 0 & 0 \\
\hline 11 & & 8 & 33 & 0 & 0 & 0 & 0 & 9 & 29 \\
\hline 12 & & 4 & 17 & 0 & 0 & 0 & 0 & 0 & 17 \\
\hline 13 & & 20 & 79 & 0 & 0 & 0 & 0 & 31 & 73 \\
\hline 14 & & 11 & 46 & 0 & 0 & 0 & 0 & 0 & 57 \\
\hline 15 & & 0 & 0 & 0 & 0 & 0 & 0 & 0 & 0 \\
\hline 16 & & 25 & 108 & 0 & 0 & 0 & 0 & 26 & 80 \\
\hline 17 & & 55 & 139 & 0 & 0 & 0 & 29 & 156 & 194 \\
\hline 18 & & 65 & 187 & 0 & 0 & 0 & 12 & 140 & 444 \\
\hline
\end{tabular}


To be able to compare the data between the Nordic countries, the Danish data for soft drink consumption have been pooled into age groups (4-6-, 7-9-, 10-13- and 14-18-year-olds), and data have been analysed both for all participants and for consumers only. The distribution of cola drink consumers and non-consumers, divided into the abovementioned age groups is shown in Table D3.

Table D3. The distribution of cola drink consumers and non-consumers among all children participating in the survey (divided into age groups)

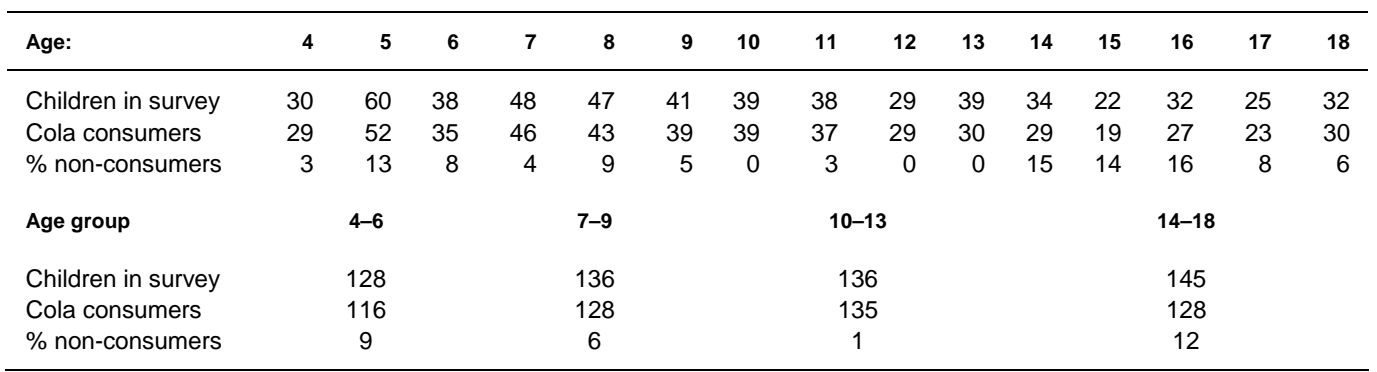

The Tables D4 and D5 show the levels of soft drink consumption in Danish children 4 to 13 years old, Table D4 including all children in the survey, while D5 only includes the consumers. The intakes are rather similar in the two groups because the number of non-consumers is very small. The mean intake increases with age group, starting at $110 \mathrm{ml} /$ day among the youngest and increasing to more than $300 \mathrm{ml} /$ day among the oldest (Table D4). Among the 10-13-year-old high-consumers (95 percentile), $835 \mathrm{ml} /$ day or more is consumed (Table D5).

Table D4. Consumption of soft drinks among Danish children and adolescents (divided into age groups). The numbers include all participants in the investigation

\begin{tabular}{|c|c|c|c|c|c|c|c|c|c|}
\hline \multicolumn{10}{|c|}{ All participants } \\
\hline \multirow{2}{*}{$\begin{array}{l}\text { Age } \\
\text { group }\end{array}$} & \multirow{2}{*}{$\begin{array}{l}\text { Type of } \\
\text { drink }\end{array}$} & \multirow{2}{*}{$\begin{array}{l}\text { Mean } \\
\text { ml/day }\end{array}$} & \multirow[t]{2}{*}{ SD } & \multicolumn{6}{|c|}{ Percentiles } \\
\hline & & & & 10 & 25 & 50 & 75 & 90 & 95 \\
\hline 4-6 years & Normal & 110 & 90 & 18 & 43 & 86 & 171 & 252 & 293 \\
\hline $7-9$ years & soft drink & 237 & 201 & 46 & 93 & 179 & 343 & 461 & 632 \\
\hline $10-13$ years & + light & 324 & 236 & 98 & 150 & 264 & 430 & 621 & 834 \\
\hline
\end{tabular}

Table D5. Consumption of soft drinks among Danish children and adolescents (divided into age groups). The numbers include consumers only.

\begin{tabular}{|c|c|c|c|c|c|c|c|c|c|c|}
\hline \multicolumn{11}{|c|}{ Consumers only } \\
\hline \multirow{2}{*}{$\begin{array}{l}\text { Age } \\
\text { group }\end{array}$} & \multirow[t]{2}{*}{ N (\%) } & \multirow{2}{*}{$\begin{array}{l}\text { Type of } \\
\text { drink }\end{array}$} & \multirow{2}{*}{$\begin{array}{c}\text { Mean } \\
\text { ml/day }\end{array}$} & \multirow[t]{2}{*}{ SD } & \multicolumn{6}{|c|}{ Percentiles } \\
\hline & & & & & 10 & 25 & 50 & 75 & 90 & 95 \\
\hline $4-6$ years & $116(91)$ & Normal & 122 & 87 & 21 & 64 & 96 & 177 & 257 & 300 \\
\hline 7-9 years & $128(94)$ & soft drink & 252 & 199 & 57 & 114 & 193 & 343 & 469 & 684 \\
\hline $10-13$ years & 135 (99) & + light & 326 & 236 & 100 & 154 & 264 & 432 & 621 & 835 \\
\hline
\end{tabular}




\subsubsection{Exposure to caffeine among Danish children and adolescents}

Table D6 shows the mean intake of caffeine among 5-, 8-, 12- and 16year-old children in Denmark, given the assumption that all consumed soft drink is cola. In reality, probably very few belong to this category. Thus the table represents a worst case scenario. The total intake is given as $\mathrm{mg} /$ day and intake from the different sources is shown.

Table D6. Intake of caffeine from different sources (\% of total intake)

\begin{tabular}{|c|c|c|c|c|c|}
\hline All participants & & & & & \\
\hline \multirow[t]{3}{*}{ Age groups } & $\begin{array}{r}\text { Total caffeine } \\
\text { intake }\end{array}$ & Cola drinks & Coffee & Tea & Chocolate mill \\
\hline & Mean (mg/day) & (mg/day) & (mg/day) & (mg/day) & (mg/day \\
\hline & & $\begin{array}{r}13 \mathrm{mg} \\
\text { caffeine/dl }\end{array}$ & $\begin{array}{r}50 \mathrm{mg} \\
\text { caffeine/dl }\end{array}$ & $\begin{array}{r}16 \mathrm{mg} \\
\text { caffeine/dl }\end{array}$ & $\begin{array}{r}2 \mathrm{mg} \\
\text { caffeine/d }\end{array}$ \\
\hline 5 years (4-6) & 16.2 & 14.4 (89) & $0.0(0)$ & $1.1(7)$ & $0.7(4)$ \\
\hline 8 years $(7-9)$ & 37.2 & $30.8(83)$ & $1.0(3)$ & $4.4(11)$ & $1.0(3)$ \\
\hline 12 years $(10-13)$ & 51.9 & 42.1 (82) & $3.8(7)$ & $4.7(9)$ & $1.2(2)$ \\
\hline 16 years (14-18) & 68.2 & $43.5(64)$ & $16.8(25)$ & $6.0(8)$ & $2.0(3)$ \\
\hline
\end{tabular}

Another source of caffeine is chocolate. Unfortunately we do not have chocolate intake data divided into age groups, so this information is not included into the calculation of caffeine consumption in the tables and figures. The mean consumption of sweets (chocolate and candy) in Danish children is $29 \mathrm{~g}$ /day - more in the weekends, less on weekdays. Less than $50 \%$ of the $29 \mathrm{~g}$ is chocolate, but since the $29 \mathrm{~g}$ does not include chocolate cake, cookies, chocolate puddings, nutella, and chocolate bread spreads, an estimate of $15 \mathrm{~g}$ of chocolate a day is probably not unrealistic. If the blend of light and dark chocolate that the children consume contains $20 \mathrm{mg}$ of caffeine per $100 \mathrm{~g}$, then Danish children get around $3 \mathrm{mg}$ of caffeine extra a day - from sources other than coffee, tea, soft drinks and chocolate milk. 


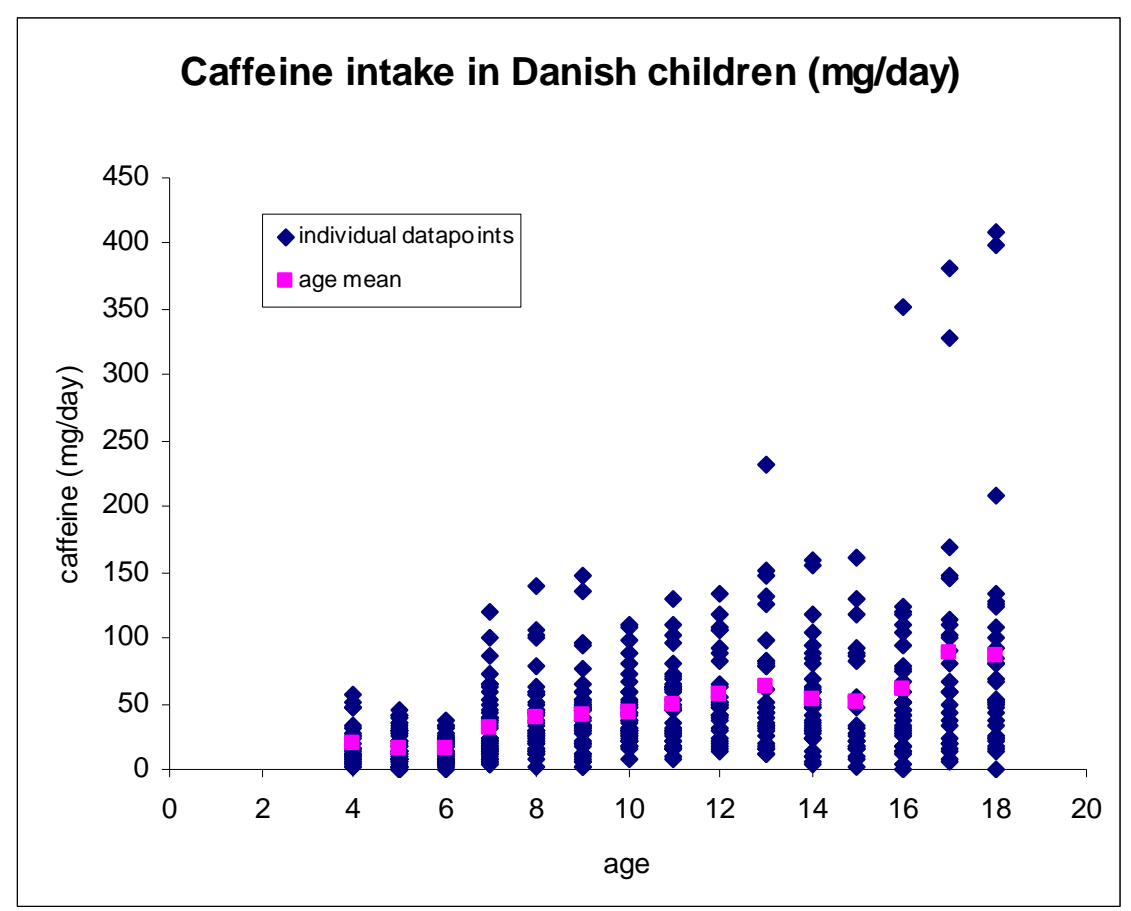

Figure D2. Caffeine intake in Danish children (mg/day)

Figure D2 shows the intake ranges of caffeine per day in the various age groups. The most extreme outliers are seen in the oldest age groups.

\subsubsection{Caffeine exposure per $\mathrm{kg}$ body weight in Danish children and adolescents}

Table D7 shows the caffeine intake in Danish children per kg bw per day, using the assumption that all soft drinks are cola. The mean intake ranged from $0.7 \mathrm{mg} / \mathrm{kg}$ bw/day in 6-year-olds to $1.6 \mathrm{mg} / \mathrm{kg}$ bw/day in 17 -yearolds. The caffeine intake at the 95 percentile ranged from $1.6-5.4 \mathrm{mg} / \mathrm{kg}$ bw/day.

The Danish children's mean daily caffeine intake is shown in the tables and figures below as the sum of all caffeine (including contributions from both soft drinks and other caffeine-containing beverages). These data can not be directly compared to the caffeine consumption data in the tables from the other Nordic countries (F6, I7 \& 8, N6, $7 \& 8$ and S8) which show how the caffeine intake of the different caffeine containing beverages is distributed - rather than the total daily consumption from all sources at the same time. However, comparisons between caffeine consumption data in the Nordic countries (calculated on the same premises) are shown in chapter 3.8 of the report. 
Table D7. Intake of caffeine (per day and per kg body weight/day) in the different age groups of Danish children and adolescents, given that all soft drinks consumed are cola drinks.

\begin{tabular}{|c|c|c|c|c|c|c|c|c|c|c|}
\hline \multicolumn{11}{|c|}{ All participants } \\
\hline \multirow[t]{2}{*}{ Age } & \multirow{2}{*}{$\begin{array}{r}\text { Mean } \\
\text { mg/day }\end{array}$} & \multirow[t]{2}{*}{ SD } & \multicolumn{2}{|l|}{ Mean } & \multicolumn{6}{|c|}{ Percentiles } \\
\hline & & & $\mathrm{mg} / \mathrm{kg}$ bw/day & SD & 10 & 25 & 50 & 75 & 90 & 95 \\
\hline 4 years & 19.0 & 15.2 & 1.1 & 0.9 & 0.2 & 0.5 & 0.9 & 1.5 & 2.8 & 2.9 \\
\hline 5 years & 15.6 & 12.6 & 0.8 & 0.7 & 0.1 & 0.3 & 0.7 & 1.4 & 1.8 & 2.1 \\
\hline 6 years & 14.8 & 9.8 & 0.7 & 0.5 & 0.2 & 0.3 & 0.6 & 1.1 & 1.3 & 1.6 \\
\hline 7 years & 31.6 & 26.1 & 1.2 & 1.0 & 0.3 & 0.5 & 0.8 & 1.5 & 2.4 & 3.0 \\
\hline 8 years & 38.4 & 28.5 & 1.5 & 1.1 & 0.5 & 0.8 & 1.1 & 1.9 & 2.8 & 4.0 \\
\hline 9 years & 42.2 & 32.1 & 1.5 & 1.1 & 0.2 & 0.7 & 1.3 & 1.8 & 2.7 & 3.5 \\
\hline 10 years & 43.1 & 25.9 & 1.4 & 0.8 & 0.6 & 0.8 & 1.2 & 1.7 & 2.7 & 3.2 \\
\hline 11 years & 48.2 & 29.9 & 1.4 & 0.9 & 0.4 & 0.7 & 1.4 & 1.8 & 2.5 & 3.0 \\
\hline 12 years & 56.6 & 33.6 & 1.5 & 0.9 & 0.5 & 0.9 & 1.3 & 2.2 & 2.8 & 2.9 \\
\hline 13 years & 63.4 & 51.5 & 1.5 & 1.2 & 0.4 & 0.7 & 1.1 & 1.9 & 3.1 & 3.6 \\
\hline 14 years & 53.6 & 38.9 & 1.1 & 0.8 & 0.2 & 0.6 & 1.0 & 1.4 & 2.1 & 2.7 \\
\hline 15 years & 50.3 & 45.1 & 0.9 & 0.8 & 0.2 & 0.3 & 0.5 & 1.6 & 2.1 & 2.4 \\
\hline 16 years & 61.4 & 63.8 & 1.1 & 1.1 & 0.2 & 0.5 & 0.8 & 1.3 & 1.9 & 2.3 \\
\hline 17 years & 89.1 & 93.1 & 1.6 & 1.7 & 0.2 & 0.4 & 1.1 & 1.8 & 2.7 & 5.4 \\
\hline 18 years & 86.5 & 94.6 & 1.5 & 1.6 & 0.3 & 0.5 & 1.0 & 1.6 & 2.5 & 4.6 \\
\hline
\end{tabular}

Since a very large part of the caffeine intake in children and adolescents comes from soft drinks, the intake is probably overestimated in most of the participants. Estimates based on the total population indicate that $60-65 \%$ of the total consumption is cola drinks. In Figures D3a and D3b this difference in caffeine intake estimation is illustrated.
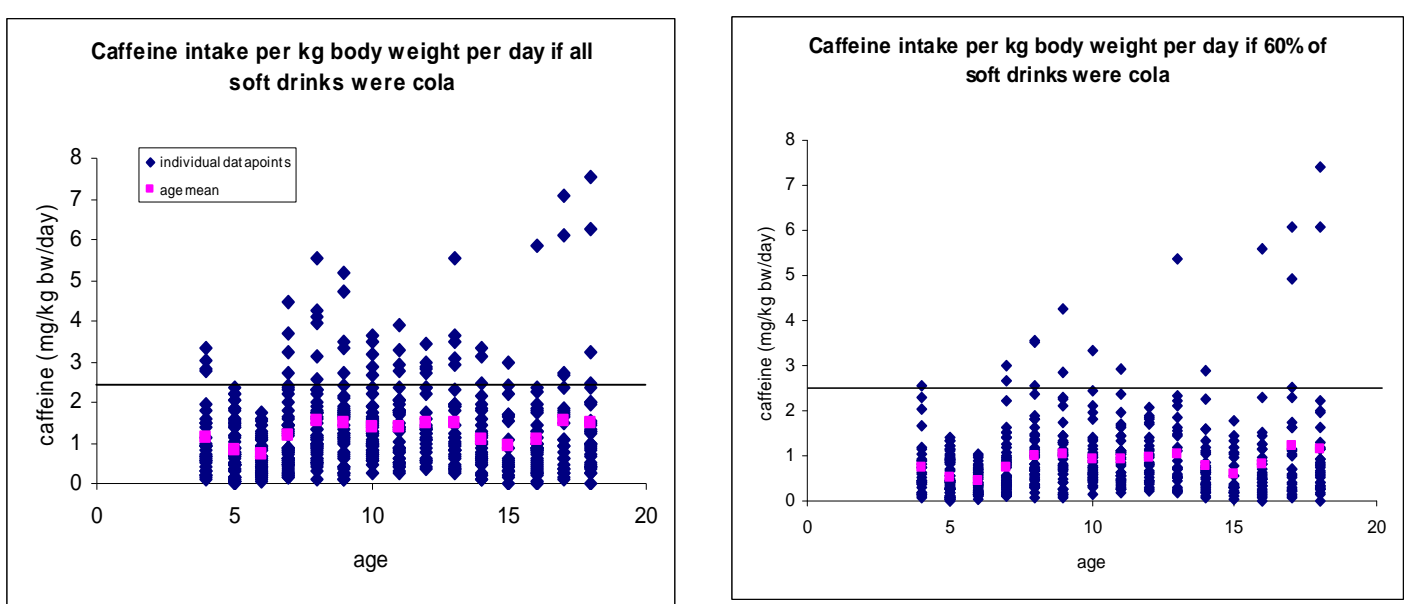

Figure D3a and D3b: Caffein intake per $\mathrm{kg}$ bw/day, if all soft drinks were cola drinks (a) and if $60 \%$ of all soft drinks were cola drinks (b) 


\subsection{Finland}

\subsubsection{Trends in the consumption of caffeinated beverages}

The sales figures for soft drinks almost doubled in Finland between 1980 and 2006 (Table F1). In the years 2004-2006, the consumption of cola beverages was about 61 litres per person, cola beverages comprising about $40 \%$ of the total market of soft drinks. The consumption patterns of coffee and tea seem more stable even though a yearly variation can be seen in the sales figures of coffee. The coffee consumption was highest in 1980 and 1990 (164 litres per capita) and in the years 2004-2006 (156 litres per capita). The consumption of tea has slightly increased during this millennium. When considering the times series of sales figures, it is, however, important to keep in mind that the calculation bases might have slightly changed during the years. In addition, the sales figures for soft drinks do not include sales by vendors that are not members of the Federation of the Brewing and Soft Drinks Industry, except for 2006.

Table F1. Sales figures for soft drinks, coffee and tea (litres per capita) in Finland

\begin{tabular}{lrrrrrrrrrr}
\hline Beverage & $\mathbf{1 9 8 0}$ & $\mathbf{1 9 9 0}$ & $\mathbf{1 9 9 5}$ & $\mathbf{2 0 0 0}$ & $\mathbf{2 0 0 1}$ & $\mathbf{2 0 0 2}$ & $\mathbf{2 0 0 3}$ & $\mathbf{2 0 0 4}$ & $\mathbf{2 0 0 5}$ & $\mathbf{2 0 0 6}$ \\
\hline Soft drink & 30.9 & 41.9 & 45.8 & 56.9 & 57.3 & 59.8 & 56.9 & 61 & 60.5 & 61 \\
Coffee $^{\star}$ & 164.8 & 163.2 & 132.8 & 147.2 & 145.6 & 124.8 & 140.8 & 156.8 & 156.3 & 156.6 \\
Tea $^{\star \star}$ & 8.8 & 8.8 & 8.8 & 8.8 & 8.8 & 8.4 & 9.4 & 9.9 & 12.8 & 10.8 \\
\hline
\end{tabular}

Source: Federation of the Brewing and Soft Drinks Industry: http://www.panimoliitto.fi/panimoliitto/en

* Coffee: 16 litres of ready to drink coffee $=1 \mathrm{~kg}$ coffee beans

** Tea: 44 litres ready to drink tea $=1 \mathrm{~kg}$ tea leaves

\subsubsection{Consumption of caffeine-containing beverages among Finnish adolescents}

Consumption data

The consumption data from the Special Turku Coronary Risk Factor Intervention Project (STRIP) are used to estimate caffeine exposure among Finnish 14-and 15-year-old teenagers (Niinikoski 2007; Simell 2000). The main purpose of the STRIP-study has been prevention of coronary heart disease and atherosclerosis using nutritional and life-style counselling. The study began in infancy and will continue through the years of puberty to young adulthood. The nutritional counselling aimed to help the child and family to modify their diet close to national nutrition recommendations (fat $30 \mathrm{E} \%$, unsaturated to saturated fatty-acid ratio of $2: 1$ ). A fixed diet was never ordered. The life-style counselling comprised primary prevention of smoking and obesity and advancement of physical activity in sedentary children. Children were recruited to the STRIP study between 1989 and 1992. At the age of 7 months, they were randomised to the intervention $(n=540)$ or the control group $(n=522)$. Intervention families met with the counselling team at 1 - to 3 -month intervals until the 
age of the child was 2 years, and biannually thereafter. The control children were seen biannually until they were 7 years and thereafter only once a year. Nutritional data were collected once a year from both control and intervention subjects using four consecutive days of food records, including one weekend day. The ages of the children are now (2007) between 15 and 17 years. Today 550 children remain active in the study.

For this report, a database on a total of 494 children at the age of 14 years in 2003-2005 and 468 of the same children at the age of 15 years in 2004-2006 has been analysed. The data for the control (55\% of total group) and intervention ( $45 \%$ of total group) groups are presented together. The results of possible intervention effects will be published later in more detail by the STRIP-project group.

The caffeine-containing drinks consumed by the STRIP-study children were cola drinks, energy drinks, coffee and tea, and their consumption among the whole group (Table F2) and among the consumers only (Table F3) is shown. Cola drinks were the most consumed caffeinecontaining drink followed by tea, coffee and energy drinks (Table F2). The mean consumption of cola drinks among all 14- and 15-year-old teenagers was 87 and $76 \mathrm{ml}$ per day, respectively. Among the almost $50 \%$, who were consumers, the mean consumption of cola drinks was twice as high (185 and $176 \mathrm{ml}$, Table F3). Only 3\% of the teenagers consumed so-called energy drinks, the mean daily consumption varying from 166 (14-year-olds) to 184 (15-year-olds) $\mathrm{ml}$. The coffee drinkers comprised approximately $20 \%$ and tea drinkers $28 \%$ of the total group. Among the coffee drinkers, the mean consumption of coffee ranged from 106 (14-year-olds) to 134 (15-year-olds) ml/day. The mean consumption of tea was $146 \mathrm{ml} /$ day.

Table F2. Consumption of cola drinks, energy drinks, coffee and tea among Finnish adolescents. The numbers include all the adolescents in the investigation

\begin{tabular}{|c|c|c|c|c|c|c|c|c|c|c|c|}
\hline \multicolumn{12}{|c|}{ All participants } \\
\hline \multirow[t]{2}{*}{ Age } & \multirow[t]{2}{*}{$\mathrm{N}$} & \multirow{2}{*}{$\begin{array}{l}\text { Type of } \\
\text { drink }\end{array}$} & \multirow{2}{*}{$\begin{array}{l}\text { Mean } \\
\text { ml/day }\end{array}$} & \multirow[t]{2}{*}{ SD } & \multicolumn{7}{|c|}{ Percentiles } \\
\hline & & & & & 5 & 10 & 25 & 50 & 75 & 90 & 95 \\
\hline 14 years & 494 & Cola & 87 & 147 & 0 & 0 & 0 & 0 & 125 & 263 & 350 \\
\hline 15 years & 468 & & 76 & 126 & 0 & 0 & 0 & 0 & 113 & 250 & 325 \\
\hline 14 years & 494 & Energy & 5 & 32 & 0 & 0 & 0 & 0 & 0 & 0 & 0 \\
\hline 15 years & 468 & Drinks* & 5 & 58 & 0 & 0 & 0 & 0 & 0 & 0 & 0 \\
\hline 14 years & 494 & Coffee & 18 & 59 & 0 & 0 & 0 & 0 & 0 & 50 & 113 \\
\hline 15 years & 468 & & 29 & 77 & 0 & 0 & 0 & 0 & 0 & 100 & 200 \\
\hline 14 years & 494 & Tea & 41 & 106 & 0 & 0 & 0 & 0 & 50 & 150 & 225 \\
\hline 15 years & 468 & & 40 & 90 & 0 & 0 & 0 & 0 & 40 & 150 & 250 \\
\hline
\end{tabular}

${ }^{*}$ Cola energy drinks + caffeine containing welfare drinks 
Table F3. Consumption of cola drinks, energy drinks, coffee and tea among Finnish adolescents. The numbers include consumers only

\begin{tabular}{|c|c|c|c|c|c|c|c|c|c|c|c|}
\hline \multicolumn{12}{|c|}{ Consumers only } \\
\hline \multirow[t]{2}{*}{ Age } & \multirow[t]{2}{*}{ N (\%) } & \multirow{2}{*}{$\begin{array}{l}\text { Type of } \\
\text { drink }\end{array}$} & \multirow{2}{*}{$\begin{array}{l}\text { Mean } \\
\text { ml/day }\end{array}$} & \multirow[t]{2}{*}{ SD } & \multicolumn{7}{|c|}{ Percentiles } \\
\hline & & & & & 5 & 10 & 25 & 50 & 75 & 90 & 95 \\
\hline 14 years & $232(47)$ & Cola & 185 & 167 & 38 & 50 & 88 & 125 & 250 & 375 & 475 \\
\hline 15 years & 202 (43) & & 176 & 138 & 38 & 50 & 75 & 125 & 238 & 350 & 475 \\
\hline 14 years & $14(3)$ & Energy & 166 & 96 & 63 & 63 & 83 & 125 & 250 & 265 & 375 \\
\hline 15 years & $14(3)$ & drinks* & 184 & 296 & 75 & 83 & 83 & 106 & 125 & 165 & 1208 \\
\hline 14 years & $86(17)$ & Coffee & 106 & 106 & 25 & 25 & 38 & 56 & 143 & 250 & 353 \\
\hline 15 years & $101(22)$ & & 134 & 115 & 25 & 25 & 50 & 98 & 200 & 313 & 350 \\
\hline 14 years & $138(28)$ & Tea & 146 & 157 & 38 & 50 & 63 & 100 & 175 & 288 & 353 \\
\hline 15 years & $128(27$ & & 146 & 118 & 28 & 43 & 50 & 100 & 200 & 325 & 365 \\
\hline
\end{tabular}

Cola energy drinks + caffeine containing welfare drinks

\subsubsection{Exposure to caffeine among Finnish adolescents}

Table F4 shows the intake of caffeine from different sources among 14and 15-year-old Finnish teenagers (all participants). The most important contributors of caffeine were cola drinks and coffee, both accounting for $31-45 \%$ of the total caffeine intake. Tea consumption was also an important source, contributing with $19-22 \%$ of the total caffeine intake. Energy drinks accounted for only $5-6 \%$ of the total caffeine intake.

Table F4. Intake of caffeine from different sources (\% of total intake)

\begin{tabular}{|c|c|c|c|c|c|}
\hline \multicolumn{6}{|c|}{ All participants } \\
\hline Age & $\begin{array}{r}\text { Total caffeine } \\
\text { intake }\end{array}$ & $\begin{array}{r}\text { Cola drinks } \\
\text { mg/day }\end{array}$ & $\begin{array}{r}\text { Energy drinks } \\
\mathrm{mg} / \text { day }\end{array}$ & $\begin{array}{l}\text { Coffee } \\
\text { mg/day }\end{array}$ & $\begin{array}{r}\text { Tea } \\
\text { mg/day }\end{array}$ \\
\hline & & $\begin{array}{r}13 \mathrm{mg} \\
\text { caffeine/dl }\end{array}$ & $\begin{array}{r}32 \mathrm{mg} \\
\text { caffeine/dl }\end{array}$ & $\begin{array}{r}50 \mathrm{mg} / \\
\text { caffeine/dl }\end{array}$ & $\begin{array}{r}15 \mathrm{mg} \\
\text { caffeine/dl }\end{array}$ \\
\hline 14 years & 28.2 & $11.3(40)$ & $1.5(5)$ & $9.2(33)$ & $6.1(22)$ \\
\hline 15 years & 32.1 & $9.9(31)$ & $1.8(6)$ & $14.5(45)$ & $6.0(19)$ \\
\hline
\end{tabular}

Table F5 shows the mean intake of caffeine $(\mathrm{mg} / \mathrm{day})$ and percentiles from different caffeine-containing beverages among 14- and 15-year-old Finnish adolescents (consumers only). The mean intake of caffeine from soft drinks was $23-24 \mathrm{mg} /$ day and the intake at the 95 percentile was 62 $\mathrm{mg} /$ day for both age groups. The highest mean intakes among the consumers only were found for energy drinks and coffee, with intakes ranging from $53-68 \mathrm{mg} /$ day. 
Table F5. Intake of caffeine from different sources. The numbers include consumers only, Finland (STRIP-study)

\begin{tabular}{|c|c|c|c|c|c|c|c|c|c|c|c|c|}
\hline \multicolumn{13}{|c|}{ Consumers only } \\
\hline \multirow[t]{2}{*}{ Age } & \multirow[t]{2}{*}{ N (\%) } & \multirow{2}{*}{$\begin{array}{l}\text { Type of } \\
\text { drink }\end{array}$} & \multirow{2}{*}{$\begin{array}{r}\text { Caffeine } \\
\mathrm{mg} / \mathrm{dl}\end{array}$} & \multirow{2}{*}{$\begin{array}{c}\text { Mean } \\
\text { mg/ day }\end{array}$} & \multirow[t]{2}{*}{ SD } & \multicolumn{7}{|c|}{ Percentiles } \\
\hline & & & & & & 5 & 10 & 25 & 50 & 75 & 90 & 95 \\
\hline 14 years & $232(47)$ & Cola & 13 & 24 & 22 & 5 & 7 & 11 & 16 & 33 & 49 & 62 \\
\hline 15 years & $202(43)$ & drinks & & 23 & 18 & 5 & 7 & 10 & 16 & 31 & 46 & 62 \\
\hline 14 years & $14(3)$ & Energy & 32 & 53 & 31 & 20 & 20 & 26 & 40 & 80 & 85 & 120 \\
\hline 15 years & $14(3)$ & drinks* & & 59 & 95 & 24 & 26 & 26 & 34 & 40 & 53 & 386 \\
\hline 14 years & $86(17)$ & Coffee & 50 & 53 & 53 & 13 & 13 & 19 & 28 & 71 & 125 & 176 \\
\hline 15 years & $101(22)$ & & & 68 & 57 & 13 & 13 & 25 & 49 & 100 & 156 & 175 \\
\hline 14 years & $138(28)$ & Tea & 15 & 22 & 24 & 6 & 8 & 9 & 15 & 26 & 43 & 53 \\
\hline 15 years & $128(27)$ & & & 22 & 18 & 4 & 6 & 8 & 15 & 30 & 49 & 55 \\
\hline
\end{tabular}

${ }^{\star}$ Cola energy drinks + caffeine containing welfare drinks

\subsubsection{Caffeine exposure per $\mathrm{kg}$ body weight in Finnish adolescents}

As seen before, the mean consumption of cola drinks among the 14- and 15 -year-old consumers (slightly below $50 \%$ of the total group) was approximately $2 \mathrm{dl}$ cola per day (Table F3). The mean intake of caffeine only from cola drinks was correspondingly $0.4 \mathrm{mg} / \mathrm{kg}$ bw/day. The daily intake of caffeine from cola drinks and tea remained below $1.2 \mathrm{mg} / \mathrm{kg}$ bw/day among all consumers (Table F6). Among energy drink- and coffee-consumers, the mean caffeine intake was $2-3$ times higher $(1 \mathrm{mg} / \mathrm{kg}$ bw/day). Five percent of the participants had a caffeine intake from energy drinks or coffee that exceeded $2.5 \mathrm{mg} / \mathrm{kg}$ bw/day (Table F6). Because only $3 \%$ of the total group drank energy drinks, this high intake affected very few individuals. Coffee drinkers comprised $17-20 \%$ of the total group, indicating that coffee consumption was an important contributor to the caffeine intake.

Table F6. Intake of caffeine from the different caffeine-containing drinks (per day and per kg body weight) in Finnish 14- and 15-year-olds. The numbers include consumers only

\begin{tabular}{|c|c|c|c|c|c|c|c|c|c|c|c|c|c|}
\hline \multicolumn{14}{|c|}{ Consumers only } \\
\hline \multirow[t]{2}{*}{ Age } & \multirow[t]{2}{*}{ N (\%) } & \multirow{2}{*}{$\begin{array}{l}\text { Type of } \\
\text { drink }\end{array}$} & \multirow{2}{*}{$\begin{array}{r}\text { Mean } \\
\text { mg/day }\end{array}$} & \multirow[t]{2}{*}{ SD } & \multirow{2}{*}{$\begin{array}{r}\text { Mean } \\
\mathrm{mg} / \mathrm{kg} \\
\text { bw/day }\end{array}$} & \multirow[t]{2}{*}{ SD } & \multicolumn{7}{|c|}{ Percentiles } \\
\hline & & & & & & & 5 & 10 & 25 & 50 & 75 & 90 & 95 \\
\hline 14 years & $231(47)$ & Cola & 24 & 22 & 0.4 & 0.4 & 0.1 & 0.1 & 0.2 & 0.3 & 0.6 & 0.9 & 1.2 \\
\hline 15 years & 202 (43) & drinks & 23 & 18 & 0.4 & 0.3 & 0.1 & 0.1 & 0.2 & 0.3 & 0.5 & 0.8 & 0.9 \\
\hline 14 years & $14(3)$ & Energy & 53 & 31 & 1.0 & 0.6 & 0.3 & 0.4 & 0.5 & 0.8 & 1.3 & 2.0 & 2.3 \\
\hline 15 years & $14(3)$ & drinks* & 59 & 95 & 1.0 & 1.3 & 0.4 & 0.4 & 0.5 & 0.6 & 0.8 & 0.9 & 5.6 \\
\hline 14 years & $86(17)$ & Coffee & 53 & 53 & 1.0 & 1.0 & 0.2 & 0.2 & 0.3 & 0.5 & 1.3 & 2.2 & 3.4 \\
\hline 15 years & $101(22)$ & & 68 & 57 & 1.1 & 1.0 & 0.2 & 0.2 & 0.4 & 0.7 & 1.6 & 2.5 & 3.0 \\
\hline 14 years & $138(28)$ & Tea & 22 & 24 & 0.4 & 0.5 & 0.1 & 0.1 & 0.2 & 0.3 & 0.5 & 0.8 & 1.0 \\
\hline 15 years & $128(27)$ & & 22 & 18 & 0.4 & 0.3 & 0.1 & 0.1 & 0.1 & 0.3 & 0.6 & 0.9 & 1.1 \\
\hline
\end{tabular}

${ }^{*}$ Cola energy drinks + caffeine containing welfare drinks 


\subsection{Iceland}

\subsubsection{Trends in the consumption of caffeinated beverages}

The Icelandic consumption of soft drinks increased eightfold from 1950 to 2000 but has been almost constant since then (Table I1). The reason for this is partly that the consumption of bottled water has increased in Iceland the last few years.

Table I1. Sales figures for soft drinks (litres per capita) in Iceland

\begin{tabular}{lccccccccccccc}
\hline Soft drink sales & 1950 & 1960 & 1970 & 1980 & 1985 & 1991 & 1995 & 2000 & 2001 & 2002 & 2003 & 2004 & 2005 \\
\hline $\begin{array}{l}\text { Litres/ capita/ } \\
\text { year }\end{array}$ & 19 & 28 & 41 & 73 & 117 & 130 & 136 & 159 & 147 & 159 & 158 & 156 & 150 \\
\hline
\end{tabular}

Source: The Public Health Institute of Iceland.

\subsubsection{Consumption of caffeine-containing foods and beverages among Icelandic children and adolescents}

Consumption data

The following consumption surveys are used in the exposure assessments from Iceland:

6-year-old children; Study done by the Unit for Nutrition Research, University of Iceland 2002 (not published). 134 children registered their food intake for three days; Thursday, Friday and Saturday or Sunday, Monday and Tuesday. Cola drinks were specified in this survey.

9- and 15-year-old children and adolescents; The Diet of 9- and 15year-old children and adolescents (Tórsdóttir \& Gunnarsdóttir 2006). The survey included 175 children (9-year-olds) and 150 adolescents (15-yearolds). Both genders were equally represented. The dietary assessment method was a 24-hour dietary recall interview taken at school from Monday-Friday. For quantification, participants received a booklet with 4 portions sizes of 49 dishes or foods, in addition to using common household measures. Soft drinks were included, but cola drinks not specified in this survey.

17-year-old adolescents; The Diet of Icelanders (Steingrímsdóttir et al. 2003). A random sample of 2000 people, 15-80 years of age, was drawn from the national register. They represented the Icelandic population and both genders equally. They were divided into four age groups, $15-19,20-39,40-59$ and $60-80$ years old. The age group of 15-19-yearolds consisted of 124 adolescents; 61 girls and 63 boys. The dietary assessment method was a 24-hour interview by telephone. All days of the week were included, except Thursdays. For quantification, participants received a booklet with 4 portions sizes of 49 dishes or foods, in addition to using common household measures. All interviewers were trained for 
the data gathering and coding of interviews. Cola drinks were specified in this survey.

The consumption of caffeine-containing drinks among Icelandic children and adolescents is shown in Table I2 (all participants) and Table I3 (consumers only). Seventeen-year-old adolescents (15-19 years) are the highest soft drink consumers in Iceland, and they are therefore not ideal representatives for caffeine intake among younger children. The soft drink consumption in the food diaries for 9- and 15-year-old children was not divided into cola and non cola drinks or into consumers only. Seventy percent of the total soft drink consumption among 17-year-old adolescents (15-19 years) was cola drinks. Eighty-three percent of their caffeine intake came from cola drinks (Table I6). The exact data for the consumption of cola drinks among 6- and 17-year-old consumers are presented in Table I3.

Table 12. Consumption of soft drinks, energy drinks, coffee, tea and chocolate products among Icelandic children and adolescents. The numbers include all children and adolescents in the investigation

\begin{tabular}{|c|c|c|c|c|c|c|c|c|c|}
\hline \multicolumn{10}{|c|}{ All participants } \\
\hline \multirow[t]{2}{*}{ Age } & \multirow{2}{*}{$\begin{array}{l}\text { Type of } \\
\text { drink/food }\end{array}$} & \multirow{2}{*}{$\begin{array}{l}\text { Mean } \\
\text { ml/day }\end{array}$} & \multirow[t]{2}{*}{ SD } & \multicolumn{6}{|c|}{ Percentiles } \\
\hline & & & & 10 & 25 & 50 & 75 & 90 & 95 \\
\hline 6 years & Cola drinks & 43 & 64 & & & 14 & 61 & 114 & 194 \\
\hline 9 years & Soft drinks & 349 & 301 & 0 & 125 & 300 & 543 & 800 & 960 \\
\hline 15 years & Soft drinks & 553 & 491 & 0 & 232 & 425 & 750 & 1250 & 1450 \\
\hline 17 years & Cola drinks & 460 & 560 & 0 & 0 & 315 & 750 & 1400 & 1500 \\
\hline \multirow[t]{2}{*}{9 years } & Coffee, tea, & & & & & & & & \\
\hline & cocoa & 18 & 42 & 0 & 0 & 0 & 7 & 100 & 117 \\
\hline \multirow[t]{2}{*}{15 years } & Coffee, tea, & & & & & & & & \\
\hline & cocoa & 22 & 57 & 0 & 0 & 0 & 8 & 100 & 138 \\
\hline 17 years & Coffee & 3 & 22 & 0 & 0 & 0 & 0 & 0 & 0 \\
\hline 17 years & Tea & 3 & 19 & 0 & 0 & 0 & 0 & 0 & 0 \\
\hline 17 years & Cocoa & 81 & 342 & 0 & 0 & 0 & 0 & 250 & 375 \\
\hline 17 years & Energy drinks & 4 & 45 & 0 & 0 & 0 & 0 & 0 & 0 \\
\hline 17 years & Chocolate & 7 & 28 & 0 & 0 & 0 & 0 & 9 & 50 \\
\hline
\end{tabular}

Table I3. Consumption of cola drinks among Icelandic children and adolescents (ml/day). The numbers include consumers only.

\begin{tabular}{|c|c|c|c|c|c|c|c|c|c|}
\hline Consumers only & & & & & & & & & \\
\hline \multirow[t]{2}{*}{ Age } & \multirow[t]{2}{*}{$\mathrm{N}(\%)$} & \multirow{2}{*}{$\begin{array}{l}\text { Mean } \\
\text { ml/day }\end{array}$} & \multirow[t]{2}{*}{ SD } & \multicolumn{6}{|c|}{ Percentiles } \\
\hline & & & & 10 & 25 & 50 & 75 & 90 & 95 \\
\hline 6 years & $69(51)$ & 82 & 73 & & & 60 & 88 & 194 & 267 \\
\hline 17 years $(15-19)$ & $72(58)$ & 792 & 526 & 215 & 400 & 600 & 1100 & 1500 & 1770 \\
\hline
\end{tabular}

Soft drinks/cola drinks were the most consumed caffeine-containing beverages in Iceland followed by cocoa and coffee. The mean consumption from cola drinks among all 6- and 17-year-olds was $43 \mathrm{ml}$ and $460 \mathrm{ml}$ per day, respectively (Table I2). Among cola drinkers only, the mean consumption was $70-90 \%$ higher ( 82 and $792 \mathrm{ml}$ per day). While only $10 \%$ of the 6-year-old consumers had an intake of one glass $(2 \mathrm{dl})$ per day, 
more than $50 \%$ of the teenagers had a consumption of three glasses per day or more. Ten percent of Icelandic 17-year-olds drinks 1.5 litres or more of cola drinks per day (Table I3).

\subsubsection{Exposure to caffeine among Icelandic children and adolescents}

The maximum amount of caffeine allowed in soft drinks in Iceland increased from $135 \mathrm{mg} / \mathrm{l}$ to $150 \mathrm{mg} / \mathrm{l}$ in March 2005. In the years 20022003, when these surveys were performed, the mean concentration of caffeine in cola drinks was $11 \mathrm{mg} / \mathrm{dl}$ in Iceland (Verheijen 2008). After the legislation changed, the mean concentration of caffeine in cola drinks has increased to $13 \mathrm{mg} / \mathrm{dl}$ (Umhverfisstofnun 2006). By using $13 \mathrm{mg}$ caffeine per $\mathrm{dl}$ in the calculations, we believe the data are more representative of the exposure to caffeine today.

Table 14. Intake of caffeine from soft and cola drinks among Icelandic children and adolescents. The numbers include all children and adolescents in the investigations

\begin{tabular}{|c|c|c|c|c|c|c|c|c|c|c|}
\hline \multicolumn{11}{|l|}{ All participants } \\
\hline \multirow[t]{2}{*}{ Age } & \multirow[t]{2}{*}{$\mathrm{N}$} & \multirow{2}{*}{$\begin{array}{r}\text { Caffeine } \\
\mathrm{mg} / \mathrm{dl}\end{array}$} & \multirow{2}{*}{$\begin{array}{r}\text { Mean } \\
\text { mg/day }\end{array}$} & \multirow[t]{2}{*}{ SD } & \multicolumn{6}{|c|}{ Percentiles } \\
\hline & & & & & 10 & 25 & 50 & 75 & 90 & 95 \\
\hline 6 years & 134 & 13 & 6 & 8 & 0 & 0 & 2 & 8 & 15 & 25 \\
\hline 9 years & 175 & 13 & 45 & 39 & 0 & 16 & 39 & 71 & 104 & 125 \\
\hline 15 years & 150 & 13 & 72 & 64 & 0 & 30 & 55 & 98 & 163 & 189 \\
\hline 17 years (15-19) & 124 & 13 & 60 & 73 & 0 & 0 & 41 & 98 & 182 & 195 \\
\hline
\end{tabular}

Table I4 shows the mean intake of caffeine (mg/day) and percentiles among 6-, 9-, 15- and 17-year-old children and adolescents in Iceland, given that all soft drink consumption among 9- and 15-year-olds are cola drinks. The caffeine intake among 9- and 15-year-olds shown in Table I4 is overestimated if their caffeine intake pattern is similar to the 17-yearolds. Only $70 \%$ of the total soft drink consumption among 17 -year-old $(15-19)$ adolescents is cola drinks and $83 \%$ of their caffeine intake comes from cola drinks (Table I6).

Table 15. Intake of caffeine from cola drinks among Icelandic children and adolescents. The numbers include consumers only

\begin{tabular}{|c|c|c|c|c|c|c|c|c|c|c|}
\hline Consumers only & & & & & & & & & & \\
\hline \multirow[t]{2}{*}{ Age } & \multirow[t]{2}{*}{ N (\%) } & \multirow{2}{*}{$\begin{array}{l}\text { Caffeine } \\
\mathrm{mg} / \mathrm{dl}\end{array}$} & \multirow{2}{*}{$\begin{array}{r}\text { Mean } \\
\text { mg/day }\end{array}$} & \multirow[t]{2}{*}{ SD } & \multicolumn{6}{|c|}{ Percentiles } \\
\hline & & & & & 10 & 25 & 50 & 75 & 90 & 95 \\
\hline 6 years & $69(51)$ & 13 & 10.7 & 9.5 & & & 7.8 & 11.4 & 25.1 & 34.4 \\
\hline 17 years (15-19) & $72(58)$ & 13 & 103.0 & 68.3 & 28.0 & 52.0 & 78.0 & 143.0 & 195.0 & 230.1 \\
\hline
\end{tabular}

The mean intake of caffeine from cola drinks among all 6- and 17-yearolds participating in the dietary surveys was $6 \mathrm{mg}$ and $60 \mathrm{mg}$ per day, respectively (Table I4).In the group of cola drinkers only, the mean intake 
was $70-80 \%$ higher, equivalent to $10.7 \mathrm{mg} / \mathrm{day}$ among the 6 year-olds and $103 \mathrm{mg} /$ day among the 17-year-olds (Table I5).

Table 16. Intake of caffeine from different sources for Icelandic 17-year-olds (\% of total intake)

\begin{tabular}{|c|c|c|c|c|c|c|c|}
\hline \multicolumn{8}{|c|}{ All participants } \\
\hline \multirow[t]{3}{*}{ Age } & $\begin{array}{l}\text { Total caffeine } \\
\text { intake }\end{array}$ & Cola drinks & $\begin{array}{l}\text { Energy } \\
\text { drinks }\end{array}$ & Coffee & Tea & Cocoa & Chocolate \\
\hline & $\begin{array}{l}\text { Mean } \\
\text { (mg/day) }\end{array}$ & mg/day & mg/day & $\mathrm{mg} / \mathrm{day}$ & mg/day & mg/day & $\mathrm{mg} / \mathrm{day}$ \\
\hline & & $\begin{array}{r}13 \mathrm{mg} \\
\text { caffeine/dl }\end{array}$ & $\begin{array}{r}15 \mathrm{mg} \\
\text { caffeine/dl }\end{array}$ & $\begin{array}{r}55 \mathrm{mg} \\
\text { caffeine/dl }\end{array}$ & $\begin{array}{r}17 \mathrm{mg} \\
\text { caffeine/dl }\end{array}$ & $\begin{array}{r}2.3 \mathrm{mg} \\
\text { caffeine/dl }\end{array}$ & $\begin{array}{r}100 \mathrm{mg} \\
\text { caffeine/dl }\end{array}$ \\
\hline $\begin{array}{l}17 \text { years } \\
(15-19)\end{array}$ & 71.7 & $59.8(83)$ & $0.8(1)$ & $1.7(2)$ & $0.5(1)$ & $1.9(3)$ & 7.0 (10) \\
\hline
\end{tabular}

Table I6 shows the intake of caffeine from different sources among Icelandic 17-year-olds. The intake data from different sources are only presented for the 17-year-olds, as the data among the younger age groups are very scarce. The most important source for the intake of caffeine in Iceland was cola drinks, contributing with more than 83 percent of the total caffeine intake among 17-year-old adolescents.

\subsubsection{Caffeine exposure per $\mathrm{kg}$ body weight in Icelandic children and adolescents}

Table 17. Intake of caffeine from soft drinks (per day and per kg body weight) in Icelandic children and adolescents. The numbers include all participants

\begin{tabular}{|c|c|c|c|c|c|c|c|c|c|c|}
\hline All participants & & & & & & & & & & \\
\hline \multirow[t]{2}{*}{ Age (mean bw) } & \multirow{2}{*}{$\begin{array}{r}\text { Mean } \\
\text { mg/day }\end{array}$} & \multirow[t]{2}{*}{ SD } & \multirow{2}{*}{$\begin{array}{r}\text { Mean } \\
\text { mg/kg } \\
\text { bw/day }\end{array}$} & \multirow[t]{2}{*}{ SD } & \multicolumn{6}{|c|}{ Percentiles } \\
\hline & & & & & 10 & 25 & 50 & 75 & 90 & 95 \\
\hline 6 years $(20 \mathrm{~kg})$ & 6 & 8 & 0.2 & 0.3 & & & 0.1 & 0.4 & 0.7 & 1.3 \\
\hline 9 years $(35 \mathrm{~kg})$ & 45 & 39 & 1.3 & 1.1 & 0 & 0.5 & 1.1 & 2.0 & 3.0 & 3.6 \\
\hline 15 years $(60 \mathrm{~kg})$ & 72 & 64 & 1.2 & 1.1 & 0 & 0.5 & 0.9 & 1.6 & 2.7 & 3.1 \\
\hline $\begin{array}{l}17 \text { years }(15-19) \\
\left(60 \mathrm{~kg}^{\star}\right)\end{array}$ & 60 & 73 & 1.0 & 1.2 & & & 0.7 & 1.6 & 3.0 & 3.3 \\
\hline
\end{tabular}

*Mean body weight of 15 year-old children are also used for 17 -year-oldteenagers. The mean body weight data used in Table 17 and 18 is from the Primary Health Care of the Capital Area in Iceland. (Erlendsdottir RO, the Primary Health Care of the Capital Area in Iceland, personal communication, 2007)

Table $\mathrm{I} 7$ shows the mean caffeine intake and percentiles $(\mathrm{mg} / \mathrm{kg}$ bw/day) from soft drinks among 6-, 9-, 15- and 17-year-old Icelandic children and adolescents. The mean intake ranged from $0.2 \mathrm{mg} / \mathrm{kg}$ bw/day in 6-yearolds to $1.3 \mathrm{mg} / \mathrm{kg} \mathrm{bw} /$ day in 9-year-olds. At least $10 \%$ of the $9-, 15-$ and 17-year-olds have a caffeine intake around $3 \mathrm{mg} / \mathrm{kg}$ bw/day, given that the entire consumption of soft drinks among 9- and 15-year-olds are cola drinks (Table I7). 
Table 18. Intake of caffeine from cola drinks (per day and per $\mathrm{kg}$ body weight/day) in Icelandic children and adolescents. The numbers include consumers only

\begin{tabular}{|c|c|c|c|c|c|c|c|c|c|c|c|}
\hline Consumers only & & & & & & & & & & & \\
\hline \multirow[t]{2}{*}{ Age (mean bw) } & \multirow[t]{2}{*}{ N (\%) } & \multirow{2}{*}{$\begin{array}{r}\text { Mean } \\
\text { mg/day }\end{array}$} & \multirow[t]{2}{*}{ SD } & \multirow{2}{*}{$\begin{array}{l}\text { Mean } \\
\mathrm{mg} / \mathrm{kg} \\
\text { bw/day }\end{array}$} & \multirow[t]{2}{*}{ SD } & \multicolumn{6}{|c|}{ Percentiles } \\
\hline & & & & & & 10 & 25 & 50 & 75 & 90 & 95 \\
\hline 6 years $(20 \mathrm{~kg})$ & $69(51)$ & 10.7 & 9.5 & 0.5 & 0.5 & & & 0.4 & 0.6 & 1.3 & 1.7 \\
\hline 17 years $\left(60 \mathrm{~kg}^{\star}\right)$ & 72 (58) & 103 & 68.3 & 1.7 & 1.1 & 0.5 & 0.9 & 1.3 & 2.4 & 3.3 & 3.8 \\
\hline
\end{tabular}

*Mean body weight of 15 year-old children are also used for 17 -year-oldteenagers. The mean body weight data used in Table 17 and 18 is from the Primary Health Care of the Capital Area in Iceland. (Erlendsdottir RO, the Primary Health Care of the Capital Area in Iceland, personal communication, 2007)

Table I8 shows the mean caffeine intake and percentiles ( $\mathrm{mg} / \mathrm{kg}$ bw/day) from soft drinks among 6- and 17-year-old Icelandic children and adolescents (consumers only). The mean caffeine intakes were 0.5 and $1.7 \mathrm{mg} / \mathrm{kg}$ bw/day for the two age groups, respectively. Five percent of the 17-yearold adolescents have an intake at approximately $3.8 \mathrm{mg} / \mathrm{kg}$ bw/day. According to dietary surveys in Iceland, the mean soft drinks consumption is highest among 15-19-year-olds. The mean intake of caffeine $(\mathrm{mg} / \mathrm{kg}$ bw/day) from cola drinks among all 6- and 17-year-olds participating in the dietary surveys was 0.2 and $1.0 \mathrm{mg} / \mathrm{kg}$ bw/day, respectively (Table I7). In the group of cola drinkers only, the mean consumption was more than double for 6-year-olds and 70\% higher for 17-year-olds, equivalent to 0.5 and $1.7 \mathrm{mg} / \mathrm{kg}$ bw day, respectively (Table I8).

\subsection{Norway}

\subsubsection{Trends in the consumption of caffeinated beverages}

The Norwegian consumption of soft drinks increased from 60 litres per capita in 1980 to 117 litres per capita in 2002. As Table N1 illustrates, the consumption of soft drinks seems to have gone down in recent years. According to figures from the beverage industry, the sales figures for bottled water and water flavoured with intense sweeteners and sugars have increased from 2004 to 2006 (VKM 2007).

Table N1. Sales figures for soft drinks (litres per capita) in Norway

\begin{tabular}{lccccccccccc}
\hline Sof drink sales & 1980 & 1985 & 1991 & 1995 & 2000 & 2001 & 2002 & 2003 & 2004 & 2005 & 2006 \\
\hline $\begin{array}{l}\text { Litres/capita/ } \\
\text { year }\end{array}$ & 60 & & 82 & 111 & 115 & 115 & 117 & 113 & 110 & & 102 \\
\hline
\end{tabular}

Source: Norwegian Brewers: http://www.bryggeri-ogdrikkevareforeningen.no 
3.6.2 Consumption of caffeine-containing foods and beverages among Norwegian children and adolescents

Consumption data

The following consumption surveys are used in the exposure assessment from Norway:

- 4-year-old children; UNGKOST 2000 (Pollestad et al. 2002). UNGKOST 2000 is based on a 4-day food consumption registration (185 females and 206 males), where portions should be assigned according to an illustrative book with different food portion sizes.

- 9- and 13-year-old children/adolescents; UNGKOST 2000 (Øverby \& Andersen 2002). UNGKOST 2000 is based on a 4-day food consumption registration, where portions should be assigned according to an illustrative book with different food portion sizes. (9-year-olds: 411 females and 404 males, 13-year-olds: 517 females and 492 males).

The consumption of caffeine-containing foods and drinks among Norwegian children and adolescents is shown in Table N2 (all participants) and Table N3 (consumers only).

Table N2. Consumption of soft drinks, chocolate products, tea and coffee among Norwegian children and adolescents. The numbers include all the children and adolescents in the investigation

\begin{tabular}{|c|c|c|c|c|c|c|c|c|c|}
\hline \multicolumn{10}{|l|}{ All participants } \\
\hline \multirow[t]{2}{*}{ Age } & \multirow{2}{*}{$\begin{array}{l}\text { Type of } \\
\text { drink/food }\end{array}$} & \multirow{2}{*}{$\begin{array}{l}\text { Mean } \\
\text { ml/day }\end{array}$} & \multirow[t]{2}{*}{ SD } & \multicolumn{6}{|c|}{ Percentiles } \\
\hline & & & & 5 & 25 & 50 & 75 & 90 & 95 \\
\hline 4 years & Soft drinks & 59 & 68 & 0 & 0 & 38 & 94 & 150 & 188 \\
\hline \multirow[t]{2}{*}{$(N=391)$} & Soft drinks light & 6 & 22 & 0 & 0 & 0 & 0 & 0 & 38 \\
\hline & Total soft drinks \& soft drinks light & 64 & 70 & 0 & 0 & 38 & 113 & 153 & 200 \\
\hline 9 years & Soft drinks & 166 & 148 & 0 & 58 & 125 & 230 & 363 & 432 \\
\hline \multirow[t]{2}{*}{$(N=815)$} & Soft drinks light & 18 & 65 & 0 & 0 & 0 & 0 & 59 & 125 \\
\hline & Total soft drinks \& soft drinks light & 179 & 157 & 0 & 75 & 144 & 263 & 288 & 467 \\
\hline 13 years & Soft drinks & 288 & 281 & 0 & 113 & 230 & 403 & 595 & 768 \\
\hline \multirow{2}{*}{$(N=1009)$} & Soft drinks light & 30 & 94 & 0 & 0 & 0 & 0 & 113 & 188 \\
\hline & Total soft drinks \& soft drinks light & 318 & 287 & 0 & 125 & 250 & 433 & 643 & 839 \\
\hline $\begin{array}{l}4 \text { years } \\
(\mathrm{N}=391)\end{array}$ & $\begin{array}{l}\text { Chocolate milk } \\
\text { and chocolate products }\end{array}$ & 6 & 8 & 0 & 0 & 3 & 8 & 15 & 23 \\
\hline $\begin{array}{l}9 \text { years } \\
(\mathrm{N}=815)\end{array}$ & $\begin{array}{l}\text { Chocolate milk } \\
\text { and chocolate products }\end{array}$ & 13 & 21 & 0 & 0 & 5 & 18 & 33 & 47 \\
\hline $\begin{array}{l}13 \text { years } \\
(\mathrm{N}=1009)\end{array}$ & $\begin{array}{l}\text { Chocolate milk } \\
\text { and chocolate products }\end{array}$ & 19 & 28 & 0 & 0 & 8 & 26 & 50 & 67 \\
\hline $\begin{array}{l}4 \text { years } \\
(N=391)\end{array}$ & $\begin{array}{l}\text { Brewed tea } \\
\text { and ice tea }\end{array}$ & 4 & 18 & 0 & 0 & 0 & 0 & 0 & 50 \\
\hline $\begin{array}{l}9 \text { years } \\
(\mathrm{N}=815)\end{array}$ & $\begin{array}{l}\text { Brewed tea } \\
\text { and ice tea }\end{array}$ & 9 & 32 & 0 & 0 & 0 & 0 & 25 & 50 \\
\hline $\begin{array}{l}13 \text { years } \\
(\mathrm{N}=1009)\end{array}$ & $\begin{array}{l}\text { Brewed tea } \\
\text { and ice tea }\end{array}$ & 15 & 43 & 0 & 0 & 0 & 0 & 50 & 100 \\
\hline 4 years $(N=391)$ & Coffee* & 1 & 8 & 0 & 0 & 0 & 0 & 0 & 0 \\
\hline 9 years $(\mathrm{N}=815)$ & Coffee* & 1 & 6 & 0 & 0 & 0 & 0 & 0 & 0 \\
\hline 13 years $(\mathrm{N}=1009)$ & Coffee* & 1 & 7 & 0 & 0 & 0 & 0 & 0 & 0 \\
\hline
\end{tabular}

The values for coffee consumption include very few participants. $\mathrm{N}=2$ among 4-year-olds, $\mathrm{N}=6$ among 9-year-olds and $\mathrm{N}=13$ among 13-year-olds. 
Table N3. Consumption of soft drinks, chocolate products, tea and coffee among Norwegian children and adolescents. The numbers include consumers only.

\begin{tabular}{|c|c|c|c|c|c|c|c|c|c|c|}
\hline \multicolumn{11}{|c|}{ Consumers only } \\
\hline \multirow[t]{2}{*}{ Age } & \multirow[t]{2}{*}{ N (\%) } & \multirow{2}{*}{$\begin{array}{l}\text { Type of } \\
\text { drink/food }\end{array}$} & \multirow{2}{*}{$\begin{array}{l}\text { Mean } \\
\text { ml/day }\end{array}$} & \multirow[t]{2}{*}{ SD } & \multicolumn{6}{|c|}{ Percentiles } \\
\hline & & & & & 5 & 25 & 50 & 75 & 90 & 95 \\
\hline \multirow[t]{4}{*}{4 years } & $258(66)$ & Soft drinks & 89 & 66 & 19 & 38 & 75 & 115 & 173 & 225 \\
\hline & $33(8.4)$ & Soft drinks light & 65 & 45 & 19 & 38 & 38 & 75 & 130 & 147 \\
\hline & 272 & Total soft drinks \& soft & & & & & & & & \\
\hline & & drinks light & 92 & 67 & 19 & 38 & 75 & 124 & 187 & 238 \\
\hline \multirow[t]{3}{*}{9 years } & $666(82.2)$ & Soft drinks & 195 & 141 & 38 & 113 & 151 & 263 & 378 & 459 \\
\hline & $122(15.1)$ & Soft drinks light & 122 & 125 & 38 & 58 & 81 & 125 & 230 & 302 \\
\hline & 690 & $\begin{array}{l}\text { Total soft drinks \& soft } \\
\text { drinks light }\end{array}$ & 210 & 150 & 38 & 113 & 170 & 285 & 409 & 488 \\
\hline \multirow[t]{3}{*}{13 years } & $869(87)$ & Soft drinks & 334 & 276 & 58 & 150 & 263 & 438 & 628 & 831 \\
\hline & $160(16)$ & Soft drinks light & 185 & 164 & 38 & 75 & 125 & 246 & 420 & 539 \\
\hline & 906 & $\begin{array}{l}\text { Total soft drinks \& soft } \\
\text { drinks light }\end{array}$ & 353 & 282 & 58 & 163 & 285 & 458 & 677 & 873 \\
\hline 4 years & $234(59.8)$ & $\begin{array}{l}\text { Chocolate milk } \\
\text { and chocolate products }\end{array}$ & 10 & 8 & 2 & 5 & 6 & 13 & 20 & 25 \\
\hline 9 years & $488(60.2)$ & $\begin{array}{l}\text { Chocolate milk } \\
\text { and chocolate products }\end{array}$ & 21 & 23 & 2 & 8 & 15 & 25 & 42 & 54 \\
\hline 13 years & $615(61.2)$ & $\begin{array}{l}\text { Chocolate milk } \\
\text { and chocolate products }\end{array}$ & 30 & 31 & 3 & 12 & 25 & 38 & 60 & 83 \\
\hline 4 years & $28(7.2)$ & $\begin{array}{l}\text { Brewed tea } \\
\text { and ice tea }\end{array}$ & 62 & 33 & 17 & 50 & 50 & 100 & 100 & 100 \\
\hline 9 years & $84(10.4)$ & $\begin{array}{l}\text { Brewed tea } \\
\text { and ice tea }\end{array}$ & 84 & 61 & 25 & 50 & 50 & 100 & 150 & 200 \\
\hline 13 years & $165(16.4)$ & $\begin{array}{l}\text { Brewed tea } \\
\text { and ice tea }\end{array}$ & 91 & 66 & 50 & 50 & 50 & 100 & 150 & 240 \\
\hline 4 years & $2(0.5)$ & Coffee & 94 & 80 & 43 & 86 & 94 & 122 & 139 & 144 \\
\hline 9 years & $6(0.7)$ & Coffee & 62 & 32 & 27 & 50 & 50 & 88 & 100 & 100 \\
\hline 13 years & $13(1.3)$ & Coffee & 55 & 21 & 33 & 50 & 50 & 50 & 90 & 100 \\
\hline
\end{tabular}

4-year-old children; The mean daily consumption of soft drinks in Norway among 4-year-old children was $59 \mathrm{ml}$ based on all participants. The same figures from soft drinks without added sugar were $6 \mathrm{ml} /$ day (Table N2). However, $34 \%$ of the 4-year-olds reported never drinking soft drinks. Among the $66 \%$ in the group of consumers only. the mean consumption of soft drinks was $89 \mathrm{ml} /$ day. The consumption of soft drinks without added sugar was $65 \mathrm{ml} /$ day among the consumers only. Chocolate milk and chocolate products are on the other hand much more frequently consumed in this age group. Sixty percent of the children consumed such products in the survey period and their mean consumption were $10 \mathrm{ml} /$ day (Table N3).

9-year-old children; The mean daily consumption of soft drinks was about three times higher in this age group compared to the 4-year-old children. Approximately $166 \mathrm{ml} /$ day was consumed when including all participants (Table N2). Among the $82 \%$ who were consumers of soft drinks, the consumption was $195 \mathrm{ml} /$ day. Soft drinks without added sugar were consumed by $15 \%$ of the 9 -year-olds and their daily mean consumption were $122 \mathrm{ml}$ (Table N3).

13-year-old children; The mean daily consumption of soft drinks among all participating 13-year-olds was $288 \mathrm{ml}$. This was almost twice 
as much as the consumption among 9-year-olds. Among the $86 \%$ soft drink consumers, the mean daily consumption of regular soft drinks was $334 \mathrm{ml}$. The mean daily consumption of soft drinks without added sugar was $30 \mathrm{ml}$ among all participants and $185 \mathrm{ml}$ among the $16 \%$ in the group of consumers only (Table N2 and N3).

\subsubsection{Exposure to caffeine among Norwegian children and adolescents}

Table N4 shows the intake of caffeine $(\mathrm{mg} /$ day) from different sources among 4-, 9- and 13-year-old Norwegian children and adolescents (all participants). Soft drinks were the most important source for caffeine intake, accounting for $72-81 \%$ of the total caffeine intake in the three age groups. The percentage consumption of chocolate milk and cocoa products was highest in the group of 4-year-old children, accounting for $19 \%$ of the total caffeine intake.

Table N4. Intake of caffeine from different sources (\% of total intake). The numbers include all participants in the dietary surveys

\begin{tabular}{|c|c|c|c|c|c|c|c|}
\hline \multicolumn{8}{|c|}{ All participants } \\
\hline \multirow[t]{3}{*}{ Age } & $\begin{array}{l}\text { Total caffeine } \\
\text { intake }\end{array}$ & $\begin{array}{l}\text { Total caffeine } \\
\text { intake from } \\
\text { soft drinks* }\end{array}$ & $\begin{array}{l}\text { Soft drinks if } \\
\text { all were cola }\end{array}$ & $\begin{array}{l}\text { Soft drinks } \\
\text { light if all } \\
\text { were cola }\end{array}$ & Coffee & Tea & $\begin{array}{l}\text { Chocolate milk } \\
\text { and cocoa- } \\
\text { products }\end{array}$ \\
\hline & Mean (mg/day) & Mean (mg/day) & $\mathrm{mg} / \mathrm{day}$ & mg/day & mg/day & $\mathrm{mg} / \mathrm{day}$ & $\mathrm{mg} / \mathrm{day}$ \\
\hline & & $\begin{array}{l}13 \mathrm{mg} \\
\text { caffeine/dl }\end{array}$ & $\begin{array}{l}13 \mathrm{mg} \\
\text { caffeine/dl }\end{array}$ & $\begin{array}{l}13 \mathrm{mg} \\
\text { caffeine/dl }\end{array}$ & $\begin{array}{l}50 \mathrm{mg} \\
\text { caffeine/dl }\end{array}$ & $\begin{array}{l}16 \mathrm{mg} \\
\text { caffeine/dl }\end{array}$ & $\begin{array}{l}38 \mathrm{mg} \\
\text { caffeine/dl }\end{array}$ \\
\hline 4 years & 11.5 & $8.3(72)$ & $7.6(66)$ & $0.7(6)$ & $0.25(2)$ & $0.7(6)$ & $2.2(19)$ \\
\hline 9 years & 30.4 & $23.3(79)$ & $21.5(71)$ & $2.4(8)$ & $0.25(1)$ & $1.4(5)$ & $4.8(16)$ \\
\hline 13 years & 51.1 & $41.4(81)$ & $37.5(73)$ & $3.8(7)$ & $0.35(1)$ & $2.4(5)$ & $7(14)$ \\
\hline
\end{tabular}

*If all soft drinks were cola drinks

Table N5 shows the mean intake of caffeine (mg/day) from different sources among 4-, 9- and 13-year-old Norwegian children and adolescents (consumers only). The mean intake of caffeine from soft drinks was $12,27.3$ and $45.9 \mathrm{mg} /$ day in 4-, 9- and 13-year-olds respectively. The intake from soft drinks with added sugar was higher than from soft drinks light in all age groups. The mean intake of coffee was relatively high in all three age groups (ranging from $27-47 \mathrm{mg} /$ day), but it should be noted that the number of consumers was very small (Table N3). 
Table N5. Intake of caffeine from different sources. The numbers include consumers only

\begin{tabular}{|c|c|c|c|c|c|c|}
\hline \multicolumn{7}{|c|}{ Consumers only } \\
\hline Age & $\begin{array}{r}\text { Total caffeine } \\
\text { intake from soft } \\
\text { drinks* }\end{array}$ & $\begin{array}{l}\text { Soft drinks if } \\
\text { all were cola }\end{array}$ & $\begin{array}{l}\text { Soft drinks light } \\
\text { if all were cola }\end{array}$ & Coffee & Tea & $\begin{array}{r}\text { Chocolate milk } \\
\text { and cocoa- } \\
\text { products }\end{array}$ \\
\hline & Mean (mg/day) & mg/day & mg/day & mg/day & mg/day & mg/day \\
\hline & $\begin{array}{r}13 \mathrm{mg} \\
\text { caffeine/dl }\end{array}$ & $\begin{array}{r}13 \mathrm{mg} \\
\text { caffeine/dl }\end{array}$ & $\begin{array}{r}13 \mathrm{mg} \\
\text { caffeine/dl }\end{array}$ & $\begin{array}{r}50 \mathrm{mg} \\
\text { caffeine/dl }\end{array}$ & $\begin{array}{r}16 \mathrm{mg} \\
\text { caffeine/dl }\end{array}$ & $\begin{array}{r}38 \mathrm{mg} \\
\text { caffeine/dl }\end{array}$ \\
\hline 4 years & 12 & 11.5 & 8.5 & 47 & 9.9 & 3.7 \\
\hline 9 years & 27.3 & 25.4 & 15.8 & 31 & 13.4 & 8.0 \\
\hline 13 years & 45.9 & 43.4 & 24.1 & 27 & 14.6 & 11.5 \\
\hline
\end{tabular}

*If all soft drinks were cola drinks

\subsubsection{Caffeine exposure per $\mathrm{kg}$ body weight in Norwegian children and} adolescents

The caffeine intake per kg body weight/day in Norwegian 4-, 9-, and 13year-olds, assuming that all soft drinks were cola drinks, is shown in Tables N6, N7 and N8.

Table N6. Intake of caffeine from different sources (per day and per kg body weight/day) in Norwegian 4-year-olds. The numbers include consumers only

\begin{tabular}{|c|c|c|c|c|c|c|c|c|c|c|c|c|}
\hline \multicolumn{13}{|c|}{ Consumers only } \\
\hline & N (\%) & Type of drink/food & Mean & SD & Mean & SD & & & Perce & atiles & & \\
\hline \multirow[t]{3}{*}{ (Mean bw) } & & & mg/ day & & $\begin{array}{l}\mathrm{mg} / \mathrm{kg} \\
\text { bw day }\end{array}$ & & 10 & 25 & 50 & 75 & 90 & 95 \\
\hline & $258(66)$ & Soft drinks* & 11.5 & 8.5 & 0.6 & 0.5 & 0.1 & 0.3 & 0.5 & 0.8 & 1.2 & 1.6 \\
\hline & $33(8.4)$ & $\begin{array}{l}\text { Soft drinks light* } \\
\text { Total soft drinks \& }\end{array}$ & 8.5 & 5.8 & 0.5 & 0.3 & 0.1 & 0.3 & 0.3 & 0.5 & 0.9 & 1.1 \\
\hline \multirow{4}{*}{$\begin{array}{l}4 \text { years } \\
(18 \pm 2.5) \mathrm{kg}\end{array}$} & $272(70)$ & soft drinks light* & 12 & 8.7 & 0.7 & 0.5 & 0.2 & 0.3 & 0.5 & 0.9 & 1.3 & 1.7 \\
\hline & $2(0.5)$ & Coffee & 47 & - & 2.6 & 2.2 & 1.2 & 2.4 & 2.6 & 3.4 & 3.9 & 4.0 \\
\hline & $28(7.2)$ & Tea & 9.9 & - & 0.5 & 0.3 & 0.2 & 0.4 & 0.4 & 0.9 & 0.9 & 0.9 \\
\hline & $234(60)$ & $\begin{array}{l}\text { Chocolate milk and } \\
\text { chocolate products }\end{array}$ & 3.7 & - & 0.2 & 0.2 & 0.0 & 0.1 & 0.1 & 0.3 & 0.4 & 0.5 \\
\hline
\end{tabular}

*The assumption has been made that all soft drinks are cola drinks

Table N6 shows that the mean intake of caffeine from all soft drinks consumed by Norwegian 4-year-olds was $0.7 \mathrm{mg} / \mathrm{kg}$ bw/day, while the intake at the 95 percentile was $1.7 \mathrm{mg} / \mathrm{kg}$ bw/day. The exposure from coffee resulted in high intake levels, but it should be noted that the number of consumers was only 2 . 
Table N7. Intake of caffeine from different sources (per day and per $\mathbf{k g}$ body weight/day) in Norwegian 9-year-olds. The numbers include consumers only

\begin{tabular}{|c|c|c|c|c|c|c|c|c|c|c|c|c|}
\hline \multicolumn{13}{|c|}{ Consumers only } \\
\hline \multirow{2}{*}{$\begin{array}{l}\text { Age } \\
\text { (Mean bw) }\end{array}$} & \multirow[t]{2}{*}{ N (\%) } & \multirow[t]{2}{*}{ Type of drink/food } & \multirow{2}{*}{$\begin{array}{r}\text { Mean } \\
\text { mg/day }\end{array}$} & \multirow[t]{2}{*}{ SD } & \multirow{2}{*}{$\begin{array}{r}\text { Mean } \\
\text { mg/kg } \\
\text { bw day }\end{array}$} & \multirow[t]{2}{*}{ SD } & \multicolumn{6}{|c|}{ Percentiles } \\
\hline & & & & & & & 10 & 25 & 50 & 75 & 90 & 95 \\
\hline \multirow{7}{*}{$\begin{array}{l}9 \text { years } \\
(32 \pm 6.7) \mathrm{kg}\end{array}$} & $666(82.2)$ & Soft drinks* & 25.4 & 18.3 & 0.8 & 0.6 & 0.2 & 0.5 & 0.6 & 1.1 & 1.5 & 1.9 \\
\hline & $122(15.1)$ & Soft drinks light* & 15.8 & 16.3 & 0.5 & 0.5 & 0.2 & 0.2 & 0.3 & 0.5 & 0.9 & 1.2 \\
\hline & $690(85)$ & Total soft drinks \& & & & & & & & & & & \\
\hline & & soft drinks light* & 27.3 & 19.5 & 0.9 & 0.6 & 0.2 & 0.5 & 0.7 & 1.2 & 1.7 & 2.0 \\
\hline & $6(0.7)$ & Coffee & 31 & - & 1.0 & 0.5 & 0.4 & 0.8 & 0.8 & 1.4 & 1.6 & 1.6 \\
\hline & $84(10.4)$ & Tea & 13.4 & - & 0.4 & 0.3 & 0.1 & 0.25 & 0.3 & 0.5 & 0.8 & 1 \\
\hline & $488(60.2)$ & $\begin{array}{l}\text { Chocolate milk and } \\
\text { chocolate products }\end{array}$ & 8.0 & - & 0.3 & 0.3 & 0.0 & 0.1 & 0.2 & 0.3 & 0.5 & 0.6 \\
\hline
\end{tabular}

*The assumption has been made that all soft drinks are cola drinks

Table N7 shows that the mean intake of caffeine from all soft drinks consumed by Norwegian 9 -year-olds was $0.9 \mathrm{mg} / \mathrm{kg}$ bw/day, while the intake at the 95 percentile was $2.0 \mathrm{mg} / \mathrm{kg}$ bw/day.

Table N8 Intake of caffeine from different sources (per day and per kg body weight/day) in Norwegian 13-year-olds. The numbers include consumers only

\begin{tabular}{|c|c|c|c|c|c|c|c|c|c|c|c|c|}
\hline \multicolumn{13}{|l|}{ Consumers only } \\
\hline \multirow{2}{*}{$\begin{array}{l}\text { Age } \\
\text { (Mean bw) }\end{array}$} & \multirow[t]{2}{*}{ N (\%) } & \multirow[t]{2}{*}{ Type of drink/food } & \multirow{2}{*}{$\begin{array}{r}\text { Mean } \\
\text { mg/day }\end{array}$} & \multirow[t]{2}{*}{ SD } & \multirow{2}{*}{$\begin{array}{r}\text { Mean } \\
\mathrm{mg} / \mathrm{kg} \\
\text { bw day }\end{array}$} & \multirow[t]{2}{*}{ SD } & \multicolumn{6}{|c|}{ Percentiles } \\
\hline & & & & & & & 10 & 25 & 50 & 75 & 90 & 95 \\
\hline \multirow{7}{*}{$\begin{array}{l}13 \text { years } \\
(49.4 \pm 9.4) \mathrm{kg}\end{array}$} & 869 (86.5) & Soft drinks* & 43.4 & 35.9 & 0.9 & 0.7 & 0.2 & 0.4 & 0.7 & 1.2 & 1.7 & 2.2 \\
\hline & 169 (15.9) & Soft drinks light* & 24.1 & 21.3 & 0.5 & 0.4 & 0.1 & 0.2 & 0.3 & 0.6 & 1.1 & 1.4 \\
\hline & $906(90)$ & Total soft drinks \& & & & & & & & & & & \\
\hline & & soft drinks light* & 45.9 & 36.6 & 0.9 & 0.7 & 0.3 & 0.4 & 0.8 & 1.2 & 1.8 & 2.3 \\
\hline & $204(20.3)$ & Coffee & 27 & - & 0.6 & 0.2 & 0.3 & 0.5 & 0.5 & 0.5 & 0.9 & 1.0 \\
\hline & 165 (16.4) & Tea & 14.6 & - & 0.3 & 0.2 & 0.2 & 0.2 & 0.2 & 0.3 & 0.5 & 0.8 \\
\hline & $615(61.2)$ & $\begin{array}{l}\text { Chocolate milk and } \\
\text { chocolate products }\end{array}$ & 11.5 & - & 0.2 & 0.2 & 0.0 & 0.1 & 0.2 & 0.3 & 0.5 & 0.6 \\
\hline
\end{tabular}

* The assumption has been made that all soft drinks are cola drinks

Table N8 shows that the mean intake of caffeine from all soft drinks consumed by Norwegian 13-year-olds was $0.9 \mathrm{mg} / \mathrm{kg}$ bw/day, while the intake at the 95 percentile was $2.3 \mathrm{mg} / \mathrm{kg}$ bw/day.

\subsection{Sweden}

\subsubsection{Trends in the consumption of caffeinated beverages}

The Swedish consumption of soft drinks doubled between 1980 and the beginning of this millennium. As Table S1 illustrates, the consumption seems to have gone down in recent years with the sales figures for soft drinks in 2005 being 73 litres per capita. 
Table S1. Sales figures for soft drinks (litres per capita) in Sweden

\begin{tabular}{lrrrrrrrrrr}
\hline Soft drink sales & 1980 & 1985 & 1990 & 1995 & 2000 & 2001 & 2002 & 2003 & 2004 & 2005 \\
\hline Litres/capita/year & 40 & 47 & 63 & 63 & 79 & 81 & 80 & 83 & 76 & 73 \\
\hline
\end{tabular}

Source: Swedish brewery industry: www.sverigesbryggerier.se

Cola beverages comprise $40.6 \%$ of the total marked sales of soft drinks/carbonated beverages, mineral water and cider.

In 2005, $6.2 \mathrm{~kg}$ chocolate per capita was sold in Sweden according to the Association for Food Companies in Sweden (personal communication; Håkan Björklund). A large part of the chocolate sold in Sweden is milk chocolate.

The consumption of coffee in 2005 was $9.15 \mathrm{~kg}$ per capita. Sales figures for coffee are lacking.

\subsubsection{Consumption of caffeine-containing foods and beverages among Swedish children}

Consumption data

A national food survey was carried out during 2003 on 4-year-old children and school children at the age of 8 years (grade 2) and 11 years (grade 5) (Enghardt Barbieri et al. 2006). The method was open, using a food diary covering four consecutive days. All weekdays were evenly represented in the survey. The food diary was filled in by the children or with the help of their parents or caretakers. Portion sizes and amounts of all foods and drinks eaten by the children were estimated with the help of a picture book (Matmallen). It was also noted when and where food was eaten as well as the fat content, mode of preparation, certain additives and brand name. Intake of supplements and level of physical activity was also recorded. In addition, an optically readable questionnaire contained questions about weight, height, parents' education and profession, ethnic background and regional residence.

The 4-year-old children were randomly sampled from a stratified sample of municipalities' representative of Sweden. School children were sampled on the basis of school classes. The sample size of 4-year-old children was 924 of which 590 fulfilled the survey. In grade 2, 1209 children were sampled of which 889 fulfilled the survey and in grade 5, 1290 children were sampled of which 1016 fulfilled the survey.

The 4-year-old children dropped out due to time constraints or that day-care institutions did not want to participate. School children dropped out because it was too difficult, they forgot or did not have time.

A total of 58 food items containing caffeine has been used for the calculation of caffeine intake. 
Table S2. Consumption of cola drinks among Swedish children and adolescents. The numbers include both all the children in the investigation and consumers only.

\begin{tabular}{|c|c|c|c|c|c|c|c|c|c|c|c|c|}
\hline \multicolumn{4}{|c|}{ All participants } & \multicolumn{9}{|c|}{ Cola consumers only } \\
\hline \multirow{2}{*}{$\begin{array}{l}\text { Age } \\
\text { group }\end{array}$} & \multirow[t]{2}{*}{$\mathrm{N}$} & \multirow{2}{*}{$\begin{array}{l}\text { Mean } \\
\text { ml/day }\end{array}$} & \multirow[t]{2}{*}{ SD } & \multirow[t]{2}{*}{ N (\%) } & \multirow{2}{*}{$\begin{array}{l}\text { Mean } \\
\text { ml/day }\end{array}$} & \multirow[t]{2}{*}{ SD } & \multicolumn{6}{|c|}{ Percentiles } \\
\hline & & & & & & & 10 & 25 & 50 & 75 & 90 & 95 \\
\hline 4 years & 590 & 28 & 49 & $213(36)$ & 78 & 52 & 26 & 39 & 65 & 104 & 150 & 190 \\
\hline 8 years & 889 & 50 & 81 & $361(41)$ & 124 & 81 & 51 & 65 & 101 & 156 & 233 & 300 \\
\hline 11 years & 1016 & 68 & 115 & $431(42)$ & 161 & 128 & 52 & 80 & 112 & 204 & 320 & 402 \\
\hline
\end{tabular}

The consumption of cola drinks among Swedish children is shown in Table S2. The mean consumption among all participants in the investigation was highest in the 11-year-old children, which consumed $68 \mathrm{ml}$ cola drinks/day. The corresponding value for consumers only was $161 \mathrm{ml} /$ day. From the table it can be seen that only $36 \%$ of the 4 -year-olds, $41 \%$ of the 8 -year-olds and $42 \%$ of the 11 -year-olds drink cola drinks.

Table S3. Consumption of cola drinks, chocolate milk, tea and coffee among Swedish children. The numbers include all the children and adolescents in the investigation.

\begin{tabular}{|c|c|c|c|c|c|c|c|c|c|}
\hline \multicolumn{10}{|c|}{ All participants } \\
\hline \multirow[t]{2}{*}{ Age } & \multirow{2}{*}{$\begin{array}{l}\text { Type of } \\
\text { drink/food }\end{array}$} & \multirow{2}{*}{$\begin{array}{l}\text { Mean } \\
\text { ml/day }\end{array}$} & \multirow[t]{2}{*}{ SD } & \multirow{2}{*}{$\begin{array}{c}\text { Percentiles } \\
10\end{array}$} & \multirow{2}{*}{25} & \multirow[b]{2}{*}{50} & \multirow[b]{2}{*}{75} & \multirow[b]{2}{*}{90} & \multirow[b]{2}{*}{95} \\
\hline & & & & & & & & & \\
\hline \multirow[t]{2}{*}{4 years } & Cola drinks & 25 & 46 & & & & 39 & 86 & 125 \\
\hline & Cola drinks light & 3 & 17 & & & & & & \\
\hline \multirow[t]{2}{*}{8 years } & Cola drinks & 44 & 76 & & & & 78 & 150 & 200 \\
\hline & Cola drinks light & 6 & 27 & & & & & & 51 \\
\hline \multirow[t]{2}{*}{11 years } & Cola drinks & 63 & 112 & & & & 91 & 200 & 286 \\
\hline & Cola drinks light & 6 & 30 & & & & & & 16 \\
\hline \multirow[t]{2}{*}{4 years } & Chocolate milk and & 36 & 72 & & & & 50 & 113 & 183 \\
\hline & other chocolate products & 14 & & & & & & & \\
\hline \multirow[t]{2}{*}{8 years } & Chocolate milk and & 46 & 80 & & & & 53 & 150 & 204 \\
\hline & other chocolate products & 17 & & & & & & & \\
\hline \multirow[t]{2}{*}{11 years } & Chocolate milk and & 50 & 90 & & & & 63 & 196 & 239 \\
\hline & other chocolate products & 17 & & & & & & & \\
\hline 4 years & $\begin{array}{l}\text { Brewed tea } \\
\text { and ice tea }\end{array}$ & 3 & 16 & & & & & & \\
\hline 8 years & $\begin{array}{l}\text { Brewed tea } \\
\text { and ice tea }\end{array}$ & 9 & 37 & & & & & & 50 \\
\hline 11 years & $\begin{array}{l}\text { Brewed tea } \\
\text { and ice tea }\end{array}$ & 17 & 50 & & & & & 50 & 113 \\
\hline 4 years & Coffee* & 0 & 3 & & & & & & \\
\hline 8 years & Coffee* & 1 & 12 & & & & & & \\
\hline 11 years & Coffee* & 1 & 12 & & & & & & \\
\hline
\end{tabular}

${ }^{*} \mathrm{~N}=10$ among 4-year-olds. ${ }^{*} \mathrm{~N}=7$ among 8-year-olds. ${ }^{*} \mathrm{~N}=20$ among 11 -year-olds

The mean consumption of cola drinks (cola + cola light) amounted to 28 $\mathrm{ml} /$ day for the 4-year-olds, $50 \mathrm{ml}$ for the 8 -year-olds and $69 \mathrm{ml}$ for the 11-year-old children. Approximately $10 \%$ of the cola drinks were light drinks. At the $95^{\text {th }}$ percentile, the youngest children consumed $125 \mathrm{ml}$ and the oldest consumed approximately $300 \mathrm{ml} /$ day (Table S3).

Consumption of the following cocoa-containing foods was reported in the survey: milk chocolate candy, pure milk chocolate (bars), cocoa with sugar, chocolate milk, chocolate sponge cakes (e.g. chocolate brownies, 
chocolate cakes, chocolate biscuits etc), chocolate desserts (e.g. chocolate puddings etc), chocolate ice cream and dark chocolate (bars). Of these categories chocolate milk was the cocoa-containing food consumed by all three age groups in the largest amounts. The mean consumption of chocolate milk ranged from $36-50 \mathrm{ml} /$ day in the three age groups. Standard deviations for the intake of chocolate milk were large and in the range of $72-90 \mathrm{ml} /$ day. At the $95^{\text {th }}$ percentile, the consumption of chocolate milk ranged from 183 (4-year-olds) to 239 (11-year-olds) ml/day. The consumption of other types of cocoa-containing foods was considerably smaller. Generally the amounts reported for these types were a few grams per day. Dark chocolate was practically not consumed at all by any of the age groups (Table S3).

The mean consumption of tea in the whole survey ranged from 3 $\mathrm{ml} /$ day to $17 \mathrm{ml} /$ day. At the $95^{\text {th }}$ percentile, the consumption of tea ranged from $50 \mathrm{ml} /$ day (8-year-olds) to $113 \mathrm{ml} /$ day (11-year-olds).

Very few children in the survey reported consumption of coffee. Even in the group of children of grade 5 (11-year-olds) only 20 of 1016 children reported consumption of coffee. Thus the mean consumption of coffee in the whole survey was very limited; ranging from $0 \mathrm{ml} /$ day to 1 $\mathrm{ml} /$ day (Table S3). When consumption of coffee by "consumers only" was considered the daily consumption ranged from 22 to $81 \mathrm{ml}$. The highest average consumption $(81 \mathrm{ml} /$ day) was reported by the children of grade 2 (8-year-olds).

\subsubsection{Exposure to caffeine among Swedish children}

Table S4 shows the mean intake of caffeine (mg/day) among 4-, 8- and 11-year-old Swedish children (all participants).

Table S4. Intake of caffeine from different sources (\% of total intake). The numbers include all participants

\begin{tabular}{|c|c|c|c|c|c|c|c|c|}
\hline \multicolumn{9}{|c|}{ All participants } \\
\hline \multirow[t]{3}{*}{ Age } & $\begin{array}{l}\text { Total caf- } \\
\text { feine intake }\end{array}$ & $\begin{array}{r}\text { Cola drinks } \\
\text { (Cola and } \\
\text { cola light) }\end{array}$ & Coffee & Tea & $\begin{array}{r}\text { Chocolate milk } \\
\text { and cocoa with } \\
\text { sugar }\end{array}$ & $\begin{array}{r}\text { Chocolate candy } \\
\text { All types of } \\
\text { chocolate candy }\end{array}$ & $\begin{array}{r}\text { Chocolate } \\
\text { cakes }\end{array}$ & $\begin{array}{r}\text { Chocolate dessert } \\
\text { (also including } \\
\text { icecream) }\end{array}$ \\
\hline & $\begin{array}{l}\text { Mean }(\mathrm{mg} / \\
\text { day) }\end{array}$ & $\mathrm{mg} / \mathrm{day}$ & $\mathrm{mg} / \mathrm{day}$ & mg/day & mg/day & mg/day & mg/day & mg/day \\
\hline & & $\begin{array}{r}13 \mathrm{mg} \\
\text { caffeine/dl }\end{array}$ & $\begin{array}{r}69 \mathrm{mg} \\
\text { caffeine/dl }\end{array}$ & $\begin{array}{r}24 \mathrm{mg} \\
\text { caffeine/dl }\end{array}$ & $\begin{array}{r}1.5 \mathrm{mg} \\
\text { caffeine/dl }\end{array}$ & $\begin{array}{r}2.3 \mathrm{mg} \\
\text { caffeine/dl }\end{array}$ & $\begin{array}{r}20 \mathrm{mg} \\
\text { caffeine/dl }\end{array}$ & $\begin{array}{r}14.6 \mathrm{mg} \\
\text { caffeine/dl }\end{array}$ \\
\hline 4 years & 7.15 & $3.7(52)$ & $0.2(3)$ & $0.7(10)$ & $0.6(8)$ & $0.5(7)$ & $0.8(11)$ & $0.7(9)$ \\
\hline 8 years & 12.26 & $6.6(54)$ & $0.4(4)$ & $2.2(18)$ & $0.7(6)$ & $0.8(7)$ & $0.9(7)$ & $0.6(5)$ \\
\hline 11 years & 16.82 & $8.9(53)$ & $0.7(4)$ & $4.1(24)$ & $0.8(5)$ & $1.0(6)$ & $0.8(5)$ & $0.5(3)$ \\
\hline
\end{tabular}

In the average consumer, only slightly more than half of the caffeine intake came from cola drinks. Cocoa-containing products represented the second largest contributor to caffeine, accounting for $19-35 \%$ of the total caffeine intake. The youngest children (4-year-olds) had the largest con- 
sumption of cocoa-containing products. Tea consumption was also an important contributor to the total caffeine intake. Among the 11-year-old children tea contributed to $24 \%$ of the total intake (Table S4).

Table S5 shows the mean intake of caffeine ( $\mathrm{mg} /$ day) and percentiles from cola drinks among 4-, 8- and 11-year-old Swedish children (consumers only). The mean intake of caffeine ranged from $10.1 \mathrm{mg} /$ day in 4-yearold-children to $20.9 \mathrm{mg} /$ day in the 11 year-olds. The intake at the 95 percentile was $24.7 \mathrm{mg} /$ day, $39 \mathrm{mg} /$ day and $52.3 \mathrm{mg} /$ day for the 4-year-olds, 8 -year-olds and 11-year-olds, respectively.

Table S5. Intake of caffeine from cola drinks. The numbers include consumers only

\begin{tabular}{|c|c|c|c|c|c|c|c|c|c|c|}
\hline \multicolumn{11}{|c|}{ Consumers only } \\
\hline \multirow[t]{2}{*}{ Age } & \multirow[t]{2}{*}{ N (\%) } & \multirow{2}{*}{$\frac{\text { Caffeine }}{\mathrm{mg} / \mathrm{dl}}$} & \multirow{2}{*}{$\begin{array}{r}\text { Mean } \\
\text { (mg/day) }\end{array}$} & \multirow[t]{2}{*}{ SD } & \multicolumn{6}{|c|}{ Percentiles } \\
\hline & & & & & 10 & 25 & 50 & 75 & 90 & 95 \\
\hline 4 years & $213(36)$ & 13 & 10.1 & 6.8 & 3.4 & 5.1 & 8.5 & 13.5 & 19.5 & 24.7 \\
\hline 8 years & 361 (41) & 13 & 16.1 & 10.5 & 6.6 & 8.5 & 13.1 & 20.3 & 30.3 & 39.0 \\
\hline 11 years & 431 (42) & 13 & 20.9 & 16.6 & 6.8 & 10.4 & 14.6 & 26.5 & 41.6 & 52.3 \\
\hline
\end{tabular}

The total mean intake and distribution of caffeine for the $90^{\text {th }}$ percentile of Swedish children 4-, 8- and 11-year-old are presented in Table S6.

Table S6. Total caffeine intake from all sources among the $90^{\text {th }}$ percentile of participants. Percentage of the total caffeine intake (\%).

\begin{tabular}{|c|c|c|c|c|c|c|c|c|c|}
\hline Age & $\begin{array}{l}\text { Total mean caffeine } \\
\text { intake ( } 90 \text { percen- } \\
\text { tile) ( } \mathrm{mg} / \mathrm{day})\end{array}$ & $\begin{array}{l}\text { Cola drinks } \\
\text { (Cola and } \\
\text { cola light) }\end{array}$ & $\begin{array}{r}\text { Energy } \\
\text { drinks }\end{array}$ & Coffee & Tea & $\begin{array}{r}\text { Chocolate milk } \\
\text { and cocoa with } \\
\text { sugar }\end{array}$ & $\begin{array}{r}\text { Chocolate candy } \\
\text { All types of } \\
\text { chocolate candy }\end{array}$ & $\begin{array}{r}\text { Chocolate } \\
\text { cakes }\end{array}$ & $\begin{array}{r}\text { Chocolate dessert } \\
\text { (also including } \\
\text { icecream) }\end{array}$ \\
\hline 4 years & 18.1 & $11.2(62)$ & 0 & 0 & 0 & $1.8(10)$ & $1.4(8)$ & $2.9(16)$ & $1.6(9)$ \\
\hline 8 years & 30.6 & $19.5(64)$ & 0 & 0 & 0 & $2.4(12)$ & $2.8(9)$ & 3.3 (11) & $0.6(2)$ \\
\hline 11 years & 43.9 & $26(59)$ & 0 & 0 & $12(27)$ & $3.1(7)$ & $3.2(7)$ & $2.9(7)$ & 0 \\
\hline
\end{tabular}

More than half of the caffeine intake came from cola drinks in the group of consumers of the $90^{\text {th }}$ percentile. Tea consumption was an important contributor with $27 \%$ to the total caffeine intake among 11 -year-old children. Different cocoa products contributed to the total caffeine intake with $0-16 \%$. The total contribution by cocoa products was considerable, especially among the youngest children. The children who had the highest caffeine intake reached $100-250 \mathrm{mg}$ /day by drinking coffee and tea. 
3.7.4 Caffeine exposure per $\mathrm{kg}$ body weight in Swedish children

Table S7. Total caffeine intake of caffeine (per day and per kg body weight/day) in Swedish children and adolescents. The numbers include all participants

\begin{tabular}{|c|c|c|c|c|c|c|c|c|c|c|}
\hline \multicolumn{11}{|l|}{ All participants } \\
\hline \multirow{2}{*}{$\begin{array}{l}\text { Age } \\
\text { (Mean bw) }\end{array}$} & \multirow{2}{*}{$\begin{array}{r}\text { Mean } \\
\text { mg/day }\end{array}$} & \multirow[t]{2}{*}{ SD } & \multirow{2}{*}{$\begin{array}{r}\text { Mean } \\
\text { mg/kg } \\
\text { bw/day }\end{array}$} & \multirow[t]{2}{*}{ SD } & \multicolumn{6}{|c|}{ Percentiles } \\
\hline & & & & & 10 & 25 & 50 & 75 & 90 & 95 \\
\hline 4 years $(18 \mathrm{~kg})$ & 7.1 & 8.8 & 0.4 & 0.5 & 0 & 0.1 & 0.2 & 0.6 & 1 & 1.3 \\
\hline 8 years $(32 \mathrm{~kg})$ & 12.3 & 16.6 & 0.4 & 0.5 & 0 & 0 & 0.2 & 0.5 & 1 & 1.4 \\
\hline 11 years $(42 \mathrm{~kg})$ & 16.8 & 21.5 & 0.4 & 0.5 & 0 & 0 & 0.2 & 0.6 & 1 & 1.4 \\
\hline
\end{tabular}

The children in all age groups had approximately the same intake of caffeine per $\mathrm{kg}$ body weight $(0.4 \mathrm{mg} / \mathrm{kg}$ bw/day among all participants and 0.5-0.6 among consumers only) (Table S7 and Table S8). The intake of caffeine at the $90^{\text {th }}$ percentile was 2.5 times the mean intake in all age groups, reaching approximately $1 \mathrm{mg} / \mathrm{kg}$ body weight.

Table S8. Intake of caffeine from cola drinks (per day and per kg body weight/day) in Swedish children and adolescents. The numbers include consumers only

\begin{tabular}{|c|c|c|c|c|c|c|c|c|c|c|c|}
\hline Consumers only & & & & & & & & & & & \\
\hline \multirow[t]{2}{*}{ Age (mean bw) } & \multirow[t]{2}{*}{ N (\%) } & \multirow{2}{*}{$\begin{array}{r}\text { Mean } \\
\text { mg/day }\end{array}$} & \multirow[t]{2}{*}{ SD } & \multirow{2}{*}{$\begin{array}{r}\text { Mean } \\
\mathrm{mg} / \mathrm{kg} \\
\text { bw/day }\end{array}$} & \multirow[t]{2}{*}{ SD } & \multicolumn{6}{|c|}{ Percentiles } \\
\hline & & & & & & 10 & 25 & 50 & 75 & 90 & 95 \\
\hline 4 years $(18 \mathrm{~kg})$ & $213(36)$ & 10.1 & 6.8 & 0.6 & 0.4 & 0.2 & 0.3 & 0.5 & 0.8 & 1.1 & 1.4 \\
\hline 8 years $(31.5 \mathrm{~kg})$ & $361(41)$ & 16.1 & 10.5 & 0.5 & 0.3 & 0.2 & 0.3 & 0.4 & 0.6 & 1.0 & 1.2 \\
\hline 11 years (42 kg) & $431(42)$ & 20.9 & 16.6 & 0.5 & 0.4 & 0.2 & 0.2 & 0.3 & 0.6 & 1.0 & 1.2 \\
\hline
\end{tabular}




\subsection{Summary of consumption data in the Nordic countries}

3.8.1 Overall trends, soft drink sales in the Nordic countries.

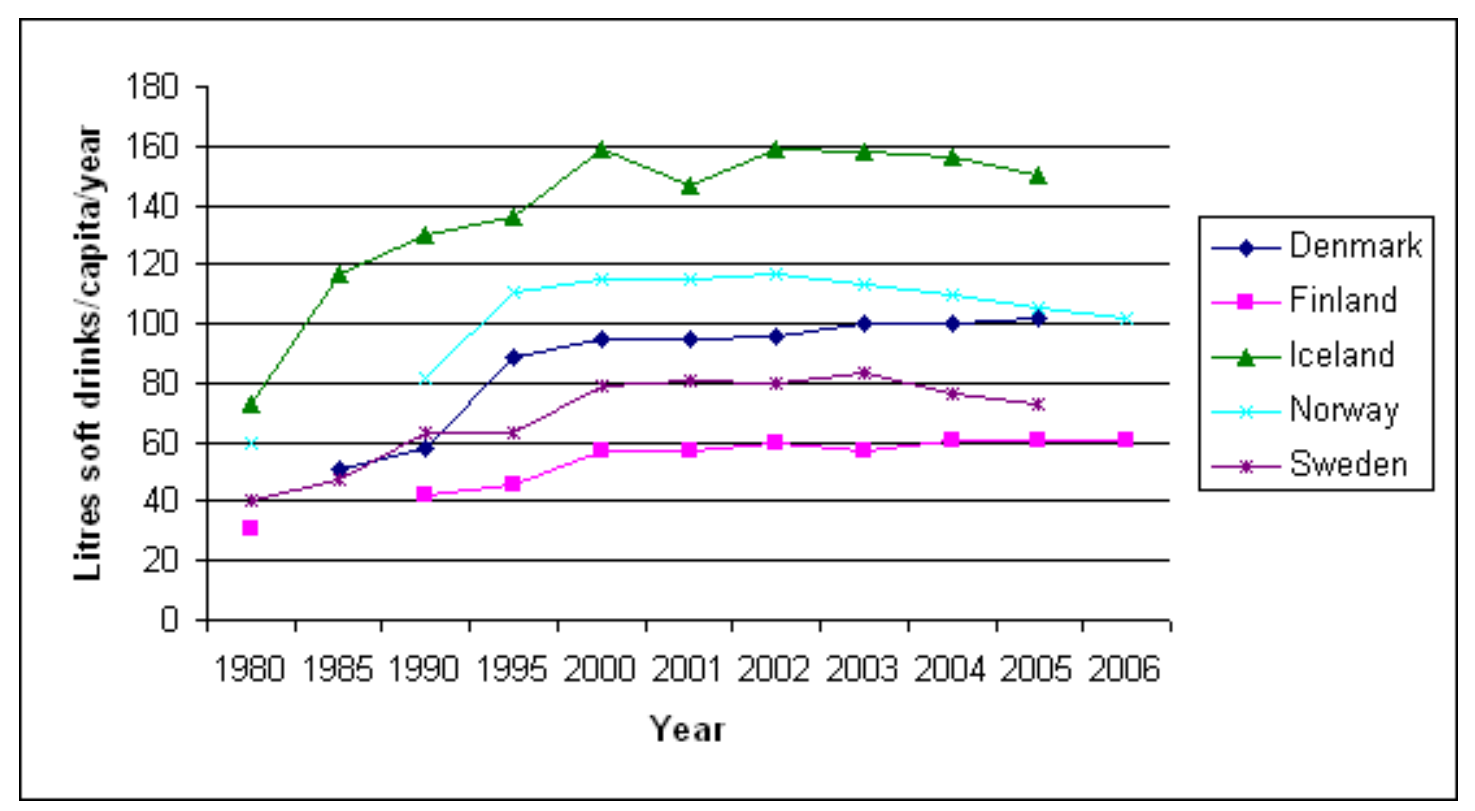

Figure 5. Overall consumption of carbonated soft drinks (litres/capita/year) in the Nordic countries, en gros figures.

Figure 5 shows that among the Nordic countries, Iceland, overall, has had the highest sales figures for soft drinks the last two decades, while the Finns buy least. The figure also shows that sales seem to have stabilized, or are on a decline, in all countries the last 5 years. We have no data to tell if the decline affects all age groups similarly or if it is first and foremost certain sub-groups, like young people, who consume less than earlier. 


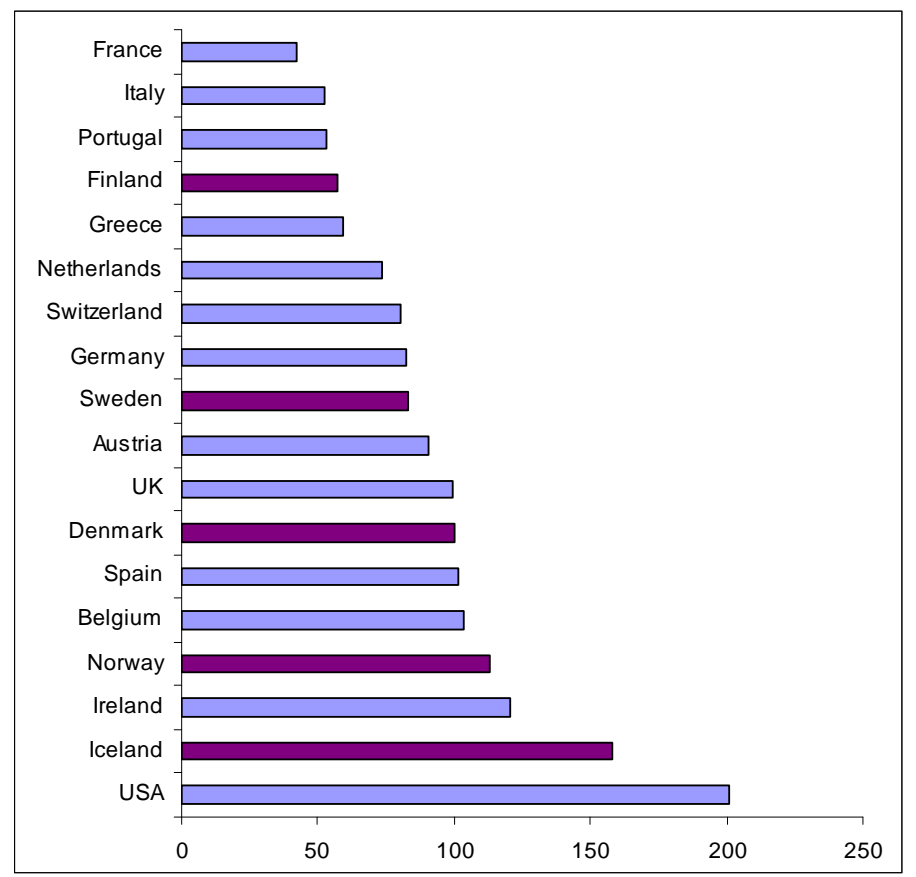

Figure 6. Overall consumption of carbonated soft drinks (litres/capita/year) in the Nordic countries compared to other Western countries (Modified from www.brom.no). The figures for the Nordic countries are data from 2003, while it is unclear which year the figures for the other countries are based on.

Figure 6 shows that only the Mediterranean countries are in the same range of low sales levels of soft drinks as Finland. The high Icelandic consumption seems to be intermediate between average European levels and USA levels.

\subsubsection{Soft drink consumption among children and adolescents}

The caffeine intake data in children and adolescents vary in quality between the five Nordic countries. All countries have excellent dietary surveys covering one or more relevant age groups, but the Danish and Norwegian studies have had focus on the total soft drink consumption rather than caffeine consumption. Accordingly, this report has had to make assumptions about the Danish and Norwegian data on the real intake of caffeine provided when only soft drink consumption data have been available.

The investigations also vary with respect to the age groups studied. This should be kept in mind when studying the figures in this chapter, especially the oldest age group, where the differences are rather large. The oldest group among the Swedish children was 11-year-olds, while Iceland had excellent caffeine data on 17-year-olds. The ages were more similar among the youngest; here all the Nordic countries apart from Finland had current data on 4- or 6-year-olds. Data from the Finnish lon- 
gitudinal STRIP-study on 4- and 6-year-olds are from years 1994-1998 and were, therefore, not used.

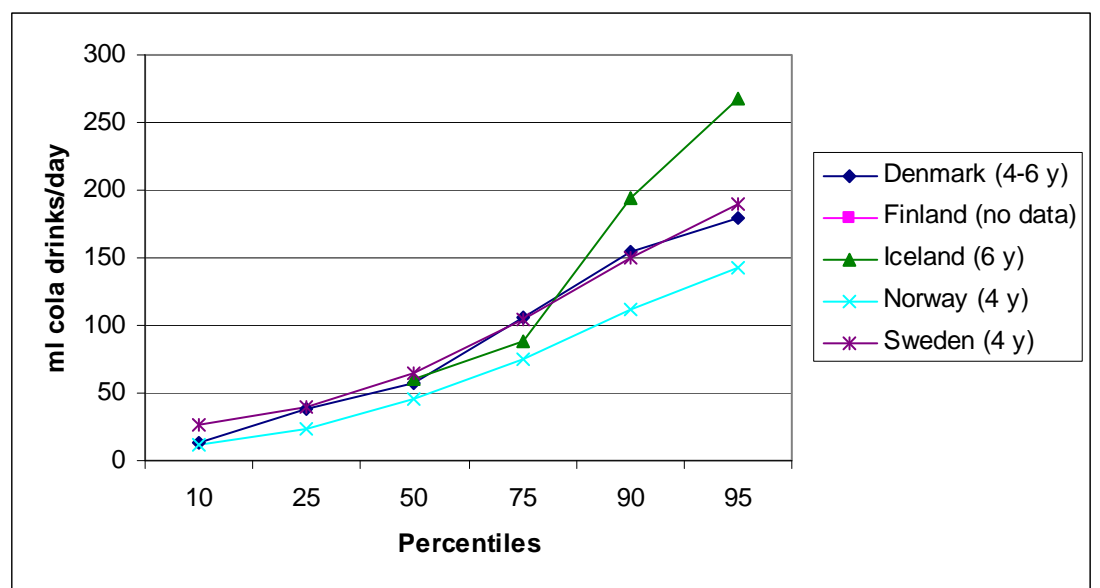

Figure 7. Cola drink consumption in 4- to 6-year-olds in the Nordic countries ( consumers only). The Icelandic and Swedish data are based on actual consumption, while the Danish and Norwegian data are based on the assumption that cola drinks comprise 60\% of the total soft drink consumption. Finland did not have relevant data in this age group.

Figure 7 shows that among the youngest age groups, cola drink consumption in the Nordic countries is fairly similar until one reaches the 75percentile. Among the $25 \%$ of the highest consumers, Icelandic children consume most and Norwegian children least. Based on total sales data, it is reasonable to assume that if Finnish data had existed, Finnish children in this age group would have consumed least of all.

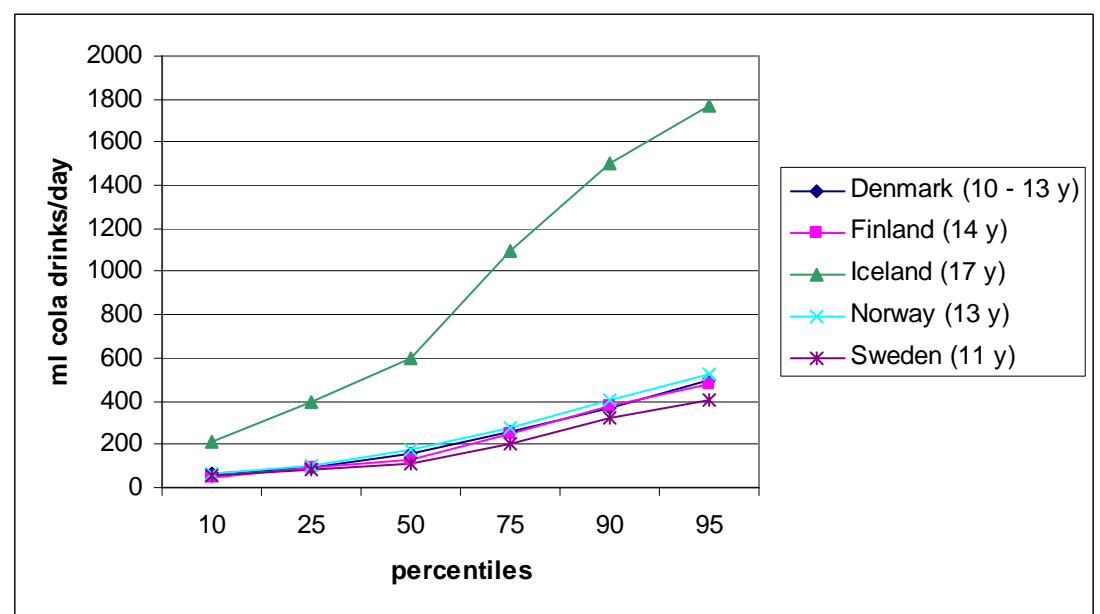

Figure 8. Cola drink consumption in 11- to 17-year-olds in the Nordic countries (consumers only). The Finnish, Icelandic and Swedish data are based on actual consumption, while the Danish and Norwegian data are based on the assumption that cola drinks comprise $60 \%$ of the total soft drink consumption.

The striking and high consumption of cola drinks among Icelandic teenagers (Figure 8) must be interpreted with some caution: the teenagers 
included in the Icelandic survey are 3 to 6 years older than the participants from the other Nordic countries. On the other hand, the Danish consumption data (see chapter 3.3.2) show that after the age of 12, average soft drink consumption levels stabilize or might even decline. If this applies to the other Nordic countries too, then the data might be more comparable than at first glance.

\subsubsection{Caffeine exposure among children and adolescents in the Nordic countries}

The exposure to caffeine from cola drinks among children and adolescents in the Nordic countries is presented in Figure 9 and 10. As for the consumption data shown in Figure 7 and 8, the assumption that cola drinks comprise $60 \%$ of the total soft drink consumption in Denmark and Norway has been made when calculating the caffeine exposure in $\mathrm{mg} /$ day.

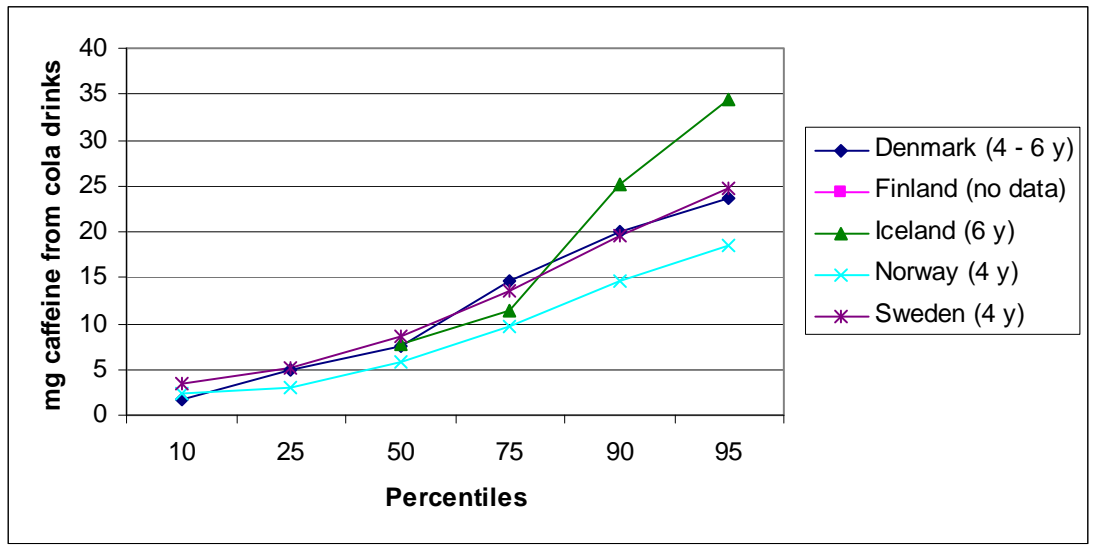

Figure 9. Caffeine exposure (mg/day) from cola drinks in 4- to 6-year-olds in the Nordic countries (consumers only). The figure is based on the assumption that $60 \%$ of soft drink consumption in Denmark and Norway is cola drinks. The data from Iceland and Sweden are based on actual consumption data. Finland did not have relevant data in this age group.

Figure 9 mirrors the consumption data presented in Figure 7, showing that Icelandic children have the highest intake of caffeine among the Nordic countries. The intake of caffeine in Danish and Swedish children follows a similar pattern for the different percentiles, while Norwegian children have the lowest exposure to caffeine among the youngest age groups. Finland did not have relevant data for this age group. 


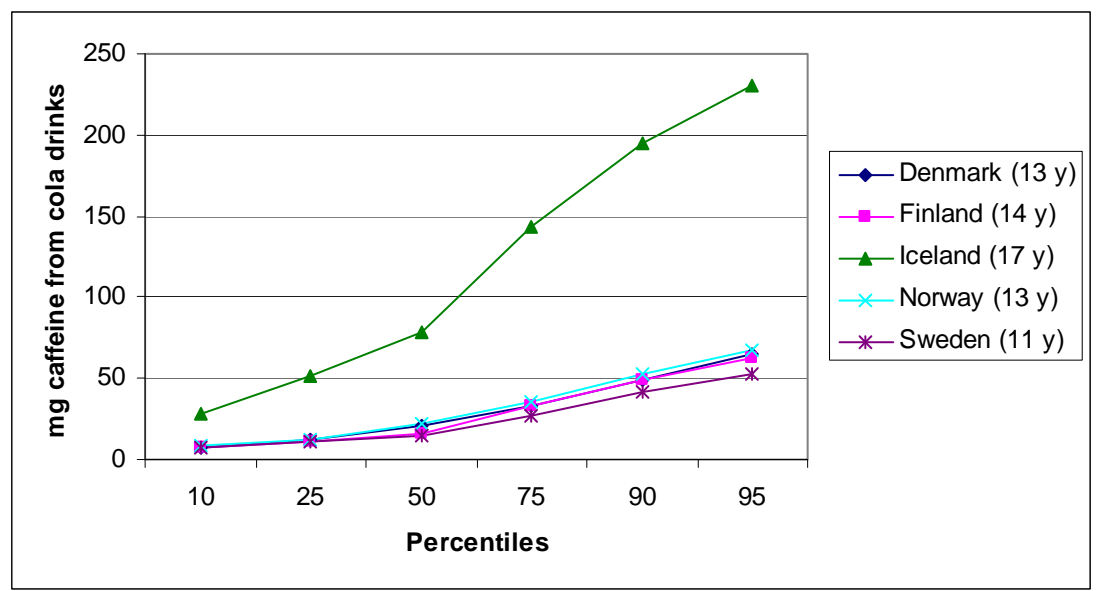

Figure 10. Caffeine exposure (mg/day) from cola drinks in 11- to 17-year-olds in the Nordic countries (consumers only). The figure is based on the assumption that $60 \%$ of soft drink consumption in Denmark and Norway is cola drinks. The data from Finland, Iceland and Sweden are based on actual consumption data.

Figure 10 mirrors the data from Figure 8, showing that Icelandic teenagers have the highest exposure to caffeine of the Nordic countries. The curves are not directly comparable because the Icelandic youngsters are so much older than the participants from the other Nordic countries. It should be noted that the data only includes estimated caffeine exposure from soft drinks. The Danish data indicate (see chapter 3.3.2) that after the age of 15 , coffee consumption increases steadily in teenagers. Thus the exposure from other caffeine-containing foods and beverages comes in addition to the levels shown in Figure 10, and especially after mid adolescence our estimations of exposure to caffeine are too low in the higher percentiles.

\subsubsection{Caffeine exposure from cola drinks per $\mathrm{kg}$ body weight among children and adolescents in the Nordic countries}

The exposure to caffeine from cola drinks per kg body weight per day among children and adolescents in the Nordic countries is presented in Figure 11 and 12. The assumption that cola drinks comprise $60 \%$ of the total soft drink consumption has been made for the Danish and Norwegian data. 


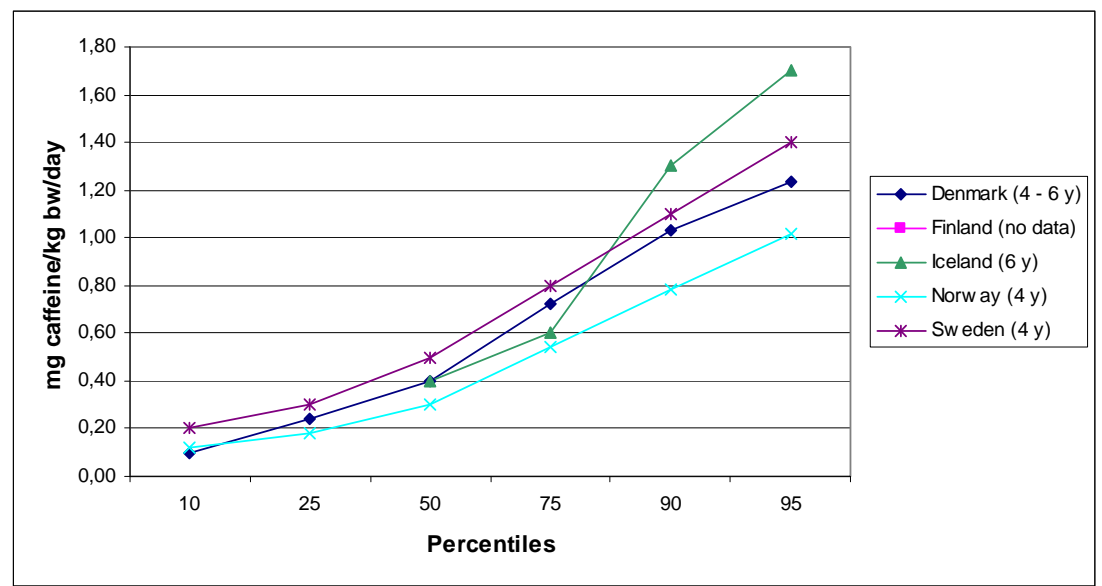

Figure 11. Caffeine exposure ( $\mathrm{mg} / \mathrm{kg}$ bw/day) from cola drinks in 4- to 6-year-olds in the Nordic countries (consumers only). The Icelandic and Swedish intake estimations are based on actual consumption data, while the Danish and Norwegian intake estimations are based on the assumption that cola drinks comprise 60\% of the total soft drink consumption. Finland did not have relevant data in this age group.

Figure 11 shows that the exposure to caffeine per kg body weight per day seems to be more or less similar in the Nordic countries below the $75^{\text {th }}$ percentile among the age groups 4 to 6 years, although Swedish children seem to have the highest and Norwegian children the lowest exposure levels. Amongst the high-consumers, the 5 percent of Icelandic children who consume most are exposed to $1.6 \mathrm{mg}$ per $\mathrm{kg}$ body weight per day or more, while Swedish, Danish and Norwegian children follow after, but at a more moderate pace. It is important to be aware that the true expose to caffeine is probably higher in all percentiles above the $50^{\text {th }}$, as many children also get a fair amount of caffeine from chocolate drinks, see Tables D2, N3 and S3. Finland did not have relevant data for this age group.

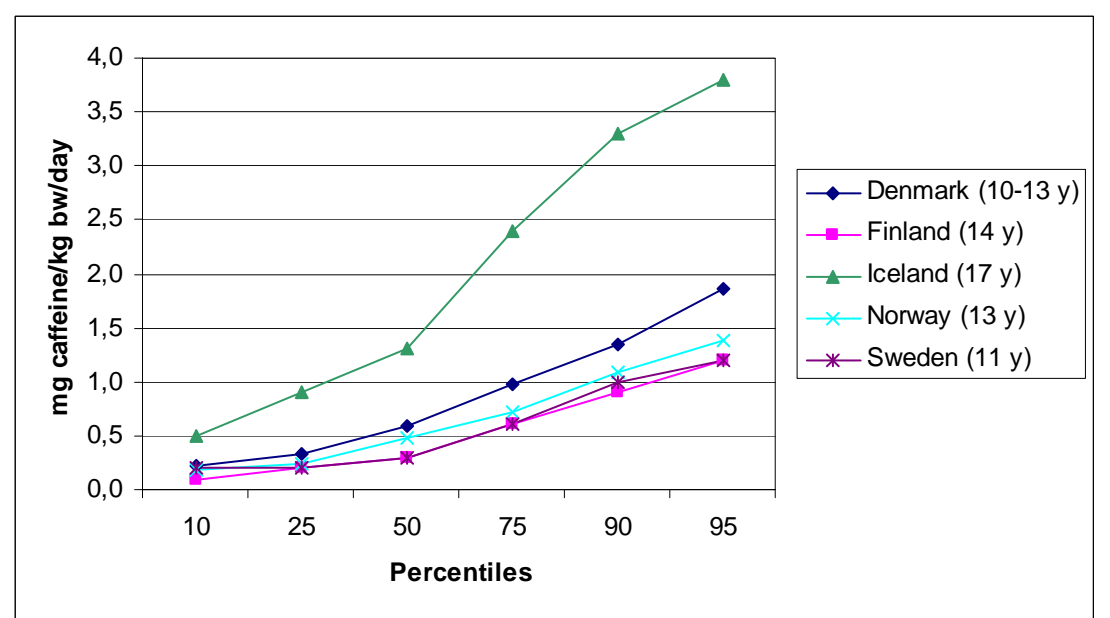

Figure 12. Caffeine exposure ( $\mathrm{mg} / \mathrm{kg}$ bw/day) from cola drinks in 11- to 17-year-olds in the Nordic countries (consumers only). The Finnish, Icelandic and Swedish intake estimations are based on actual consumption data, while the Danish and Norwegian intake estimations are based on the assumption that cola drinks comprise $60 \%$ of the total soft drink consumption. 
Figure 12 mirrors the data from Figure 8 and 10 showing that Icelandic teenagers have the highest exposure to caffeine of the Nordic countries. The curves are not directly comparable because the Icelandic youngsters are so much older than than the participants from the other Nordic countries. Also here one has to be aware that the data only include estimated caffeine exposure from soft drinks. The Danish data indicate (see chapter 3.3.2) that after the age of 15 , coffee consumption increases steadily in teenagers. Thus the exposure from other caffeine-containing foods and beverages comes in addition to the levels shown in Figure 12, and especially after mid adolescence our estimations of true exposure to caffeine are probably too low in the higher percentiles.

Apart from the Finnish data, all the consumption data are 4-5 years old. Thus we do not know if the stabilization or slight decline in per capita sales figures for soft drinks also would affect the consumption data if we conducted a dietary survey among adolescents today. Furthermore, an eventual decline in soft drink consumption might be compensated for by an increase in consumption of e.g. coffee and tea among teenagers, so as a starting point for the risk characterisation, we believe the estimations presented in Figure 12 are reasonably good. 



\section{Risk characterisation of caffeine intake among children and adolescents}

There has been an increase in caffeine exposure among children and adolescents the last 2-3 decades, mainly due to an increased consumption of cola drinks. The increase in consumption can partly be explained by easier availability; even schools now have cola vending machines. However, the last 7 years, the overall sales of soft drinks have stabilised or are on a decline in the Nordic countries. There are no data to reveal if this decline also encompasses the cola drink consumption among children and adolescents. It has become a fashion to drink bottled water, but in youngsters, we do not know if this is a substitution for soft drinks or tap water.

\section{Exposure estimations}

We have seen that there are somewhat different consumption patterns in the Nordic countries.

It is important to be aware that the summary figures in chapter 3.8 only include cola drinks. The real exposure to caffeine for all countries is probably $40-100 \%$ higher if caffeine from chocolate containing foods and drinks, tea and coffee is included. This applies especially to teenagers, where the percentage of coffee-and tea-consumers steadily increases. Table D6 indicates that the younger the age group, the larger the percentage of caffeine comes from cola drinks. In the adolescent group, we have based our assumptions on the Danish Brewers Association data showing that approximately $60 \%$ of the total consumption of soft drinks is cola drinks.

In Figure 13 and 14, the NOEL and LO(A)ELs for the different endpoints described in chapter 2.5.9 has been included as vertical lines to indicate the relationship between the estimated caffeine exposure per $\mathrm{kg}$ body weight per day in Nordic childen and adolescents and these threshold values. 


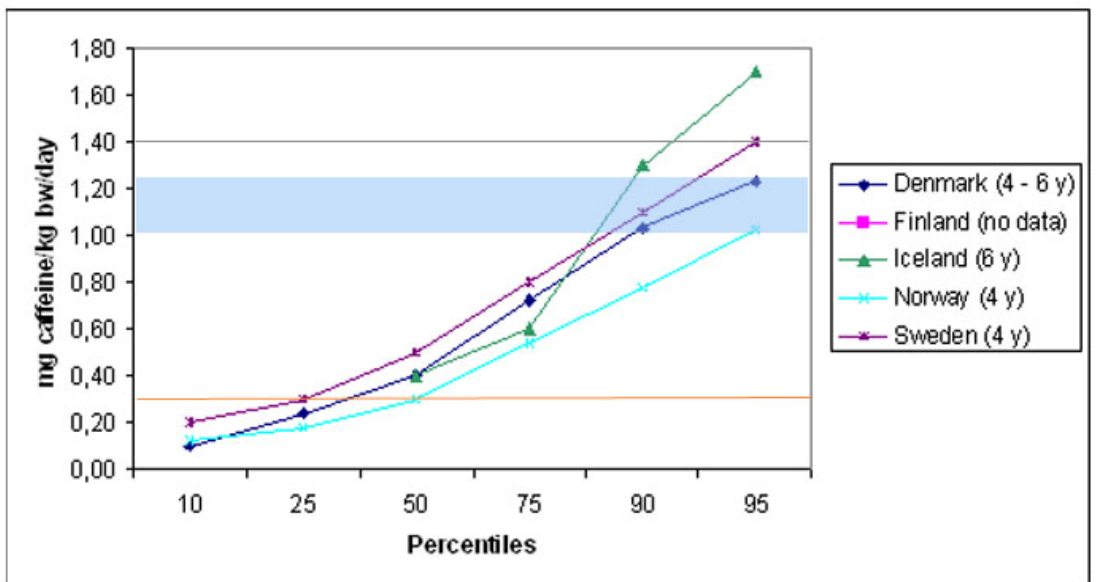

Figure 13. Caffeine exposure ( $\mathrm{mg} / \mathrm{kg}$ bw/day) from cola drinks in 4- to 6-year-olds in the Nordic countries (consumers only) compared with the threshold values suggested in the hazard characterisation (chapter 2.5.9). The (blue) area between 1 and $1.25 \mathrm{mg} / \mathrm{kg} \mathrm{bw}$ indicates the range where effects, i.e. withdrawal symptoms, can be observed. The (orange) line at $0.3 \mathrm{mg} / \mathrm{kg} \mathrm{bw}$ indicates the NOEL. At $1.4 \mathrm{mg} / \mathrm{kg} \mathrm{bw}$ (grey line), sleep disturbances are observed in adults. The Icelandic and Swedish intake estimations are based on actual consumption data, while the Danish and Norwegian intake estimations are based on the assumption that cola drinks comprise $60 \%$ of the total soft drink consumption. Finland did not have relevant data in this age group.

Figure 13 shows that most children in the age group 4-6 years in the Nordic countries are exposed to caffeine from cola drinks at levels below the LOAEL at $2.5 \mathrm{mg} / \mathrm{kg}$ bw/day, which is associated with jitteriness/anxiety. Approximately $25-60 \%$ of the $4-$ to 6 -year-olds are below the NOEL at $0.3 \mathrm{mg} / \mathrm{kg}$ bw/day for all effects of caffeine identified in chapter 2.5.9. However, approximately $20 \%$ are above the level (LOEL) were one might expect tolerance development and withdrawal symptoms. 


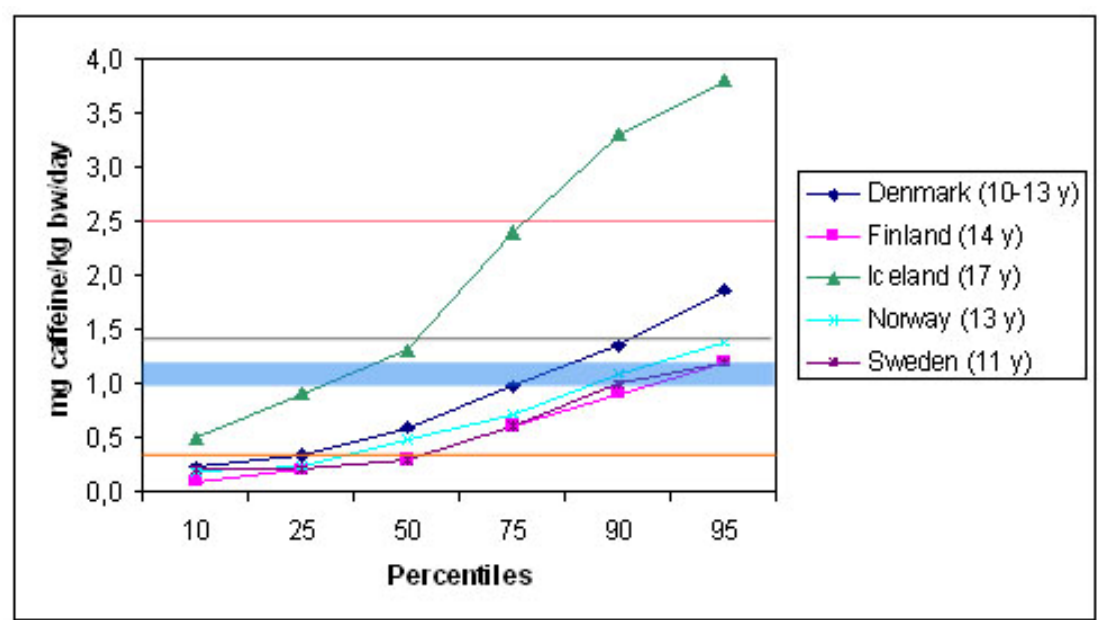

Figure 14. Caffeine exposure ( $\mathrm{mg} / \mathrm{kg}$ bw/day) from cola drinks in 11- to 17-year-olds in the Nordic countries (consumers only) compared with the threshold values suggested in the hazard characterisation (chapter 2.5.9). The (blue) area between 1 and $1.25 \mathrm{mg} / \mathrm{kg} \mathrm{bw}$ indicates the range where effects, i.e. withdrawal symptoms, can be observed. The (orange) line at $0.3 \mathrm{mg} / \mathrm{kg} \mathrm{bw}$ indicates the NOEL. At $1.4 \mathrm{mg} / \mathrm{kg}$ bw (grey line), sleep disturbances are observed in adults. The (red) line at $2.5 \mathrm{mg} / \mathrm{kg}$ bw denotes the effect level (LOAEL) for anxiety. The Finnish, Icelandic and Swedish intake estimations are based on actual consumption data, while the Danish and Norwegian intake estimations are based on the assumption that cola drinks comprise $60 \%$ of the total soft drink consumption.

Figure 14 shows that the caffeine intake among Icelandic adolescents (approx. 25\%) exceeds the LOAEL at $2.5 \mathrm{mg} / \mathrm{kg}$ bw/day for anxiety, and the whole group of Icelandic adolescents appears to have an intake above the NOEL at $0.3 \mathrm{mg} / \mathrm{kg}$ bw/day for all effects. About $50-90 \%$ of the teenagers from the other Nordic countries exceed the NOEL. Approximately $40 \%$ of the Icelandic and $10-25 \%$ of the teenagers from the other Nordic countries appear to have an intake associated with tolerance development and withdrawal symptoms. As emphasised in chapter 3.8, the comparison of the caffeine intake between Icelandic and the other Nordic adolescents must be interpreted with some caution as the Icelandic teenagers are 3-6 years older than the other participants. The true percentage exceeding the threshold values described in chapter 2.5.9 are probably somewhat higher, since caffeine from tea and coffee consumption has not been included in the estimations. 



\section{Conclusions and recommendations}

Caffeine is a widely consumed drug even among children, who mainly are exposed through the consumption of cola drinks and cocoa-containing drinks and foods. The main molecular mechanism of action is its inhibitory effect on the adenosine receptors, which are found in many tissues including the brain. Caffeine can induce tolerance and upon withdrawal, unpleasant symptoms such as headache, reduced awareness and other may be experienced. A major difference between children and adults is in caffeine clearance from the body. Up to about one year of age the clearance is extremely slow, whereas from about one year and up to about 12 years of age caffeine clearance is slightly higher than in adults. It should be noted that the inter-individual variation is quite large both among children as well as among adults.

Although there is a striking lack of quantitative data on the effect of caffeine in children and adolescents, the project group identified, through literature studies, several biological effects of low level caffeine exposure, such as tolerance development, withdrawal symptoms and anxiety and jitteriness. For tolerance development NOEL- and LOEL-values of 0.3 and $1.0-1.3 \mathrm{mg} / \mathrm{kg}$ bw respectively, were established, whereas a LOAEL for anxiety and jitteriness was identified at an intake of 2.5 $\mathrm{mg} / \mathrm{kg}$ bw. Although it is known that caffeine can induce sleep disturbances in children, no studies in children with this endpoint were identified. It was noted that in non-habitual caffeine consuming adults, sleep disturbance was induced at a very low intake (in the same range as that inducing tolerance development).

Caffeine-containing soft drinks are the main source of caffeine in children and adolescents. Based on dietary surveys among children aged 4-6 years in the Nordic countries, in consumers only, the caffeine exposure varies considerable, the $50^{\text {th }}$ percentile being about 0.3 to $0.5 \mathrm{mg} / \mathrm{kg}$ bw per day and the $95^{\text {th }}$ percentile about 1.0 to $1.7 \mathrm{mg} / \mathrm{kg}$ bw per day. Among teenagers, the Icelanders have the highest consumption of soft drinks among the Nordic countries. The high overall consumption is reflected in the cola consumption among teenagers, being twice as high as in the other Nordic countries at the $50^{\text {th }}$ percentile and four times as high at the $95^{\text {th }}$ percentile. Ten percent of Icelandic 17-year-olds drink more than 1.5 litres of cola per day (equivalent to $200 \mathrm{mg}$ caffeine/day or $>3$ $\mathrm{mg}$ caffeine per $\mathrm{kg}$ bw per day), while the high-consumers among the youngsters in the other Nordic countries rarely exceed 0.5 litres per day (equivalent to $50 \mathrm{mg}$ caffeine or $1 \mathrm{mg}$ per $\mathrm{kg}$ bw per day). Among con- 
sumers only, the median intake was around 0.3 to $0.6 \mathrm{mg} / \mathrm{kg}$ bw per day in Denmark, Finland, Norway and Sweden, whereas it was around 1.3 $\mathrm{mg} / \mathrm{kg}$ bw per day in Iceland. However, the age groups are not directly comparable. Furthermore, in neither of these intake estimates, caffeine from coffee, tea and chocolate were included. Thus, the true caffeine exposure is probably higher than stated above in all groups above the $50^{\text {th }}$ percentile, particularly among teenagers.

As far as our consumption data allows us to conclude, the exposure to caffeine from caffeine containing soft drinks among Nordic children 4-6 years is below the NOEL for tolerance development for approximately $50 \%$ of the children. The highest $10 \%$ of young consumers exceed the level where tolerance may develop. Including other sources of caffeine these figures might be slightly higher.

Many Nordic teenagers have an intake of caffeine that can be associated with tolerance development and withdrawal symptoms, while approximately $20 \%$ of the teenagers might be exposed to levels of caffeine from caffeine-containing soft drinks inducing anxiety and jitteriness. Including other sources of caffeine such as chocolate, tea and coffee, these figures might be higher. There are large inter-individual differences in tolerance development and some reports indicate that a substantial fraction of teenagers might have a problem with controlling their caffeine intake (Bernstein et al. 2002).

In adults, there is a general acceptance for caffeine intake levels associated with tolerance development and withdrawal symptoms. This might, to a variable degree, also be the case among teenagers. However, such effects of caffeine are unwanted in children below the age of 12 . The Project Group therefore considers the current exposure of children in the Nordic countries to caffeine to be of concern.

\section{Recommendations}

The Project Group has identified a serious lack of data related to appearance of adverse/unwanted effects in connection with caffeine exposure in children and strongly encourages further research, particularly in children 2-12 years of age. Studies should preferably be double blind, quantitative, use biological markers of exposure and aim at establishing thresholds for various unwanted effects. They should also control for potential dietary confounders such as sugar intake. 


\section{References}

A.C.S.H. The Health Effects of Caffeine. New York: American Council of Science and Health, 1981.

Abbott PJ. Caffeine: a toxicological overview. Med J Aust 1986;145:518-21.

Aldridge A, Aranda JV, Neims AH. Caffeine metabolism in the newborn. Clin Pharmacol Ther 1979;25:447-53.

Andersson HC, Hallström H, Kihlman BA. Intake of caffeine and other methylxanthines during pregnancy and risk for adverse effects in pregnant women and their foetuses (TemaNord 2004:565). Copenhagen, Denmark: Ekspressen Tryk \& Kopicenter, 2005.

Aranda JV, Collinge JM, Zinman R, Watters G. Maturation of caffeine elimination in infancy. Arch Dis Child 1979;54:946-9.

Arnaud MJ. Products of metabolism of caffeine. In: Caffeine. Perspectives from Recent Research. Berlin: Springer Verlag, 1984; 3-38.

Arnaud MJ. Comparative metabolic disposition of [1-Me14C]caffeine in rats, mice, and Chinese hamsters. Drug Metab Dispos 1985;13:471-8.

Ayers J, Ruff CF, Templer DI. Alcoholism, cigarette smoking, coffee drinking and extraversion. J Stud Alcohol 1976;37:983-5.

Bach-Rojecky L. Analgesic effect of caffeine and clomipramine: a possible interaction between adenosine and serotonin systems. Acta Pharm 2003;53:33-9.

Benowitz NL. Clinical pharmacology of caffeine. Annu Rev Med 1990;41: 277-88.

Bernstein GA, Carroll ME, Crosby RD, Perwien AR, Go FS, Benowitz NL. Caffeine effects on learning, performance, and anxiety in normal school-age children. Journal of the American Academy of Child \& Adolescent Psychiatry 1994;33:407-15.

Bernstein GA, Carroll ME, Dean NW, Crosby RD, Perwien AR, Benowitz NL. Caffeine withdrawal in normal schoolage children. Journal of the American Academy of Child \& Adolescent Psychiatry 1998;37:858-65.
Bernstein GA, Carroll ME, Thuras PD, Cosgrove KP, Roth ME. Caffeine dependence in teenagers. Drug \& Alcohol Dependence 2002;66:1-6.

Berthou F, Flinois JP, Ratanasavanh D, Beaune P, Riche C, Guillouzo A. Evidence for the involvement of several cytochromes P-450 in the first steps of caffeine metabolism by human liver microsomes. Drug Metab Dispos 1991;19:561-7.

Berthou F, Ratanasavanh D, Alix D, Carlhant D, Riche C, Guillouzo A. Caffeine and theophylline metabolism in newborn and adult human hepatocytes; comparison with adult rat hepatocytes. Biochem Pharmacol 1988;37:3691-700.

Bonnet MH \& Arand DL. Caffeine use as a model of acute and chronic insomnia. Sleep 1992;15:526-36.

Branfman AR, McComish MF, Bruni RJ, Callahan MM, Robertson R, Yesair DW. Characterization of diaminouracil metabolites of caffeine in human urine. Drug Metab Dispos 1983;11:206-10.

Brown CR, Jacob P, III, Wilson M et al. Changes in rate and pattern of caffeine metabolism after cigarette abstinence. Clinical Pharmacology \& Therapeutics 1988; 43: 488-91.

Butler MA, Iwasaki M, Guengerich FP, Kadlubar FF. Human cytochrome P450PA (P-450IA2), the phenacetin Odeethylase, is primarily responsible for the hepatic 3-demethylation of caffeine and $\mathrm{N}$-oxidation of carcinogenic arylamines. Proc Natl Acad Sci U S A 1989;86:7696-700.

Callahan MM, Robertson RS, Arnaud MJ, Branfman AR, McComish MF, Yesair DW. Human metabolism of [1-methyl14C]- and [2-14C]caffeine after oral administration. Drug Metab Dispos 1982;10:417-23.

Callahan MM, Robertson RS, Branfman AR, McComish MF, Yesair DW. Comparison of caffeine metabolism in three nonsmoking populations after oral administration of radiolabeled caffeine. Drug Metab Dispos 1983a;11:211-7. 
Callahan MM, Robertson RS, Branfman AR, McComish MF, Yesair DW. Comparison of caffeine metabolism in three nonsmoking populations after oral administration of radiolabeled caffeine. Drug Metab Dispos 1983b;11:211-7.

Castellanos FX \& Rapoport JL. Effects of caffeine on development and behavior in infancy and childhood: a review of the published literature. Food Chem Toxicol 2002;40:1235-42.

Chou TM \& Benowitz NL. Caffeine and coffee: effects on health and cardiovascular disease. Comp Biochem Physiol C Pharmacol Toxicol Endocrinol 1994;109:173-89.

Chung WG \& Cha YN. Oxidation of caffeine to theobromine and theophylline is catalyzed primarily by flavincontaining monooxygenase in liver microsomes. Biochem Biophys Res Commun 1997;235:685-8.

Collins LM, Graham JW, Rouscaulp SS, Hansen WB. Heavy Caffeine Use and the Beginning of the Substance Use Onset Process: An Illustration of Latent Transition Analysis. In: Bryant KJ, Windle M, West SG, eds. The Science of Prevention. Washington: American Psychological Association, 1997; 79-99.

Comer SD \& Carroll ME. Oral caffeine pretreatment produced modest increases in smoked cocaine self-administration in rhesus monkeys. Psychopharmacology 1996; 126:281-5.

Connolly SD \& Bernstein GA. Practice parameter for the assessment and treatment of children and adolescents with anxiety disorders. J Am Acad Child Adolesc Psychiatry 2007;46:267-83.

Cornish HH \& Christman AA. A study of the metabolism of theobromine, theophylline, and caffeine in man. J Biol Chem 1957;228:315-23.

D'Ambrosio SM. Evaluation of the genotoxicity data on caffeine. Regul Toxicol Pharmacol 1994;19:243-81.

Danmarks Fødevareforskning. Danskernes kostvaner 2000-2002. Søborg: 2005.

Denaro CP, Brown CR, Wilson M, Jacob P, III, Benowitz NL. Dose-dependency of caffeine metabolism with repeated dosing. Clin Pharmacol Ther 1990;48:277-85.

Dews PB, O'Brien CP, Bergman J. Caffeine: behavioral effects of withdrawal and related issues. Food Chem Toxicol 2002;40:1257-61.
Dimaio VJ \& Garriott JC. Lethal caffeine poisoning in a child. Forensic Sci 1974;3:275-8.

Dorfman LJ \& Jarvik ME. Comparative stimulant and diuretic actions of caffeine and theobromine in man. Clin Pharmacol Ther 1970;11:869-72.

Elkins RN, Rapoport JL, Zahn TP, Buchsbaum MS, Weingartner H, Kopin IJ, et al. Acute effects of caffeine in normal prepubertal boys. American Journal of Psychiatry 1981;138:178-83.

Enghardt Barbieri H, Pearson M, Becker W. Riksmaten - barn 2003. Livsmedelsoch näringsinntag bland barn i Sverige. Uppsala: Livsmedelsverket, 2006.

Eteng MU, Eyong EU, Akpanyung EO, Agiang MA, Aremu CY. Recent advances in caffeine and theobromine toxicities: a review. Plant Foods Hum Nutr 1997;51:231-43.

Finnegan D. The health effects of stimulant drinks. Nutrition Bulletin 2003;28:147-55.

Fisone G, Borgkvist A, Usiello A. Caffeine as a psychomotor stimulant: mechanism of action. Cell Mol Life Sci 2004;61:857-72.

Fredholm BB. Cardiovascular and renal actions of methylxanthines. Prog Clin Biol Res 1984;158:303-30.

Fredholm BB. Astra Award Lecture. Adenosine, adenosine receptors and the actions of caffeine. Pharmacol Toxicol 1995;76:93-101.

Fredholm BB, Battig K, Holmen J, Nehlig A, Zvartau EE. Actions of caffeine in the brain with special reference to factors that contribute to its widespread use. Pharmacological Reviews 1999;51: 83-133.

Fredholm BB, Chen JF, Cunha RA et al. Adenosine and brain function. Int Rev Neurobiol 2005; 63: 191-270.

Fuhr U, Doehmer J, Battula N, Wolfel C, Kudla C, Keita Y, et al. Biotransformation of caffeine and theophylline in mammalian cell lines genetically engineered for expression of single cytochrome P450 isoforms. Biochem Pharmacol 1992;43:225-35.

Garrett BE \& Griffiths RR. The role of dopamine in the behavioral effects of caffeine in animals and humans. Pharmacol Biochem Behav 1997;57:533-41. Gepdiremen A, Sonmez S, Ikbal M et al. Response to nimodipine in caffeineinduced neurotoxicity in cerebellar 
granular cell culture of rat pups. Pharmacol Res 1998; 38: 239-42.

Gilbert RM. Caffeine as a drug of abuse. Res Adv Alcohol Drug Probl 1976;3:49176.

Gilman AG, Goodman LS, Gilman A. The Pharmacological Basis of Therapeutics. 9th ed. New York: 1996.

Goldstein A \& Wallace ME. Caffeine dependence in schoolchildren? Experimental \& Clinical Psychopharmacology 1997;5:388-92.

Goodman \& Gilman's. The Pharmacological Basis o Therapeutics. 11th ed. McGraw-Hill, 2006.

Goris AH, Westerterp-Plantenga MS, Westerterp KR. Undereating and underrecording of habitual food intake in obese men: selective underreporting of fat intake. Am J Clin Nutr 2000;71:1304.

Graham DG. Caffeine - its identity, dietary sources, intake and biological effects. Nutr Rev 1978;36:97-102.

Grant DM, Tang BK, Kalow W. Variability in caffeine metabolism. Clin Pharmacol Ther 1983;33:591-602.

Hardy BG, Lemieux C, Walker SE, Bartle WR. Interindividual and intraindividual variability in acetylation: characterization with caffeine. Clin Pharmacol Ther 1988;44:152-7.

Haskell CF, Kennedy DO, Wesnes KA, Scholey AB. Cognitive and mood improvements of caffeine in habitual consumers and habitual non-consumers of caffeine. Psychopharmacology (Berl) 2005;179:813-25.

Heatherley SV, Hancock KM, Rogers PJ. Psychostimulant and other effects of caffeine in 9- to 11-year-old children. Journal of Child Psychology \& Psychiatry \& Allied Disciplines 2006;47:135-42.

Heatherley SV, Hayward RC, Seers HE, Rogers PJ. Cognitive and psychomotor performance, mood, and pressor effects of caffeine after 4,6 and $8 \mathrm{~h}$ caffeine abstinence. Psychopharmacology (Berl) 2005; 178:461-70.

Hering-Hanit R \& Gadoth N. Caffeineinduced headache in children and adolescents. Cephalalgia 2003;23:332-5.

Higdon JV \& Frei B. Coffee and health: a review of recent human research. Crit Rev Food Sci Nutr 2006;46:101-23.

Holmgren P, Norden-Pettersson L, Ahlner J. Caffeine fatalities--four case reports. Forensic Sci Int 2004;139:71-3.
Horger BA, Wellman PJ, Morien A, Davies BT, Schenk S. Caffeine exposure sensitizes rats to the reinforcing effects of cocaine. Neuroreport 1991;2:53-6.

Hughes JR \& Hale KL. Behavioral effects of caffeine and other methylxanthines on children. Experimental \& Clinical Psychopharmacology 1998;6:87-95.

James JE. Acute and chronic effects of caffeine on performance, mood, headache, and sleep. Neuropsychobiology 1998;38:32-41.

Juliano LM \& Griffiths RR. A critical review of caffeine withdrawal: empirical validation of symptoms and signs, incidence, severity, and associated features. Psychopharmacology (Berlin) 2004;176:1-29.

Kalow W. Variability of Caffeine Metbolism in Humans. ArzneimForsch/Drug Res 1985;35:319-24.

Kang SH, Lee YA, Won SJ et al. Caffeineinduced neuronal death in neonatal rat brain and cortical cell cultures. Neuroreport 2002; 13: 1945-50.

Kaplan GB, Greenblatt DJ, Ehrenberg BL, Goddard JE, Cotreau MM, Harmatz JS, et al. Dose-dependent pharmacokinetics and psychomotor effects of caffeine in humans. J Clin Pharmacol 1997;37:693703.

Karacan I, Thornby JI, Anch M, Booth GH, Williams RL, Salis PJ. Dose-related sleep disturbances induced by coffee and caffeine. Clin Pharmacol Ther 1976;20:682-9.

Keijzers GB, De Galan BE, Tack CJ, Smits P. Caffeine can decrease insulin sensitivity in humans. Diabetes Care 2002;25:364-9.

Kerrigan S \& Lindsey T. Fatal caffeine overdose: two case reports. Forensic Sci Int 2005;153:67-9.

Kihlman BA. Caffeine and chromosomes. Amsterdam: Elsevier, 1977.

Kinzig-Schippers M, Fuhr U, Zaigler M, Dammeyer J, Rusing G, Labedzki A, et al. Interaction of pefloxacin and enoxacin with the human cytochrome P450 enzyme CYP1A2. Clin Pharmacol Ther 1999;65:262-74.

Krebs-Smith SM, Graubard BI, Kahle LL, Subar AF, Cleveland LE, BallardBarbash R. Low energy reporters vs others: a comparison of reported food intakes. Eur J Clin Nutr 2000;54:281-7. Ladefoged O, Lam HR, Østergaard G, Nielsen E, Arlien-Søborg P. Neurotoxi- 
cology. Review of definition, methodology and criteria. Miljøprosjekt The Danish Environmental Protection Agency 1995;282:1-110.

Lambert GH, Schoeller DA, Kotake AN, Flores C, Hay D. The effect of age, gender, and sexual maturation on the caffeine breath test. Dev Pharmacol Ther 1986;9:375-88.

Lehtihet M, Sundh UB, Andersson DE. Energy drinks--dangerous or not? Cases with severe symptoms with possible connection to energy drinks--more case reports wanted. Lakartidningen 2006;103:2738-41.

Lillegaard IT, Loken EB, Andersen LF. Relative validation of a pre-coded food diary among children, under-reporting varies with reporting day and time of the day. Eur J Clin Nutr 2007;61:61-8.

Magkos F \& Kavouras SA. Caffeine use in sports, pharmacokinetics in man, and cellular mechanisms of action. Crit Rev Food Sci Nutr 2005;45:535-62.

Massey LK \& Opryszek AA. No effects of Adaption to Dietary Caffeine on Calcium Excretion in Young Women. Nutr Res 1990;10:741-7.

Moffat AC, Osselton MD, Widdop B. Clarke's Analysis of Drugs and Poisons. Pharmaceutical Press, 2004.

Moreau JL \& Huber G. Central adenosine $\mathrm{A}(2 \mathrm{~A})$ receptors: an overview. Brain Res Brain Res Rev 1999;31:65-82.

Mumford GK, Benowitz NL, Evans SM, Kaminski BJ, Preston KL, Sannerud CA, et al. Absorption rate of methylxanthines following capsules, cola and chocolate. Eur J Clin Pharmacol 1996;51:319-25.

Naqvi NH, Rudrauf D, Damasio H, Bechara A. Damage to the insula disrupts addiction to cigarette smoking. Science 2007;315:531-4.

Nawrot P, Jordan S, Eastwood J, Rotstein J, Hugenholtz A, Feeley M. Effects of caffeine on human health. Food Addit Contam 2003;20:1-30.

Nehlig A. Are we dependent upon coffee and caffeine? A review on human and animal data. Neurosci Biobehav Rev 1999;23:563-76.

Nehlig A, Daval JL, Debry G. Caffeine and the central nervous system: mechanisms of action, biochemical, metabolic and psychostimulant effects. Brain Res Brain Res Rev 1992;17:139-70.

Nicholson AN \& Stone BM. Heterocyclic amphetamine derivatives and caffeine on sleep in man. Br J Clin Pharmacol 1980;9:195-203.

Niinikoski H, Lagström H, Jokinen E, Siltala M, Rönnemaa T, Viikari J, Raitakari OT, Jula A, Marniemi J, Näntö-Salo $\mathrm{K} \&$ Simell O. Impact of repeated dietary counselling between infancy and 14 years of age on dietary intakes and serum lipids and lipoproteins: the STRIP study. Circulation 2007;116:1032-40.

Nousbaum JB, Berthou F, Carlhant D, Riche C, Robaszkiewicz M, Gouerou H. Four-week treatment with omeprazole increases the metabolism of caffeine. Am J Gastroenterol 1994;89:371-5.

Oberstar JV, Bernstein GA, Thuras PD. Caffeine use and dependence in adolescents: one-year follow-up. J Child Adolesc Psychopharmacol 2002;12:127-35.

Paluska SA. Caffeine and exercise. Curr Sports Med Rep 2003;2:213-9.

Parkinson A. Biotransformation of xenobiotics. In: Casarett and Doull, ed. Toxicology: The Basic Science of Poisons.5 ed. New York: Macmillan, 1996; 113-86.

Pollak CP \& Bright D. Caffeine consumption and weekly sleep patterns in US seventh-, eighth-, and ninth-graders. Pediatrics 2003;111:42-6.

Pollestad ML, Øverby NC, Andersen LF. Kosthold blant 4-åringer. Landsomfattende kostholdsundersøkelse. UNGKOST-2000. Oslo: Sosial- og helsedirektoratet, 2002.

Pryer JA, Vrijheid M, Nichols R, Kiggins $\mathrm{M}$, Elliott $\mathrm{P}$. Who are the 'low energy reporters' in the dietary and nutritional survey of British adults? Int J Epidemiol 1997:26:146-54.

Rall TW. Central nervous system stimulants. The xanthines. In: Gilman AG, ed. The Pharmacological Basis of Therapeutics.6 ed. London: Macmillan, 1980; 592-607.

Rapoport JL, Berg CJ, Ismond DR, Zahn TP, Neims A. Behavioral effects of caffeine in children. Relationship between dietary choice and effects of caffeine challenge. Archives of General Psychiatry 1984;41:1073-9.

Rapoport JL, Elkins R, Neims A, Zahn T, Berg CJ. Behavioral and autonomic effects of caffeine in normal boys. Developmental Pharmacology \& Therapeutics 1981a;3:74-82.

Rapoport JL, Jensvold M, Elkins R, Buchsbaum MS, Weingartner H, Ludlow 
C, et al. Behavioral and cognitive effects of caffeine in boys and adult males. Journal of Nervous \& Mental Disease 1981b;169:726-32.

Rogers PJ, Dernoncourt C. Regular caffeine consumption: a balance of adverse and beneficial effects for mood and psychomotor performance. Pharmacol Biochem Behav 1998; 59: 1039-45.

Rogers PJ, Heatherley SV, Hayward RC, Seers HE, Hill J, Kane M. Effects of caffeine and caffeine withdrawal on mood and cognitive performance degraded by sleep restriction. Psychopharmacology (Berl ) 2005; 179:742-52.

Sahin B, Galdi S, Hendrick J, Greene RW, Snyder GL, Bibb JA. Evaluation of neuronal phosphoproteins as effectors of caffeine and mediators of striatal adenosine A2A receptor signaling. Brain Res 2007;1129:1-14.

Satel S. Is caffeine addictive?--a review of the literature. Am J Drug Alcohol Abuse 2006;32:493-502.

Sawynok J. Pharmacological rationale for the clinical use of caffeine. Drugs 1995;49:37-50.

Sawynok J \& Yaksh TL. Caffeine as an analgesic adjuvant: a review of pharmacology and mechanisms of action. Pharmacol Rev 1993;45:43-85.

Schenk S, Valadez A, Horger BA, Snow S, Wellman PJ. Interactions between caffeine and cocaine in tests of selfadministration. Behavioural Pharmacology 1994;5:153-8.

Schmidt B, Roberts RS, Davis P, Doyle LW, Barrington KJ, Ohlsson A, et al. Long-term effects of caffeine therapy for apnea of prematurity. N Engl J Med 2007;357:1893-902.

Simell O, Niinikoski H, Rönnemaa T, Lapinleimu H, Routi T, Lagström H, Salo P, Jokinen E \& Viikari J. Special Turku Coronary Risk Factor Intervention Project for Babies (STRIP). Am J Clin Nutr 2000;72:1316S-1331S.

Slikker Jr W \& Chang LW. Handbook of Developmental Neurotoxicology. Academic Press, 1998.

Somani SM, Khanna NN, Bada HS. Caffeine and theophylline: serum/CSF correlation in premature infants. J Pediatr 1980;96:1091-3.

Stavric B. Methylxanthines: toxicity to humans. 2. Caffeine. Food Chem Toxicol 1988;26:645-62.
Steingrímsdóttir L, Thorgeirsdóttir H, Olafsdóttir AS. Hvad borda Islendingar? The diet of Icelanders: dietary survey of the Icelandic Nutrition Council 2002. Reykjavik, Rannsóknir Manneldisráds Islands V, 2003.

Strain EC, Mumford GK, Silverman K, Griffiths RR. Caffeine dependence syndrome. Evidence from case histories and experimental evaluations. JAMA 1994;272:1043-8.

Sved S, Hossie RD, McGilveray IJ. The human metabolism of caffeine to theophylline. Res Commun Chem Pathol Pharmacol 1976;13:185-92.

Svenningsson P, Le Moine C, Fisone G, Fredholm BB. Distribution, biochemistry and function of striatal adenosine A2A receptors. Prog Neurobiol 1999;59: 355-96.

Tang BK, Grant DM, Kalow W. Isolation and identification of 5-acetylamino-6formylamino-3-methyluracil as a major metabolite of caffeine in man. Drug Metab Dispos 1983;11:218-20.

Tassaneeyakul W, Birkett DJ, McManus ME, Tassaneeyakul W, Veronese ME, Andersson T, et al. Caffeine metabolism by human hepatic cytochromes P450: contributions of $1 \mathrm{~A} 2,2 \mathrm{E} 1$ and $3 \mathrm{~A}$ isoforms. Biochem Pharmacol 1994;47:1767-76.

Tavani A \& La Vecchia C. Coffee, decaffeinated coffee, tea and cancer of the colon and rectum: a review of epidemiological studies, 1990-2003. Cancer Causes Control 2004;15:743-57.

Tennant FS, Jr. \& Detels R. Relationship of alcohol, cigarette, and drug abuse in adulthood with alcohol, cigarette and coffee consumption in childhood. Preventive Medicine 1976;5:70-7.

Tórsdóttir I \& Gunnarsdóttir I. Hvad borda Islensk born og unglingar? The Diet of Icelandic 9- and 15-year-old children and adolescents: Dietary survey of Unit for Nutrition Research 2003-2004. Rannsoknastofa I næringarfrædi vid Haskola Islands og Landspitalahaskolasjukrahus, 2006.

Trang JM, Blanchard J, Conrad KA, Harrison GG. The effect of vitamin $\mathrm{C}$ on the pharmacokinetics of caffeine in elderly men. Am J Clin Nutr 1982;35:487-94.

Turley KR \& Gerst JW. Effects of caffeine on physiological responses to exercise in young boys and girls. Med Sci Sports Exerc 2006;38:520-6. 
Umhverfisstofnun Islands. Mælingar a koffini i drykkjum a islenskum markadi. UST-R-2007:1. Umhverfisstofnun, Reykjavik, 2006.

Verheijen. Estimation of caffeine intake from beverages in Iceland. Food Addit Contam 2008; In press.

VKM. Impact on health when sugar is replaced with intense sweeteners in soft drinks, 'saft' and nectar. ISBN 978-828082-201-7. Norwegian Scientific Committee for Food Safety, Oslo, 2007.

Von Borstel R. Biological effects of caffeine. Metabolism Food Technol 1983;37:40-6.

Walsh JK, Muehlbach MJ, Humm TM, Dickins QS, Sugerman JL, Schweitzer PK. Effect of caffeine on physiological sleep tendency and ability to sustain wakefulness at night. Psychopharmacology (Berl ) 1990;101:271-3.

Weinstein D, Mauer I, Solomon HM. The effects of caffeine on chromosomes of human lymphocytes. In vivo and in vitro studies. Mutat Res 1972;16:391-9.

WHO. Principles for evaluating health risks in children associated with exposure to chemicals. WHO, 2006.
Williams JH \& Ross L. Consequences of prenatal toxin exposure for mental health in children and adolescents: a systematic review. Eur Child Adolesc Psychiatry 2007;16:243-53.

Yasuhara M, Levy G. Caffeine as a potential risk factor for theophylline neurotoxicity. J Pharm Sci 1988; 77: 745-7.

Yesair DW, Branfman AR, Callahan MM. Human disposition and some biochemical aspects of methylxanthines. Prog Clin Biol Res 1984;158:215-33.

Zevin S \& Benowitz NL. Drug interactions with tobacco smoking. An update. Clin Pharmacokinet 1999;36:425-38.

Zhi JG, Levy G. Effect of chronic caffeine administration on theophylline concentrations required to produce seizures in rats. Proc Soc Exp Biol Med 1990; 193: 210-3.

Øverby NC, Andersen LF. Ungkost 2000. Landsomfattende kostholdsundersøkelse blant elever i 4.- og 8. klasse i Norge. Oslo: Sosial- og helsedirektoratet, Avdeling for ernæring, 2002.Optional summaries 


\section{In Norwegian}

En risikovurdering av koffein basert på inntaket hos barn og ungdom i de nordiske landene er gjennomført. Effekter på sentralnervesystemet er spesielt i fokus. Den følger standardoppsettet for risikovurderinger og starter med en fareidentifikasjon/farekarakterisering av koffein, etterfulgt av eksponerings- og risikokarakterisering. En oversikt over inntaksdata for matvarer som inneholder koffein, spesielt koffeinholdige drikker konsumert blant barn og ungdom i de nordiske landene, er presentert i eksponeringskarakteriseringen.

I løpet av de siste tiårene har inntaket av koffeinholdige drikker, spesielt coladrikker og såkalte "energidrikker" økt betydelig. Flere alvorlige episoder, som følge av ekstreme inntak av drikker med stimulerende effekt ("energidrikker") i kombinasjon med alkohol, har gjort myndighetene og det vitenskapelige miljøet oppmerksomme på problemstillingen. Internasjonale vitenskaplige institusjoner, som verdens helseorganisasjon (WHO), EUs tidligere vitenskapelige komité for mat (SCF) og det nåværende europeiske mattrygghetsorganet (EFSA) har ikke fastsatt et akseptabelt daglig inntak (ADI) eller et øvre tolerabelt inntaksnivå for koffein.

Et regelmessig daglig inntak av koffeinholdige drikker er utbredt $i$ alle aldersgrupper over hele verden, inkludert barn, som hovedsaklig blir eksponert gjennom inntak av coladrikker og kakaobaserte matvarer. Koffein er vist å ha flere virkninger på kroppen, inklusive effekter på det kardiovaskulære systemet, økt nyreekskresjon og økt produksjon av magesaft. Siden mulige uønskede helseeffekter av koffein hos barn mest sannsynlig oppstår i sentralnervesystemet, er dette temaet spesielt vektlagt i rapporten. Koffeins viktigste molekylære virkningsmekanisme er dets hemmende effekt på adenosinreseptorer, som finnes i mange vev, også i hjernen. Selv om koffein er en av de mest studerte stoffer i mat, er de fleste studiene på mennesker utført på voksne, og vår kjennskap til effekter på barn og ungdom er begrenset.

Høy eksponering for koffein hos voksne kan gi helseeffekter som nervøsitet, engstelse, rastløshet, søvnløshet, skjelving og overfølsomhet. Koffeindosene som er forbundet med alvorlige nevrotoksiske effekter er langt over det som normalt blir konsumert. Det er mange holdepunkter for at utviklingen av nervesystemet varer fra fosterperioden og gjennom hele oppveksten, men tilgjengelig kunnskap er utilstrekkelig og tillater ikke en konklusjon vedrørende eventuelle uønskede effekter av koffein på denne utviklingen.

Blant studier av koffeins effekter på barn og ungdom er toleranse, avhengighets- og abstinenssymptomer, kognitive utførelse, atferd, nervøsitet og depresjon undersøkt. Selv om det er svært relevant, er det ikke 
funnet noen studier som spesielt har undersøkt virkningen av koffein på søvn hos barn.

Følgende punkter oppsumerer de epidemiologiske studiene som er relevante for barn:

1. De epidemiologiske og kliniske studiene viser at den vitenskaplige interessen vedrørende koffeins effekter på barn og ungdom har vært beskjeden, spesielt det siste tiåret. De fleste studiene ble utført for lenge siden, og har ikke alltid skilt mellom effektene av koffein og andre kostholdsmessige faktorer, for eksempel sukker. I noen tilfeller ble dessuten studiene utført med svært få deltagere.

2. Et samlet inntrykk fra studiene er at det er betydelige individuelle forskjeller i følsomheten for uønskede koffeinrelaterte effekter. Dette kan igjen påvirke individenes bruks- og inntaksmønster av koffeinholdige matvarer.

3. Det bør skilles mellom uønskede effekter indusert av koffeinabstinens hos konsumenter med et regelmessig inntak av koffein (abstinenssymptomer), og uønskede effekter indusert hos lavkonsumenter eller ikke-konsumenter som plutselig blir eksponert for høye doser koffein.

4. Som hos voksne, har et moderat inntak av koffein en stimulerende effekt på barn og ungdom. Høyere doser kan gi negative effekter som nervøsitet, anspenthet og engstelse, spesielt hos dem som normalt er lavkonsumenter.

5. Effekter på avhengighet og toleranseutvikling bør studeres nærmere.

6. Koffeininntaket hos barn/ungdom med problemer med engstelse, hodepine eller søvn bør undersøkes nærmere.

Selv om det er en påfallende mangel på kvantitative data av koffeins effekter på barn og ungdom, har prosjektgruppen, gjennom litteraturstudier, identifisert flere biologiske effekter ved eksponering for lave nivåer av koffein, slik som toleranseutvikling, abstinenssymptomer, engstelse og anspenthet. For toleranseutvikling ble det identifisert NOEL- og LOELverdier på henholdsvis 0,3 og 1,0-1,3 $\mathrm{mg} / \mathrm{kg}$ kroppsvekt, mens en LOAEL for engstelse og anspenthet ble identifisert ved et inntak på 2,5 $\mathrm{mg} / \mathrm{kg}$ kroppsvekt. Selv om det er kjent at koffein kan gi søvnforstyrrelser hos barn, ble det ikke funnet noen studier på barn med dette endepunktet. Hos voksne med et uregelmessig inntak av koffein ble søvnforstyrrelser indusert ved svært lave doser (i samme størrelsesorden som gir toleranseutvikling).

Det er store individuelle variasjoner både blant barn og ungdom med hensyn til hvor raskt koffein blir skilt ut av kroppen. I tillegg har barn og voksne forskjellig hastighet på omsetningen av koffein. Utskillelsen er svært lav inntil barnet er ett år gammelt. Opptil 10-12 års-alderen er utskillelsen høyere enn hos voksne. 
Inntak av koffeinholdig mat og drikke blant barn og ungdom i de nordiske landene

Koffeinholdig leskedrikker er hovedkilden til koffein blant barn og ungdom. Basert på kostholdsundersøkelser blant barn i 4-6 års alderen i de nordiske landene, varierer koffeineksponeringen blant de som har et konsum (consumers only) betydelig, 50 persentilen er ca 0,3 til $0,5 \mathrm{mg} / \mathrm{kg}$ kroppsvekt per dag mens 95 persentilen er 1,0 til 1,7 mg/kg kroppsvekt per dag. Blant de nordiske tenåringene er det tenåringene på Island som har det høyeste inntaket av leskedrikker. Deres høye samlede inntak er reflektert $\mathrm{i}$ at inntaket av coladrikker blant tenåringer er dobbelt så høyt som i de andre nordiske landene ved 50 presentilen og fire ganger så høyt ved 95 persentilen. Ti prosent av 17-åringene på Island drikker mer enn 1,5 liter coladrikker hver dag (tilsvarende $200 \mathrm{mg}$ koffein/dag eller $>3$ mg koffein per kg kroppsvekt per dag), mens høykonsumentene i de andre nordiske landene sjelden drikker mer enn 0,5 liter per dag (tilsvarende $50 \mathrm{mg}$ koffein eller $1 \mathrm{mg} / \mathrm{kg}$ kroppsvekt per dag). Blant dem som har et konsum ligger gjennomsnittsinntaket fra 0,3 til $0,6 \mathrm{mg} / \mathrm{kg}$ kroppsvekt per dag i Danmark, Finland, Norge og Sverige, mens det er ca $1,3 \mathrm{mg} / \mathrm{kg}$ kroppsvekt per dag på Island. Aldersgruppene er imidlertid ikke direkte sammenlignbare. Ingen av inntaksestimatene inkluderte koffein fra kaffe, te og sjokolade, og den faktiske koffeineksponeringen er derfor mest sannsynlig høyere enn det som ble nevnt ovenfor blant alle aldersgruppene over 50 presentilen, spesielt blant tenåringene.

Så langt vi kan tillate oss å konkludere ut i fra våre inntaksdata, er koffeineksponeringen hos nordiske barn fra 4-6 år under NOEL for toleranseutvikling for ca $50 \%$ av barna. Ti prosent av barna med høyest konsum overskrider nivået for toleranseutvikling.

Mange nordiske tenåringer har et inntak av koffein som kan forbindes med toleranseutvikling og abstinenssymptomer, mens ca. $20 \%$ av tenåringene kan bli eksponert for koffeinnivåer som kan gi nervøsitet og anspenthet. Det er store individuelle forskjeller i toleranseutvikling, og noen rapporter indikerer at en betydelig andel av tenåringer kan ha et problem med å kontrollere koffeininntaket sitt.

Hos voksne er det generelt akseptert å ha et koffeininntak som kan forbindes med toleranseutvikling og abstinenssymptomer. Dette kan, til en varierende grad, også være tilfellet blant tenåringer. Imidlertid er slike effekter av koffein ikke ønskelig hos barn under 12 år. Prosjektgruppen mener derfor at den nåværende eksponeringen for koffein hos barn i de nordiske landene er bekymringsfull. 



\section{In Finnish}

Tässä raportissa esitetään riskinarviointi lasten ja nuorten altistumisesta kofeiinille Pohjoismaissa. Raportin kirjallisuusosio keskittyy erityisesti kofeiinin vaikutuksiin keskushermostossa. Riskinarviointi on tehty standardimallin mukaisesti, ja se kattaa vaaran tunnistamisen ja kuvaamisen, altistuksen arvioinnin ja riskin kuvaamisen. Altistuksen kuvauksen yhteydessä on myös yleiskatsaus lasten ja nuorten kuluttamiin kofeiinipitoisiin ruoka-aineisiin ja etenkin virvoitusjuomiin Pohjoismaissa.

Viimeisen parinkymmenen vuoden aikana kofeiinipitoisten virvoitusjuomien, erityisesti kolajuomien ja niin sanottujen energiajuomien, kulutus on lisääntynyt huomattavasti. Liiallinen stimuloivien juomien (energiajuomat) käyttö yhdessä alkoholin kanssa on johtanut useisiin kuolemantapauksiin, jotka ovat havahduttaneet sekä viranomaiset että tiedeyhteisön. Kansainväliset toimielimet kuten Maailman terveysjärjestö (WHO), EU:n tieteellinen elintarvikekomitea (SCF) ja Euroopan elintarviketurvallisuusviranomainen (EFSA) eivät ole määritelleet kofeiinille hyväksyttävää päiväannosta (ADI) tai suurinta sallittua annosta.

Säännöllinen päivittäinen kofeiinipitoisten juomien käyttö on yleistä ympäri maailmaa kaikissa ikäryhmissä, mukaan lukien lapset, jotka altistuvat kofeiinille pääasiassa kolajuomien ja kaakaota sisältävien juomien ja ruoka-aineiden välityksellä. Kofeiini vaikuttaa kehon useaan eri kohtaan ja toimintoon kuten sydän- ja verisuonijärjestelmä, munuaiseritys ja vatsahappojen eritys. Mahdolliset kofeiinin haittavaikutukset näkyvät lapsilla todennäköisimmin keskushermosto-oireina, ja kirjallisuustarkastelussa perehdytäänkin kattavasti tähän aiheeseen. Kofeiinin pääasiallinen vaikutusmekanismi solutasolla on sen inhibitoiva vaikutus adenosiinireseptoreihin, joita on useissa eri kudoksissa aivokudos mukaan lukien. Vaikka kofeiini on yksi eniten tutkituista ruoan ainesosista, valtaosa ihmisillä tehdyistä tutkimuksista on tehty aikuisilla, minkä vuoksi tieto kofeiinin vaikutuksista lapsiin ja nuoriin on vähäistä.

Aikuisilla altistuminen suurelle määrälle kofeiinia voi ilmetä hermostuneisuutena, ahdistuneisuutena, rauhattomuutena, unettomuutena, tärinänä ja lisääntyneenä tuntoherkkyytenä. Suoranaiseen vakavaan neurotoksisuuteen liittyvät kofeiiniannokset näyttävät kuitenkin olevan paljon suurempia kuin tavallisesti nautittu määrä. Useiden eri tutkimusten tulokset osoittavat, että hermoston kehitys alkaa sikiökaudella ja jatkuu läpi nuoruuden. Tutkimustietoa ei ole riittävästi, jotta pystyttäisiin tekemään johtopäätöksiä kofeiinin haittavaikutuksista hermoston kehitykseen.

Tutkimukset kofeiinin vaikutuksesta lapsiin ja nuoriin keskittyvät toleranssiin, riippuvuuteen ja vieroitusoireisiin, kognitiiviseen suorituskykyyn ja käyttäytymiseen, ahdistukseen ja masennukseen. Kofeiinin vaiku- 
tuksia lasten uneen ei ole tutkittu, vaikka se olisikin erittäin tärkeä tutkimuskohde.

Yhteenvetona lapsia käsitelleistä epidemiologisista tutkimuksista voidaan todeta seuraavaa

1. Epidemiologiset ja kliiniset tutkimukset osoittavat, että tieteellinen kiinnostus kofeiinin vaikutuksista lapsiin ja nuoriin on etenkin viimeisen vuosikymmenen aikana ollut vaatimatonta. Valtaosa tutkimuksista on vanhoja, eikä niissä aina erotella kofeiinin vaikutuksia muista ruokavalioon liittyvistä tekijöistä kuten ruokavaliossa olevasta sokerista. Tämän lisäksi koehenkilöiden joukko on joissain tutkimuksissa ollut pieni.

2. Alttiudessa kofeiinin haittavaikutuksille näyttäisi olevan yksilökohtaisia eroja, mikä voi vaikuttaa kofeiinipitoisia ruokaaineita ja juomia käyttävien kulutustottumuksiin.

3. On erotettava toisistaan haittavaikutukset, joita kofeiinin puutos aiheuttaa säännöllisesti kofeiinipitoisia tuotteita käyttäville (vieroitusoireet), ja haittavaikutukset, kun vähän tai ei ollenkaan kofeiinia käyttävät altistuvat äkillisesti suurille kofeiiniannoksille.

4. Samoin kuin aikuisilla, kohtuullisella kofeiiniannoksella on stimuloiva vaikutus myös lapsiin ja nuoriin. Suuremmat annokset voivat aiheuttaa haittavaikutuksia kuten hermostuneisuutta, jännittyneisyyttä ja ahdistusta etenkin niillä, jotka käyttävät vain vähän kofeiinipitoisia tuotteita.

5. Lisätutkimuksia tarvitaan riippuvuudesta ja toleranssista.

6. Jos lapsella/nuorella on minkäänlaista ahdistuneisuutta, päänsärkyjä tai unettomuutta, hänen kofeiinipitoisten tuotteiden käyttönsä tulisi tarkistaa.

Vaikka kvantitatiivinen tieto kofeiinin vaikutuksista lapsiin ja nuoriin onkin erittäin puutteellista, projektiryhmä tunnisti kirjallisuuden perusteella useita matalalle kofeiinitasolle altistumisesta johtuvia biologisia vaikutuksia kuten toleranssin kehittyminen, vieroitusoireet, ahdistuneisuus ja jännittyneisyys. Toleranssin kehittymisessä määriteltiin tasoksi, joka ei aiheuta vaikutuksia (NOEL), 0,3 ja alhaisimmaksi tasoksi, jolla havaittiin vaikutus (LOEL), 1,0-1,3 mg/kg kehon painosta. Alhaisin taso, jolla havaitaan haittavaikutus (LOAEL) ahdistuneisuutena tai jännittyneisyytenä, määriteltiin annoksella $2,5 \mathrm{mg} / \mathrm{kg}$ kehon painosta. Vaikka onkin tiedossa, että kofeiini voi aiheuttaa unihäiriöitä lapsilla, aiheesta lapsilla tehtyjä tutkimuksia ei löydetty. Havaittiin, että vähän kofeiinipitoisia tuotteita käyttävillä aikuisilla unihäiriöitä aiheuttaa jo hyvinkin pieni määrä kofeiinia (samaa suuruusluokkaa kuin toleranssin kehittymistä aiheuttava määrä).

Huomattavaa ovat suuret yksilölliset erot kofeiinin poistumisnopeudessa aikuisilla ja lapsilla. Kofeiinin biotransformaationopeus on myös 
erilainen aikuisilla ja lapsilla. Noin vuoden ikään asti kofeiinin poistuminen elimistöstä on hyvin hidasta, kun taas poistumisnopeus 10-12 vuoden ikään asti on suurempi kuin aikuisilla.

Kofeiinipitoisten ruoka-aineiden ja juomien kulutus lapsilla ja nuorilla Pohjoismaissa

Lasten ja nuorten pääasiallinen kofeiinilähde on kofeiinipitoiset virvoitusjuomat. Pohjoismaissa 4-6-vuotiaille lapsille tehtyjen ruoankäyttötutkimusten perusteella kofeiinin kuluttajilla altistus vaihtelee huomattavasti: 50. prosenttipiste oli noin $0,3-0,5 \mathrm{mg} / \mathrm{kg}$ kehon painosta päivässä ja 95 . prosenttipiste oli noin $1,0-1,7 \mathrm{mg} / \mathrm{kg}$ kehon painosta päivässä. Murrosikäisistä islantilaiset kuluttivat eniten virvoitusjuomia Pohjoismaissa. Heidän korkea kokonaiskulutus heijastui myös kolajuomien kulutukseen, joka oli kaksinkertainen muihin Pohjoismaihin verrattuna 50. prosenttipisteessä ja nelinkertainen 95. prosenttipisteessä. Kymmenen prosenttia islantilaisista 17-vuotiaista juo enemmän kuin 1,5 litraa kolajuomaa päivässä (vastaa $200 \mathrm{mg}$ kofeiinia/päivä tai > 3mg kofeiinia/kg kehon painosta päivässä), kun taas eniten kolajuomia kuluttavat nuoret muissa Pohjoismaissa harvemmin kuluttavat enemmän kuin 0,5 litraa päivässä (vastaa $50 \mathrm{mg}$ kofeiinia tai $1 \mathrm{mg} / \mathrm{kg}$ kehon painosta päivässä). Kofeiinipitoisia tuotteita kuluttavien mediaanikäyttö oli noin $0,3-0,6 \mathrm{mg} / \mathrm{kg}$ kehon painosta päivässä Tanskassa, Suomessa, Norjassa ja Ruotsissa, kun taas sama arvo Islannissa oli $1,3 \mathrm{mg} / \mathrm{kg}$ kehon painosta päivässä, ikäryhmät eivät ole kuitenkaan suoraan verrattavissa. Tämän lisäksi tutkimuksessa ei huomioitu kofeiininsaantia kahvista, teestä ja suklaasta, minkä vuoksi todellinen altistus on todennäköisesti korkeampi kaikissa 50. prosenttipisteen ylittävissä ryhmissä etenkin murrosikäisillä.

Kulutustietojen perusteella voidaan sanoa, että kofeiinialtistus Pohjoismaissa noin 50 prosentilla 4-6-vuotiaista lapsista on alle tason, joka ei aiheuta havaittavaa vaikutusta. Noin kymmenellä prosentilla eniten kofeiinipitoisia tuotteita kuluttavista nuorista käyttö ylittää tason, jolla toleranssi voi kehittyä.

Vaikka vain vähemmistö (20\%) murrosikäisistä altistuu kofeiinimäärälle, joka voi aiheuttaa ahdistuneisuutta ja jännittyneisyyttä, monen nuoren kofeiininkulutukseen liittyy toleranssin kehittymisen ja vieroitusoireiden riski. Toleranssin kehittymisessä on suuria yksilökohtaisia eroja, ja jotkut tutkimukset antavatkin viitteitä siitä, että varsin merkittävällä osalla nuorista voi olla vaikeuksia hallita kofeiinipitoisten tuotteiden käyttöään.

Aikuisilla kofeiinimäärät, joiden katsotaan liittyvän toleranssin kehittymiseen ja vieroitusoireisiin, on yleisesti hyväksytty. Tämä voi jossain määrin olla asian laita myös nuorten keskuudessa. Tällaiset vaikutukset ovat kuitenkin ei-toivottuja alle 12-vuotiailla lapsilla. Tämän vuoksi pro- 
jektiryhmä toteaa, että lasten nykyinen altistustaso Pohjoismaissa on huolestuttava. 


\section{Appendix}

\section{Criteria for substance dependence in DSM-IV}

According to the DSM-IV, substance dependence is:

a maladaptive pattern of substance use, leading to clinically significant impairment or distress, as manifested by three (or more) of the following, occurring at any time in the same 12-month period:

1) tolerance, as defined by either of the following:

a) a need for markedly increased amounts of the substance to achieve intoxication or desired effect

b) markedly diminished effect with continued use of the same amount of the substance

2) withdrawal, as manifested by either of the following:

a) the characteristic withdrawal syndrome for the substance

b) the same (or a closely related) substance is taken to relieve or avoid withdrawal symptoms

3) the substance is often taken in larger amounts or over a longer period than was intended

4) there is a persistent desire or unsuccessful efforts to cut down or control substance use

5) a great deal of time is spent in activities necessary to obtain the substance, use the substance or recover from its effects

6) important social, occupation, or recreational activities are given up or reduced because of substance use

7) the substance use is continued despite knowledge of having a persistent or recurrent physical or psychological problem that is likely to have been caused or exacerbated by the substance Source: American Psychiatric Association, 1994. 